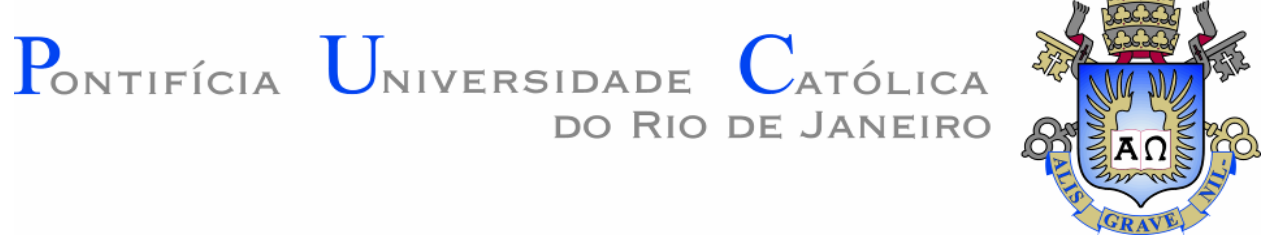

lago Gama Drumond

Brazil as a peacebuilding norm entrepreneur in Haiti and Guinea-Bissau

M.A. Thesis

Thesis presented to the Programa de Pós-Graduação em Relações Internacionais of the Instituto de de Relações Internacionais, PUC-Rio in partial fulfillment of the requirements for the degree of Mestre em Relações Internacionais

Advisor: Prof. Dr. Kai Michael Kenkel 
lago Gama Drumond

\section{Brazil as a peacebuilding norm entrepreneur in Haiti and Guinea-Bissau}

Thesis presented to the Programa de Pós-Graduação em Relações Internacionais of the Instituto de de Relações Internacionais, PUC-Rio in partial fulfillment of the requirements for the degree of Mestre em Relações Internacionais

\section{Prof. Kai Michael Kenkel} Advisor - IRI/PUC-Rio

\section{Prof. Maíra Siman}

IRI/PUC-Rio

\section{Prof. Cristina Stefan}

University of Leeds

Prof. Augusto Cesar Pinheiro da Silva

Vice Dean of Graduate Studies

Social Science Centre - PUC-Rio

Rio de Janeiro, 22 March 2019 
All rights reserved.

\section{lago Gama Drumond}

The author holds a B.A. in International Relations from the Pontifical Catholic University of Rio de Janeiro (PUC-Rio), Brazil, 2016.

Bibliographic data

Drumond, lago Gama

Brazil as a peacebuilding norm entrepreneur in Haiti and Guinea-Bissau / lago Gama Drumond ; advisor: Kai Michael Kenkel. - 2019.

130 f. : il. color. ; $30 \mathrm{~cm}$

Dissertação (mestrado)-Pontifícia Universidade Católica do Rio de Janeiro, Instituto de Relações Internacionais, 2019. Inclui bibliografia

1. Relações Internacionais - Teses. 2. Difusão normativa. 3. Contestação. 4. Statebuilding. 5. Estabilização. 6. Peacebuilding. I. Kenkel, Kai Michael. II. Pontifícia Universidade Católica do Rio de Janeiro. Instituto de Relações Internacionais. III. Título. 


\section{ACKNOWLEDGEMENTS}

Over the past two years I have had an unparalleled opportunity for academic, personal, and professional growth for which I will be eternally grateful. Having the opportunity to do my master's degree in an institution of excellence is something I will always be proud of and recognize as a privilege in my life.

First, I would like to thank my friend and advisor Kai Michael Kenkel for the teachings over the last 5 years, from undergraduate to master's degree. The conversations inside and especially outside the room were fundamental to my academic trajectory and I am very grateful for your patience and endless comprehension. I remain convinced that Brazil needs more teachers like you, committed to true education and passionate about the craft of teaching and learning together.

I also feel obliged to thank my family for all the support (financial and moral) that was given to me during the masters, but, especially, during the months of preparation of this work. I am sure that the result of not only this work, but of all my education is essentially due to the encouragement and unrestricted commitment of my father Luiz Antônio Lourenço Drumond and my mother Elizabeth Christina Dutra Gama for the education of all their sons.

To my girlfriend Beatriz Bastos Santos, I leave here my purest feeling of love and gratitude for being the person with the biggest heart I have ever known and encouraging me always, especially when I did not believe that anything would be possible. I have no doubt that I have chosen the best life partner I could have. Having you by my side is not a lucky thing, but a blessing for which I thank you every day. Your existence makes this world an infinitely happier and better place.

I remain convinced that all knowledge has a purpose only when it is shared, and fortunately I have been able to realize it in practice over the last few years through incredible teachers who have made all the effort of this master's degree worthwhile. I hereby register my most sincere thanks to professor Roberto Yamato, Marta Fernández, Paula Drumond, Jana Tabak, Monica Herz, João Nogueira, Jimmy Klausen, Isabel Siqueira, Bruno Magalhães and Luis Fernandes for the teachings and theoretical discussions and thought-provoking practices. To professor Maíra Siman I register my eternal gratitude for the lessons and discussions in the classroom and for the opportunity and confidence that were given to me by allowing 
me to be a teaching trainee in her discipline for undergraduate students. Certainly, this experience has marked my life and I will take it as an eternal lesson with me.

To all my graduate, masters and doctoral colleagues, my heartfelt thanks for the endlessness academic and personal discussions over the duration of the program. It would be impossible to thank nominally all those who were part of this trajectory, but I feel obliged to record my deepest gratitude to Pablo Fontes for his immense heart and brilliant brain for the true friendship built on this madness called postgraduate. Your future will be bright and there is no doubt about it because your present already is. To the friends Clara and Marcelle thank you for the friendship and support throughout the undergraduate and the masters.

I also feel obliged to express my immense gratitude to all the staff of the Institute of International Relations, who daily take care of the spaces destined to the classes, coexistence and help to promote well-being of all. I leave here a special thanks to Lia Gonzalez for the care and attention with the graduate students, calming us whenever possible. In the end, things always work out. Finally, I thank the Conselho Nacional de Desenvolvimento Científico e Tecnológico (CNPq) for the financial support for the elaboration of this research and the Pontifical Catholic University of Rio de Janeiro (PUC-Rio) for the exemption of the monthly fee. 


\section{RESUMO}

Drumond, Iago Gama; Kenkel, Kai Michael (Orientador). O Brasil como empreendedor normatgivo de peacebuilding no Haiti e em GuinéBissau. Rio de Janeiro, 2019, 130p. Dissertação de Mestrado - Instituto de Relações Internacionais, Pontifícia Universidade Católica do Rio de Janeiro.

A presente dissertação tem como principal objetivo analisar o engajamento do Brasil nos debates normativos sobre segurança internacional, em especial os que envolvem a temática da reconstrução estatal e a construção da paz, enquanto um agente contestador através da construção e da prática do "Brazilian Way of Peacebuilding”. Para realizar tal análise partiu-se do debate sobre normas nas Relações Internacionais para entender como uma norma surge, se consolida e pode ser contestada. Assim, para analisar essa atuação normativa do Brasil buscou-se analisar dois processos de reconstrução estatal e consolidação da paz nos quais a presença brasileira é e foi bastante significativa tanto em termos militares quanto em termos políticos: Guiné-Bissau e Haiti. A partir desses casos foi buscado entender como que o "Brazilian Way of Peacebuilding" contesta e, no limite, legitima uma visão tradicional de construção da paz. Por fim, são apresentadas as consequências dessas práticas para as normas de segurança internacional.

\section{PALAVRAS-CHAVE}

Difusão Normativa; Contestação; Statebuilding; Estabilização; Peacebuilding; Brasil 


\section{ABSTRACT}

Drumond, Iago Gama; Kenkel, Kai Michael (Advisor). Brazil as a peacebuilding norm entrepreneur in Haiti and Guinea-Bissau. Rio de Janeiro, 2019, 130p. Dissertação de Mestrado - Instituto de Relações Internacionais, Pontifícia Universidade Católica do Rio de Janeiro.

The main objective of this dissertation is to analyze Brazil's engagement in the normative debates on international security, especially those that involve the theme of Statebuilding and peacebuilding, as a contestation agent through the construction and practice of the "Brazilian Way of Peacebuilding". In order to carry out this analysis, we started with the debate on norms in International Relations to understand how a norm emerges, is consolidated and can be contested. Thus, in order to analyze this normative action in Brazil, we sought to analyze two processes of statebuilding and peacebuilding in which the Brazilian presence is and was quite significant both in military and in political terms: Guinea-Bissau and Haiti. From these cases it was sought to understand how the Brazilian Way of Peacebuilding contests and, in the limit, legitimizes a traditional vision of peacebuilding. Finally, the consequences of these practices for international security norms are presented.

\section{KEY-WORDS}

Normative Diffusion; Contestation; Statebuilding; Stabilization; Peacebuilding; Brazil 


\section{CONTENTS}

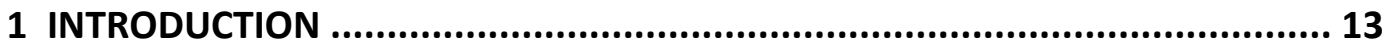

2 METHODOLOGY, HYPOTHESES AND THEORY .......................................... 17

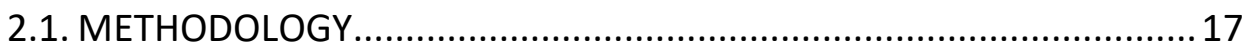

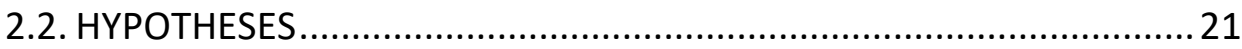

2.3. NORMS WITHIN INTERNATIONAL RELATIONS................................... 22

2.3.1. NORMS IN INTERNATIONAL RELATIONS THEORIES: A BRIEF

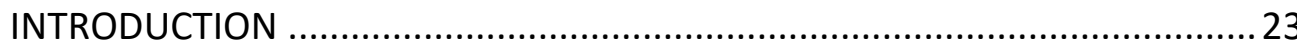

2.3.2. WAVES OF NORM DIFFUSION IN THE CONSTRUCTIVIST

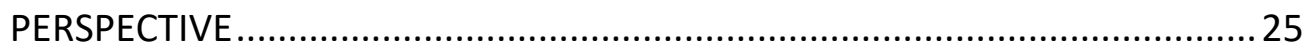

3 LIBERAL PEACE, STATEBUILDING AND STABILIZATION ............................ 45

3.1. THREE MODELS OF LIBERAL PEACE IN THE INTERNATIONAL RELATIONS AND THE KANTIAN PERPETUAL PEACE ......................................... 45

3.1.1. IMMANUEL KANT AND THE PERPETUAL PEACE ......................46

3.1.2. THE THREE MODELS OF LIBERAL PEACE SINCE THE END OF THE I

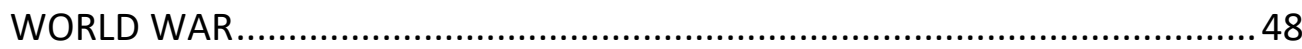

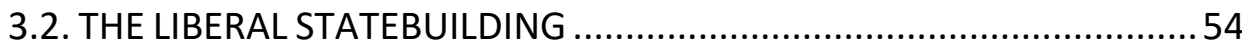

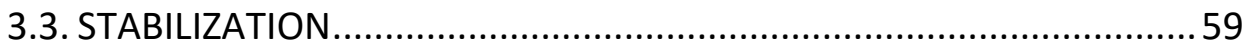

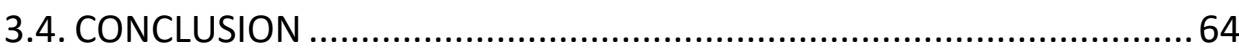

4 BRAZILIAN ENGAGEMENT AND CONTESTATION ON PEACEBUILDING..........66

4.1. BRAZILIAN NORMATIVE INITIATIVES IN THE GLOBAL LIBERAL ORDER 67

4.1.1. FROM NON-INTERVENTION TO NON-INDIFFERENCE ...............69

4.1.2. THE BRAZILIAN CONTRIBUTION TO UN PEACEKEEPING AND "THE BRAZILIAN WAY OF PEACEBUILDING" ............................................ 72

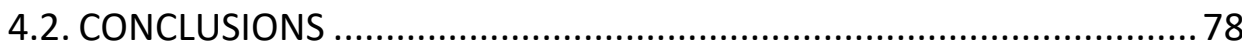

5 THE BRAZILIAN WAY OF PEACABEUILDING: THE HAITIAN EXPERIENCE........ 80

5.1. A BRIEF HISTORY OF MANY YEARS OF STRUGGLE: HAITI FROM COLUMBUS TO ARISTIDE 
5.2. THE POST-ARISTIDE SCENARIO AND THE ESTABLISHMENT OF

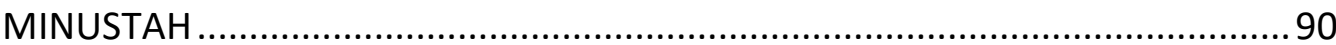

5.3. MINUSTAH AND BRAZILIAN PEACEBUILDING PRACTICES ................992

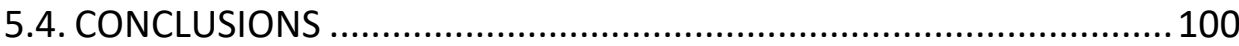

6 THE BRAZILIAN WAY OF PEACEBUILDING: THE GUINEA-BISSAU EXPERIENCE 101

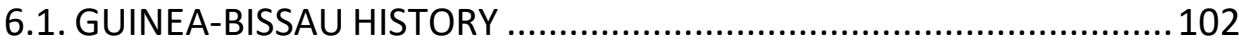

6.2. THE BRAZILIAN EXPERIENCE IN GUINEA-BISSAU ...........................107

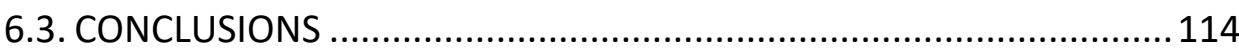

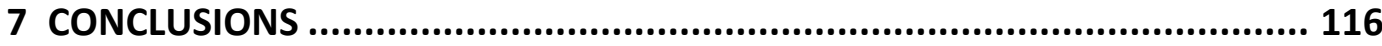

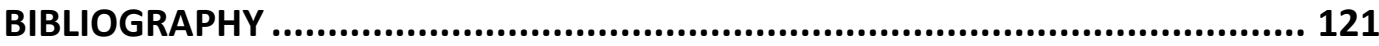




\section{LIST OF ABBREVIATIONS}

ABC - Brazilian Cooperation Agency

AU - African Union

BRABATT - Army Infantry Battalion

BRAENGCOY - Army Engineering Company

CARICOM - Caribbean Community

CBF - Brazilian Football Confederation

CISS - Critical International Security Studies

CONTBRAS - Brazilian Contingent

CPLP - Community of Portuguese Speaking Countries

FHC - Fernando Henrique Cardoso

FIFA - International Federation of Association Football

HDI - Human Development Index

HNP - Haitian National Police

ICRC - International Committee of the Red Cross and Red Crescent

IHL - International Humanitarian Law

IMF - Interim Multinational Force

IR - International Relations

MINUSCA - Mission Multidimensionnelle Intégrée des Nations Unies pour la Stabilisation en Centrafrique

MINUSTAH - Mission des Nations Unies pour la Stabilization en Haïti

MIPONUH - United Nations Civilian Police Mission in Haiti

MONUSCO - Mission de l'Organisation des Nations Unies pour la

Stabilisation en République démocratique du Congo

NATO - North Atlantic Treaty Organization

NGO - Non-Governmental Organization

OAS - Organization of American States

OAU - Organization of African Unity

PAI - African Independence Party

PAIGC - African Party for the Independence of Guinea and Cape Verde

PBC - Peacebuilding Commission

PKO - Peacekeeping Operation 
R2P - Responsibility to Protect

RwP - Responsibility while Protecting

SSC - South-South Cooperation

SSR - Security Sector Reform

TJ - Transitional Justice

UN - United Nations

UNASUR - Union of South American Nations

UNESCO - United Nations Educational, Scientific and Cultural Organization

UNIOGBIS - United Nations Integrated Peacebuilding Office in Guinea-

Bissau

UNMIH - United Nations Mission in Haiti

UNOGBIS - United Nations Peacebuilding Support Office in Guinea-

Bissau

UNSC - United Nations Security Council

UNSMIH - United Nations Support Mission in Haiti

UNTMIH - United Nations Transition Mission in Haiti

US - United States 


\section{LIST OF FIGURES AND TABLES}

Figure 1-Stabilization Theory of Change $\quad 60$

Figure 2-Stabilization Framework $\quad 61$

Table 1 - liberal peace Norm Cluster 63 


\section{INTRODUCTION}

Over the last three decades, the debates on International Security have experienced the inclusion of a series of "new" subjects in both academic discussions and in the agenda of international policymakers. This fact does not necessarily mean that these themes were not present in International Relations before the beginning of the 1990s. Many of the issues that are present in these discussions have had a significant theoretical and practical evolution. The subject and the discussions about norms in the discipline of International Relations fall exactly within this scope, having experienced a profound and important conceptual-theoretical evolution in this period.

However, it is noteworthy that various norms permeate the practices of International Relations in its most varied aspects from the foundation of the modern State with the Peace of Westphalia in 1648, according to the mainstream view of the discipline. This phenomenon is observed since, following this narrative, after the end of the Thirty Years' War, the principles of sovereignty, territoriality and non-intervention began to govern relations between states. In this sense, these norms became a part of and ruled the foundations of international politics for more than five centuries.

Another example of the fact that the norms already had considerable influence in the conduct of relations between States before the beginning of the 1990s are the norms of International Humanitarian Law (IHL) deriving from the Geneva Conventions, the first being convened by Henri Dunant in the year 1864, which would also establish the International Committee of the Red Cross and Red Crescent (ICRC). In this way, an extremely central theme for International Relations - war - started to have several aspects of its nature governed and monitored by norms. Through the Conventions signed between 1864 and 1949, hospitals and medical facilities became zones protected from hostile acts, the wounded were treated without distinction in the conflict, rules were created for the protection and custody of prisoners, and the promotion of hostility against civilians was prohibited. 
Thus, it is possible to note that no matter how many theoretical advances in norms have emerged, especially in the last thirty years, this theme has been present in modern international politics since its establishment five centuries ago. However, the new theories and advances are capable of promoting better understandings about various processes involving norms and their diffusion in the agenda and in international politics. It is precisely within this context that the present dissertation is inserted.

The present work had as its starting point the construction of a rhetoric by Brazilian diplomats, military officers and politicians that Brazil would be offering and promoting an "alternative view" for the processes of statebuilding and peace promotion, from the beginning of the decade of the 2000s through its actions in Haiti and Guinea-Bissau. This rhetoric instigated questions about the extent to which this "alternative view" presented and practiced by Brazil differed from practices considered as standard, and also in which aspects the Brazilian view had similarities with the traditional view.

These first questions led to a deeper question regarding international norms, their process of emergence, consolidation, diffusion and contestation, and Brazil's action within this agenda. It is precisely on this question that the present dissertation defines its hypotheses and general and specific objectives. Thus, the present work was based on the following research question: How does the Brazilian insertion in the debates about norms and practices of peace operations and statebuilding occurs? Being guided by this research question, this dissertation aimed to: (i) Observe how the process known as contestation in relation to the application of a given norm occurs; (ii) to discuss the notion of the liberal peace as an International Relations norm that has consequences for United Nations (UN) and statebuilding peacekeeping practices; (iii) to investigate the Brazilian role as a norm entrepreneur in its actions in MINUSTAH (Mission des Nations Unies pour la Stabilization en Haïti) and in the state reconstruction of Guinea-Bissau.

Thus, it was aimed to build a solid analysis on how normative contestation actions can, in practice, serve to legitimize an emerging norm and also to strengthen a previously consolidated norm. It should be emphasized that the present study was not intended to exhaust the subject or to propose an absolute truth about normative contestation and its effects for the discipline and practice of International Relations. However, it seeks to contribute to the evolution of this field of study through the 
engagement of theory with practice and, through this analysis, offer a possible reading for the recent Brazilian insertion in the debates and practices of international security norms.

In order to do so, I will first survey the studies involving norms in the discipline, aiming to map and introduce the theoretical field with which the dissertation intends to engage. Thus, conventional definitions and interpretations of norms will not only be presented, but will also be compared with more recent interpretations in order to present the similarities and differences between them. In addition, this approach will allow the construction, in a non-linear way, of a didactic narrative about the study of norms in the discipline, which may contribute to the advancement of the field.

Subsequently, in view of the engagement of the second chapter with the literature on norms and International Relations, the objective will be to carry out the first juxtaposition of theory and practice of the dissertation. In the second chapter the great theme called "liberal peace" in the discipline will be analyzed in the light of some interpretations of norms presented in the first chapter. Thus, it is aimed to show a series of sets of factors that make up the liberal peace not as a norm, but as a norm cluster. In this way, the problems, values and behaviors associated with this norm cluster are discussed concomitantly with the presentation of the philosophical roots of liberalism that influenced them and with the discussions involving the theory and practice of statebuilding and stabilization. The objective of proposing an analysis of liberal peace as not a single norm, but as a norm cluster is to offer a new reading for this phenomenon, which allows the interpretation of practices associated with this cluster, but also to stimulate the academic debate about how a particular phenomenon can be interpreted and instrumentalized in different ways in the discipline.

Next, the fourth chapter of this dissertation intends to contextualize the Brazilian insertion in the liberal global order and the country's historical positions regarding intervention norms and their evolution, especially after the period of redemocratization of the country after the 1980s. In addition, throughout the chapter we will also seek to present the elements that make up the so-called "Brazilian way of peacebuilding". It should be noted that the main objective of the chapter is not to deepen the Brazilian alternative to the so-called conventional peacebuilding, but rather to outline the elements that compose it. 
In order to present in practice that this Brazilian alternative vision for the processes of state reconstruction and peacebuilding is the case of Brazilian participation in Haiti, through MINUSTAH and bilateral actions, and in GuineaBissau, through its work as chair of the United Nations Peacebuilding Commission's Specific Configuration for the country, but also through bilateral action. Through these case studies the study will seek to present how, in the field, Brazilian practices perform the discourse and the precepts of the "Brazilian way" of peacebuilding. Following this approach, the impacts that these actions have on the norm cluster of the liberal peace are presented and developed in the third chapter.

It is worth mentioning that the cases used in this dissertation were chosen bearing in mind the wide and publicized Brazilian participation in both over the last fifteen years. Thus, through the analysis of the two cases, it is expected that it will be possible to obtain sufficient evidence for adequate analysis of the above research questions. In addition, the two cases are quite significant for the study of normative agency by a developing state seeking to engage in international security debates. In this sense, the case studies of Haiti and Guiné-Bissau are in line with the objective of the dissertation, since they allow the analysis of the Brazilian practices in those countries to be carried out, on how, through contestation, norms can be strengthened and legitimized before the international community.

Finally, the conclusion will synthesize the most important points of theoretical and practical argumentation. In addition, some questions will also be pointed out that may serve as a basis for future research both in the area of studies on norms and in the study of the Brazilian insertion in debates and practices of international security. 


\section{METHODOLOGY, HYPOTHESES AND THEORY}

\subsection{METHODOLOGY}

The present dissertation proposes to carry out a qualitative analysis on the normative contestation process, using a case study methodology based on the case of Brazilian participation and leadership in MINUSTAH and in statebuilding in Guinea-Bissau. In this way, bibliographical sources will be used, as well as statements from relevant Brazilian agents directly involved in the case studies to be analyzed, seeking to support the rationale of the argumentation to be developed. Therefore, the present dissertation will engage with the discussion about the socalled "practical turn" in International Relations.

This "practical turn" in the social sciences, which includes IR, intends to understand how what its called social realities - as international politics, for example - are constituted by human beings acting in and on the world. In this sense, researches based on this methodology seeks to reduce its analyzes to the basic feature of politics - practices - and study international politics through them. Thus, viewed through this lens, the major concerns of other IR approaches - war, peace, negotiations, states, diplomacy and international organizations - are sets of individual and collective practices interspersed, producing specific results.

Therefore, it is important that we first define what are practices. According to Emanuel Adler and Vincent Pouliot (2011) practices are "socially meaningful patterns of action, which, in being performed more or less competently, simultaneously embody, act out, and possibly reify background knowledge and discourse in and on the material world" (p. 4). Thus, practices are not simply "arrows" that have only a descriptive function and which connect structure to agency and vice versa, but ideational and dynamic processes that allow structures to be stable and, at the same time, able to evolve with time; further, they allow agents to reproduce and transform these structures. (ibid, p. 5).

In this way, it is also necessary to differentiate between behavior, action and practice, since however much these concepts are constantly used as 
interchangeable, they are not. In general, it is possible to say that the concept of behavior is related to the material dimension of an act in the world. One example of a behavior is an individual running aimlessly through the streets of a city. The concept of action adds the ideational dimension, which emphasizes the process of signification of the act not only at the subjective level, but also at the intersubjective level. For example, running the streets of the city to escape a thief is considered as an action once you have a meaning. In turn, practices are standardized actions that over time end up being incorporated into particular organized contexts. After this incorporation, these practices are articulated in specific types of action and are socially developed through learning and training. As an example of practice, therefore, one has the athletes who train for marathons running in the cities precisely because it is a socially structured action and that happens in a reiterated way (ibid, p. 5).

It is observed, therefore, that action is always a constitutive part of any practice. However, the inverse is not necessarily true. This fact occurs since while practices are a general class of actions that are not limited to a specific staging even though they are located in a particular social context, the action is specific and localized in time and space. Thus, the practices that interest the present dissertation are the so-called international practices, which are the socially organized activities that belong to world politics, widely interpreted. In assuming this definition it is not intended to engage in academic debates aimed at separating and differentiating comparative politics from international politics, for example. In fact, it seeks to "overthrow" in order to empirically examine how certain processes and performances are capable of producing effects of a global nature. Thus, the part of defining what can and can not be considered as an international practice is left to practitioners during their respective performances (ibid, p. 5-6).

Bearing in mind all of the above, it is necessary that at that moment the notion of practice be scrutinized not only for a better understanding of the term, but also and especially for the understanding of its use throughout the development of the present work. Thus, considering that practice, according to Adler and Pouliot (2011), has five distinct but complementary characteristics. First, it should be borne in mind that a practice is a performance, that is, the act of doing something. Secondly, the practice tends to be standardized and, consequently, ends up exhibiting certain regularities over time and space. However, it should be noted that 
the practice is not necessarily iterative, but rather the possibility of agency within the repetition. Third, practice can be considered as more or less competent in the sense that the structured dimension of practice stems not only from repetition but also, and especially, from the fact that groups of individuals tend to interpret their performance according to standards. In this way, social recognition ends up being a fundamental aspect for a practice, since it assumes the existence of an audience that evaluates it and decides whether to iterate it or not (p. 6-7).

Fourthly, a practice rests precisely on certain acquired knowledge, which incorporates, enacts and reifies everything at once. Consequently, knowledge precedes the practices and their respective intentions. In addition, it must be borne in mind that intersubjectivity is posited as intrinsically linked to performance and can only be expressed as such. Finally, it must be borne in mind that practice unites the material and discursive worlds. This fact occurs because at the same time as practices are mediated by material artifacts, they end up representing the world in specific ways, through the making of implicit assertions that things happen in a certain way (ibid, p. 7). Language, therefore, has a very important role in this construction since, according to Lene Hansen (2006), it has a great ontological importance since it is only through language that objects, states, living beings and material structures - things, of in a general way - end up receiving meaning and become endowed with a certain identity (p.16).

In general, practices are promulgated in the world and consequently can change not only the physical environment, but also the ideas people have about the world, both individually and collectively. To illustrate, in a nutshell, how this happens, the authors bring the example of the G8 meetings, as can be seen below:

"As a preliminary illustration, take the practice of international summitry - G8 annual summits, for example. These meetings of state officials constitute an international practice insofar as they conform to the five dimensions that we just laid out. First, G8 summits are performances; they consist of a number of actions and processes that unfold in real time, from the welcoming ceremony to the joint press conference through the official photography. Second, these performances are patterned from one year to the next. Although each meeting boasts its own particularities, there is much regularity in their staging, including the pecking order or the mixture of formal and informal discussions. Third, participating state officials generally exhibit a variable degree of competence as they attend the summit. The media and populations typically recognize the meaning of a clip featuring the British prime minister casually joking with the US president, for example. Fourth, much of the 
performance rests on a form of background knowledge that is bound up in practices. For instance, there is a very specific and skillful way for state officials to subtly take a little distance from the consensus forged for the official communiqué. Fifth and finally, G8 summits are both ideational and material. Participants spend a lot of time publicly and privately talking about their meetings in order to represent preferences and policies. To do so, they make use of a variety of materials - conference rooms, ceremonial artifacts, the Internet, note exchanges with sherpas, etc" (Adler; Pouliot, 2011, p. 8).

Christian Bueger and Frank Gadinger (2015) corroborate this understanding by arguing that:

"In seeing "practices" as the stuff that drives the world and makes it "hang together," the everyday practices of diplomats, terrorists, environmentalists, or financial analysts become the object of investigation. Focusing on them allows us to better understand dynamics of order and change" (p. 1).

In this context, adopting an analysis methodologically based on practical theory, implies emphasizing the process, developing a description of knowledge as action, valuing the collective knowledge, recognizing the materiality of practice, embracing the multiplicity of orders and working with a performative understanding of the world (ibid, p. 2).

Since practices are also considered as "embodied", they are materially mediated through human bodies and these bodies internalize practices. It means that practices are what actors do in and on the world. In this context, they are the common way of doing things and are produced by the repetitive interaction between members of a social group. So, practices are a kind of social artefact always linked to a collective and the products of social structures. In sum, they are acquired through the processes of socialization, exposure, imitation and symbolic relationships (Bueger; Gadinger, 2014, p. 19; Hopf, 2010, p. 548; Navari, 2011, p. 614). However, it is not to say that practical turn adopts a structuralist approach since agency is a key-element on its conception of world as practices are capable of not only constraining actors but also enabling them.

In this way, it is observed that the definition of practice presented by Emanuel Adler and Vincent Pouliot (2011) is truly open to interpret events of politics and International Relations by this lens. Precisely for this reason, it was decided to use the present methodology in the elaboration of the analysis to be carried out in the dissertation, which aims to analyze how actions are impacted and impact international norms. 
Through the methodology presented above, the objective is to present, in practice, how the "Brazilian way of peacebuilding" is influenced and, at the same time, influences international security norms. In this sense, Brazilian practices in the United Nations, Haiti and Guinea-Bissau will be tools used to understand these impacts these impacts. There is therefore no intention to perform a specific analysis of a specific point of these practices, but rather to observe its general characteristics that will support analysis of the hypotheses that will be tested.

It is also important to note that practices theories are a heterogeneous set of approaches and classifying all of them into a and classifying them within a single meaning is problematic. We have full knowledge of this issue, but we do not intend to be involved in this debate since this dissertation does not have this objective. However, throughout the present work when the idea of practical theory is used and referenced it is done precisely bearing in mind the concept presented here.

\subsection{HYPOTHESES}

As already explained in previous pages, this work aims to answer the following question How does the Brazilian insertion in the debates about norms and practices of peace operations and statebuilding occur? The choice of a "how" question occurred because the analysis to be carried out does not start from a given reality, in contrast to "why" questions. However, it should be emphasized that, although the main objective of this dissertation is not to explain the reasons for Brazilian engagement in the debates about norms and practices of peacekeeping and statebuilding, the reasons may be mentioned and pointed out throughout the text to better support the main analysis.

In this sense, therefore, taking into account everything that was exposed previously the present work will have as main hypotheses:

(a) The Brazilian performance in the normative and practical engagements of peace operations and statebuilding occurs through an action of contestation in relation to the application of the norm;

(b) The liberal peace can be considered not only as a single norm, but as a set of behaviors, values and practices that constitute a complex and influential norm cluster in international politics and; 
(c) Through the Brazilian contestation regarding the application of the liberal peace norm cluster in the cases of Guinea-Bissau and Haiti, the liberal peace norm cluster itself was strengthened and it was promoted the inclusion of stabilization operations in its set of practices.

\subsection{NORMS WITHIN INTERNATIONAL RELATIONS}

The literature within the field of International Relations shows a great predominance of the Realist perspective. Although this perspective has lost momentum after the end of the Cold War, its influence still governs several debates within the discipline, being, until the present day, the mainstream of the area. However, after the fall of the Berlin Wall and the end of the Soviet Union, there was the so-called discipline expansion and the emergence of so-called Critical International Security Studies (CISS), which has questioned and continues to question the paradigms of the realistic perspective.

In addition, the literature on the production and diffusion of norms within the discipline of International Relations (IR) has gained more space and more and more theorists have and currently are engaged in this discussion. However, one should bear in mind that the discussion and role of norms within International Relations theories did not arise after the end of the Cold War. Although they were marginal in the debates during this period, discussions about norms have always been present in the most diverse theories of the discipline (Klotz, 1995, p. 13).

Within this context, the debate on norms in the IR discipline has shown a great evolution in the last three decades, making it possible to notice a series of distinct perspectives that have developed and have been developing throughout this period. In this sense, the main objective of this chapter is to present a brief literature review, such as the state of the art, on the norm studies in the discipline with the purpose of presenting the concepts and theories that will be mobilized throughout the development of the argumentation to be presented in the dissertation. Therefore, this thesis will present the studies related to normative diffusion and its "waves", from the foundation of this research agenda to the most recent studies, which deal precisely with normative contestation. In addition, we will also introduce the notion of norm clusters. 
To do so, the chapter will be organized as follows: Initially, a brief introduction on studies of norms in International Relations Theories with the intention of historically situating the debate on norms will be presented. Then, the first wave of normative diffusion will be presented, whose focus is the propagation of norms at the systemic level. After that, the second wave, which focuses on domestic effects brought about by normative diffusion, will be debated and contextualized. In the final session, the third and the still incipient, fourth wave, which focus on the different processes of normative contestation existing, will be presented as well as their differences. Also in the final session, the norm cluster theory, developed by Carla Winston (2017), will be presented.

\subsubsection{NORMS IN INTERNATIONAL RELATIONS THEORIES: A BRIEF INTRODUCTION}

First of all, it is necessary to understand that there is no single definition of what can be understood as a norm. However, much of the existing literature within social theory and IR understands a norm as a shared set of behavior patterns and identities of a particular social group that guides practices and expectations about the actors' attitudes in a given environment and social context (Jepperson; Katzenstein; Wendt, 1996, p. 54; Klotz, 1995, p. 14; Kratochwil, 1989, p. 24; Onuf, 1989, p. 84; Wendt, 1999, p. 267).

Inspired by Abbott et al.'s (2000) article on legalization in institutions, Ryoko Nakano and Jochen Prantl (2011) understand that norms are actually an institution that has three characteristics that can vary according to each norm. These are obligation, precision, and delegation. In this context, the obligation is understood as the set of legal rules that surround the actors (p. 208-209). Secondly, the existence of a particular code of conduct that is capable of monitoring, guiding and restricting the activities of the actors in a clear way, without the existence of possible ambiguities, is understood as precision. Finally, delegation is understood as the moment when there is an authorization for actors previously outside of the normative system to interpret, implement and apply the rules (Ibid, p. 209).

It is worth noting that although the two definitions of norms presented above are different, they can be understood as complementary. Thus, bearing in mind the concepts above, it is possible to summarize the concept of norms as: 
"the set of socially constructed shared values, identities and behaviors that guide the attitudes of a given individual or social group. In addition, this norm may have different levels of obligation, precision and delegation depending on the actors and the social context in which it is embedded".

Thus, this is the definition of a norm that is most commonly used in the IR studies.

Until the late 1990s and early 2000s, the study of the role of norms within IR theories was mainly based on rationalist theories such as neoliberal institutionalism and regime theory. Within the literature of these theories it is argued that the states' decision-making processes should not be taken into account in the formulation of analysis because of the assumption of the need for parsimony in the realization of credible studies (Checkel, 1999, p. 84).

Peter Katzenstein (1996) goes further and argues that the neorealist perspective must also be considered as rationalist and structuralist. Such classification occurs because, as in neoliberal institutionalism and regime theory, this perspective also assumes the capacity that the systemic structures have of affecting the instrumental rationality of the actors (p. 12).

In general, the role assumed by norms in neoliberal institutionalism, regime theory and neorealism is very limited in the explanatory processes that these theories possess. In neorealism norms are placed only as intervening variables for explanations on questions regarding the power that the states have in the international scope. Thus, this theoretical perspective has a very great focus on processes such as the balance of power and systemic causes of wars that occur in the International System due to the inexistence of a central authority and the conflict of interests between the states that act in a manner rational seeking to maximize their expectations and, in the limit, their own survival (Björkdahl, 2002, p. 11; Mearsheimer, 2001, p. 32-36; Waltz, 1979, 118-123; Waltz, 2001, p. 208-210).

Neoliberal institutionalism and regime theory maintain the same ontology present in Realist thought, where the main actors of the international system are states. Moreover, there is no question about the lack of a central authority in the system, maintaining the principle of anarchy throughout its analyzes. However, these perspectives believe that cooperation among states, through mechanisms such as institutions and regimes, is capable of mitigating the effects of anarchy and may help the maintenance of the international order, unlike neo-Realist thought. However, these perspectives assume that the convergence of preferences of the 
actors that leads to the cooperation happens through structural and rational factors, not taking into account for the analysis, therefore, the existence of a process of constitution of preferences inside states, assuming that they are given and assuming the existence of a rationality in state actions. There is thus a limitation on the role played by norms and ideational factors in the explanatory-analytical power of these perspectives. (Axelrod; Keohane, 1985, p. 228-237; Björkdahl, 2002, p. 11; Checkel, 1999, p. 84; Keohane, 1984, p. 7-10; Krasner, 1982, p. 185-186; Ruggie, 1998, p. 22-25).

The constructivist perspective was introduced to IR by Nicholas Onuf (1984) and soon a vast literature on this perspective gained space in the discipline. This perspective broadly criticizes the assumptions of rationalist perspectives and argues that identity factors and norms play an active role in shaping the interests of agents of the international system, not merely playing the role of constraining state behavior. (Checkel, 1999, p. 84).

Within this perspective, Jepperson, Katzenstein and Wendt (1996) present the idea that norms and identities are capable of producing in the field of politics. Thus, the authors argue that norms are capable of shaping the interests of national security and even the security policy of states. In addition, there is also the argument that norms shape states' identities (p. 52).

The authors then argue that changes in the identities of states directly affect their own national interests and policies. Then, the idea that international regimes and security communities can also be affected by changes in the normative structures caused by the identity configurations of the states is developed. Finally, following this line of reasoning, it is argued that state policies are affected and influenced directly by the identities, cultural structures and norms of its internal actors (Ibid, p. 52-53).

\subsubsection{WAVES OF NORM DIFFUSION IN THE CONSTRUCTIVIST PERSPECTIVE}

Jeffrey Checkel (1999) argues that the study of norms within the constructivist literature is centered on the process known as normative diffusion. Thus, this literature aims to promote explanations to understand the processes that make a given norm or set of rules "leave" a certain point in the International System 
and "arrive" at national environments and produce constitutive effects on domestic social agents in the most different levels (p. 85).

In this sense, diffusion can be understood as any process in which the prior adoption of a particular practice by an actor changes the probability of adoption by actors who have not yet adopted it. Thus, Etel Solingen (2012) argues that transnational diffusion leads to a social interaction that enables the means, agents and, in some cases, the results of transcending the existing division between the national and international environment. Moreover, it is argued that often the analyzes promoted on the processes of diffusion of norms are formulations with explanations strictly structural or based on the action of agents. As a result, Solingen believes that it is necessary to take into account four elements in the analyzes on the diffusion processes to overcome the deficiencies of the existing analyzes ( $p$. $632)$.

The first of the elements to be considered in this scope is the presence of an initial model, stimulus or trigger. Next, one must also take into account the means by which information about the initial event "travels" or not to the object of study. It should also be studied the social agents affected positively or negatively by the initial stimulus and how they affect the diffusion trajectory to other destinations. Finally, it is necessary to study the results that allow the proper discrimination between the most distinct and possible degrees of diffusion and equilibrium resulting from the process (Ibid, p. 632).

Etel Solingen also identified that the work of James March and Johan Olsen (1998) on the institutional dynamics of international political orders also brings important contributions on how the process of normative diffusion takes place (Ibid, p. 634-635). Thus, 4 (four) scenarios can be used to understand the normative and instrumental logics of the diffusion process as it follows:

“(i) Logic A dominates logic B when implications from $\mathrm{A}$ are precise whereas those of $\mathrm{B}$ are ambiguous; (ii) Logic $\mathrm{A}$ establishes the fundamental constraints of major decisions whereas logic B explains only minor refinements; (iii) Logic A may explain initial diffusion patterns whereas logic B assumes primacy subsequently (the first logic is self-limiting, the second self-reinforcing); (iv) Logic A dominates axiomatically (in line with the observer's fundamental views of the foundations of social life as instrumental or rule-based), whereas logic B is a special case or derivative of A. Understanding when these scope conditions underlie non / diffusion is another vital research frontier" (Ibid, p. 635). 
According to Amitav Acharya (2009) the theoretical production of norms within the constructivist literature can be divided into two "waves" of normative diffusion. In general terms, it is possible to say that while the first wave has as object of study the understanding of the processes of normative propagation at the systemic level, while the second wave has as its focus the understanding of the domestic environments during the moments of changes in the local, regional and systemic norm sets (p. 9-13).

However, Simone Tholens and Lisa Groß (2015) argue that there is a third wave of diffusion studies in the literature. The studies of this wave have as objective the investigation and analyzes of the processes of contestation and localization inherent to the diffusion of normative precepts. In this way, the third wave is able to offer more in-depth explanations on the domestic side of the diffusion processes of standards in States that have just emerged from civil wars (and in moments after democratization) and on the interactive and inter-relational nature of norms. This wave, therefore, is extremely relevant and useful in understanding the attempts to change the normative structures of these transitional states, so that the analyzes made from it are not merely technical, making only the distinction between war and peace, but which are analyzes which understand the normative strategies and political motivations of the transition process (p. 251-252).

The present literature review goes even further and argues that it is already possible to speak in a fourth wave of studies on normative diffusion. This fact is possible due to a change in the ontology observed in new studies on contestation. Thus, although these studies have a similar focus to studies of the so-called third wave, there is a significant change that would justify its classification as a new wave.

\subsubsection{THE FIRST WAVE}

The first wave can be classified as a perspective called "moral cosmopolitanism". This perspective is endowed with 4 (four) specific characteristics. In the first place, the norms propagated by it are intended to be interpreted as universal or cosmopolitan. Thus, the campaigns against racism, in favor of banning chemical weapons and in favor of human rights can be taken as examples. The second characteristic of this wave points to the key actors who 
propagate the norm. In this case, the actors are transnational agents, being individual or social movements (Acharya, 2009, p. 9-10).

Third, "first wave" scholars, largely because of the influence of Sociological Institutionalism ${ }^{1}$, have a very large focus on pressure movements and proselytism on the part of transnational agents. In addition, there is the fact that the structure of global society is understood as a source of norms and normative ideas classified as "good" (Ibid, p. 10).

Fourth, this perspective tends to classify resistance to cosmopolitan norms by local agents as an immoral and illegitimate stance. Thus, the studies of the academics of this "wave" have a much greater focus on the conversion of norms into practices in the local environment than on the challenge of norms considered as universal (Ibid, p. 10).

Thus, there are 2 (two) different thoughts diffused based on the four characteristics of the first wave. The first is the belief that the diffusion of norms in the International System should be interpreted as a teaching atitude by the transnational agents to local agents. Secondly, due to the belief in the primacy of so-called "international prescriptions", there is the transnational agents' ignorance of the appeal and potential feedback of norms that are rooted in national, regional, national, and even, subnational groups (Ibid, p. 10-11).

According to Martha Finnemore (1993), the theoretical exponent of the first wave, the process of diffusion of a norm occurs, first, with the emergence of a norm. The second step in this process is the support given to the emerging standard by relevant actors and a particular International Organization. Finally, there is the internalization of the rule by the States. In order to prove its hypothesis, the author argues that the educational missions promoted by United Nations Educational, Scientific and Cultural Organization (UNESCO) reflect the emergence of a new norm created, sponsored and supported by the international community on the role that science plays in the development of modern societies and where the role of States is to coordinate the development of science. Thus, the creation of bureaucratic instruments by States with the support of UNESCO would represent the internalization of the new standard. Finally, Finnemore argues that this

\footnotetext{
${ }^{1}$ For information on Sociological Institutionalism and the role played by norms in this specific theoretical model see: FINNEMORE, Martha. Norms, Culture and World Politics: Insights from Sociology's Institutionalism. International Organization, v. 50, n. 2, 1996, p. 325-347.
} 
internalization is motivated not by local characteristics of the states, but by external actors (p. 565-566).

This process is subsequently better presented and discussed in the article by Martha Finnemore and Kathryn Sikkink (1998) "International Norms Dynamics and Political Change". The authors present what they call the "life cycle" of a norm, consisting of 3 (three) stages: The emergence of a norm; the acceptance of this norm (called normative cascade) and; its internalization (p. 895).

In the first step we have the persuasion made by norm entrepreneurs ${ }^{2}$ to convince the leading actors in the diffusion process of the need to adopt a new norm. Thus, there is the emergence of a new norm. Next, there is the acceptance of this norm by the leading actors, in a tipping point, and, as a consequence, there is the imitation of the attitude of acceptance by less powerful actors, as a way to maintain the legitimacy before the other actors, in the normative cascade. Finally, we have the internalisation of the norm by the agents and it is taken as accepted and correct and no longer be object of debate (Ibid, p. 895-896).

Thus, in the process advocated by Martha Finnemore and later by Kathryn Sikkink, it can be seen that agency power in the process of creating and disseminating norms in the International System rests only with International Organizations and, to the extent, with relevant actors which are part of them. Moreover, it is also possible to say that it is a little complex theoretical model since it is a process conceived only in three steps (the emergence of a norm; its acceptance and support by leading actors and; its internalization by the other actors) and that ignores the agency power of local actors in normative processes, a fact that motivates several criticisms of the model.

On the basis of all that has been presented above, it is possible to affirm that in the perspective of "moral cosmopolitanism" exists, even implicitly, a dichotomy that considers universal norms good while local and regional norms are considered to be bad and subversive. On the basis of this, it is possible to criticize this perspective on account of determinism in the value judgment inherent in norms, whether local, regional or cosmopolitan. This occurs because there may be cases

\footnotetext{
${ }^{2}$ Recently, the discussion and distinction between norm entepreneurs and norm antipreneurs gained force in the debates within the field of International Relations. However, this work does not aim to go deeper into this issue. For further information on this subject it is recommended to read: BLOOMFIELD, Alan. Norm antipreneurs and theorising resistance to normative change. Review of International Studies, v. 42, n. 2, 2016, p. 310 - 333.
} 
where a universal standard has a negative impact on a specific local reality and, at the same time, a regional standard produces a positive effect for the local societies covered by the norm in question.

\subsubsection{THE SECOND WAVE}

Unlike the first wave that has a large focus on the systemic structure, the second wave studies aim to understand the role of structures, thoughts, political agents and other domestic variables in the process of normative change (Acharya, 2009, p. 11-12). In this sense, it is important to emphasize that there are a series of processes, developed theoretically by several authors, that can be framed within this "wave" of academic production on international norms. Among the most relevant and widely disseminated processes in the literature on the subject one can highlight two: Framing and Grafting.

According to Rodger Payne (2001), the framing process can be understood as a central element for the success of a persuasion in the diffusion of norms. It is through this process that one has the interpretation of a specific context and that one has the capacity to indicate the behavior more appropriate for the context. The process of framing itself takes place when there is the search for the legitimation of a given normative order through construction based on one or more resonant norms ${ }^{3}$ (p.39). In this way, it is possible to say that in this process we have the production of a series of normative connections that, in the limit, make the new normative order similar to the old normative order through which it had its construction based.

In the view of Robert Benford and David Snow (2000), the framing process is considered the most relevant social movement for the diffusion of norms when the transmitting agent or the adopting agent of a given norm assumes an active role in the process. Another condition in which there is great relevance for framing is precisely when there is a problem involving the conditions of compatibility and similarities between the transmitters and the adopting powers of a given norm, which are not given a priori and need to be constructed (p 627).

\footnotetext{
${ }^{3}$ A certain norm can be called resonant when it has an ideational affinity with another normative or normative framework previously accepted and diffused in a determining social environment (Keck; Sikkink 1998, p. 204).
} 
Thus, it is possible to observe that there are two ideal types of diffusion when the diffusion objects are framed to increase their resonance capacity in the target environment. The first ideal type is strategic selection, which encompasses situations in which intentional intercultural loans exist with the adopting agent taking an active role in the process, selecting and adapting aspects of the norm diffusion in the local context. The second ideal type is strategic fitting, which encompasses situations in which there is intercultural promotion, the transmitter of the norm acting actively to fit in and adapt it to the local context of the receiver (Ibid, p. 627).

According to Amitav Acharya (2009), the grafting tactic can be understood as the attempt to institutionalize a new standard through a process of association with an existing standard. The application of the same set of rejection and acceptance for both standards is therefore applied (p.13). Thus, it is important to note that unlike the framing process, grafting does not lead to the production of new meanings for a given normative order.

Despite the difference presented above, the two processes have some similarities. In this way, it is possible to say that both the grafting process and the framing process do not present any movement of reconstruction of a certain normative order, they only promote or the reinterpretation or the representation of it. In addition, any actor can promote these processes without the need for a local actor (Ibid, p.13).

In addition to the two processes presented above, there are 3 (three) more processes that, although they have been developed more recently, have gained great space within the literature on international standards and will be used throughout the present work. These are: Constitutive Localization, Subsidiarity and Circulation.

Trough the book "Whose Ideas Matter?: Agency and Power in Asian Regionalism", Acharya (2009) seeks to understand the reasons why a multilateral security organization, such as the North Atlantic Treaty Organization (NATO), was not created in the Asia in the immediate post-1945. In addition, the author also aims to explain the reasons why Asian regional institutions maintain an institutional design considered as "soft" and resist the demands for reform that emerged and grew after the end of the Cold War (p.1). 
To answer the questions made at the beginning of the book the author offers a different explanation from those offered by neorealist, neoliberal, and even constructivist theorists. The author notes that even within the constructivist perspective there are a number of explanations and answers to the questions he has made that do not take into account the regional forces of the most different natures at the expense of explanations based on the United States (US) and its interests. Thus, Acharya questions the so-called top-down perspective, valuing national and regional dynamics for the explanation of normative processes (Ibid, p. 2-3).

It is in this context of challenge to the prevailing vision and elaboration of an explanation that takes into account the local factors, therefore, that the concept of constitutive localization ${ }^{4}$ arises. In this process one must take into account the role played by local actors in the production of the norm diffusion. However, it should not be assumed that external actors are passive agents in the diffusion, but rather that local agents and their preferences play a crucial and determining role in these processes (Ibid, p.14).

It is important to note that localization can begin with reinterpretation and (re) representation of an external norm to the analyzed environment. However, the localization process goes deeper, being a process in which there is the reconstitution of an external norm to make it congruent with the local normative order. It is possible, therefore, to affirm that in the localization process the adaptive processes previously presented (framing and grafting), among others, are not treated as phenomena without any type of relation. In localization these processes are treated together within a theoretical framework that endorses the role of local agents (Ibid, p. 14).

In practical terms, localization can be defined as a process in which there is an active construction, which can take place through different mechanisms, such as discourses, framing, grafting, cultural selection, among others, of external ideas by local actors. Thus, this process has resulted in a significant development of congruence with local beliefs and practices (Ibid, p.15).

In order for the localization process of a localized external norm to exists, there are a number of factors, variables, and scenarios that influence and are determinant to the success or failure of that process. In particular, 5 (five) factors

\footnotetext{
${ }^{4}$ It is worth noting that although the process name is constitutive localization, it is often cited and explained only as a localization.
} 
stand out. The first is the local agent's perception of the possibility of using this new standard as a mechanism to strengthen its legitimacy and authority over its institutions and practices. However, it should be noted that it is possible that initially a standard is endured and even feared that it is a norm external to the local environment. Moreover, it is extremely important that the external norm to be localized does not alter the social identities existing in the local environment (Acharya, 2004, p. 248).

The second factor that favors localization is the strength that pre-existing local norms have. It is possible that there are norms that are directly related and rooted in cultural practices, beliefs, and even fundamental documents of a particular group. Thus, it can be said that these norms are considered as strong because they are an integral part of the identity of this group. As a result, external norms are unlikely to be widely accepted and diffused in this environment. Therefore, it has the conditions for constitutive localization (Ibid, p. 248).

A third condition favoring localization is the existence of credible local actors, the so-called insider proponents, with a strong discursive capacity and influence to match or even surpass proponents of external norms operating on a global level, thus stopping the acceptance of an external norm by other local agents. These insider proponents assume the role of safeguarding and disseminating standards in their local environment. These internal proponents tend to have greater success because of the credibility that the internal audience of the epistemic community gives them because of their identifications with local values and identities, unlike what happens with actors who are seen only as agents of forces and external actors. Next, there is the fourth factor that favors the localization of a norm. The presence of a strong sense of identity on the part of policy-makers combined with the well-developed perception and feeling of being unique and exceptional in their values and social interactions helps to guide the localization process (Ibid, p. 248-249).

Finally, in addition to the factors explained above, Nakano and Prantl (2011) present another important factor for the process of localization to occur. The authors argue that another factor that influences the success of the process of localization of an external norm is its compatibility with the normative framework existing in the local environment and the availability of institutional mechanisms capable of guiding the process of mutual constitution of normative congruence (p. 210). 
It is in this context that the factors that determine the success of constitutive localization processes that the so-called advocacy networks emerges (Ibid, p. 210). In this sense, it is necessary to define how they came about and what these networks are. Keck and Sikkink (1998) argue that in international politics at the end of the twentieth century the interactions between states and other diverse non-state actors begin to lengthen and deepen, forming what can be called transnational networks. Some of these networks are economic, professional or scientific networks (p.1).

Another type of transnational network is precisely the advocacy network. Thus, advocacy networks are not formed on account of professional, economic or scientific issues. They are formed by activists and relevant actors of the most different kinds, who have common values, ideas, and principles as the reason for the formation of this network (Ibid, p. 1-2).

Thus, the role of advocacy networks in the processes of norm diffusion is relevant as they are capable of shaping issues and norms so that they become understandable for the target audience, as a way to have the congruence between the national interests and international demands. Hence, advocacy networks are able to lead debates on new ideas, norms, and other types of information (Ibid, p.23). In addition, these networks also play another crucial role, namely, naming and promoting the shaming process of rule-violating governments (Nakano; Prantl, 2011, p. 210).

It is important to note that the impact and effectiveness of these advocacy networks in the diffusion process varies according to the region. This fact occurs mainly because of 3 (three) factors. The first of these is the distribution of these networks around the globe. That is, the number of advocacy networks acting in a diffusion process depends on the locality in which the diffusion process takes place and on what subject this process addresses since the distribution of these networks occurs in an uneven manner in the International System (Ibid, p. 210).

The second point to be highlighted is that the level of openness of the domestic society matters in the diffusion process of a norm. Thus, the greater are the level of openness of a particular domestic society, the greater are the probability of success of the participation of these networks in the diffusion. Finally, we have the fact that the form and interests through which the norms are implemented vary according to the case to be analyzed (Ibid, p. 210). 
It is important to note that although it does contain some similarities with the process known as adaptation ${ }^{5}$, localization is a distinct process. Acharya (2004) argues that adaptation is a generic term that can group a series of outcomes and behaviors without defined specificities. Thus, localization has a number of unique characteristics that make it a distinct and specific process. In general, it can be said that in the process of adaptation it is sought to understand how and for what reasons external elements fit in a local culture. In this way, the main characteristic of the localization, the local elements and desires responsible for the process of normative change are left out of the adaptation process. In addition, there is also the fact that in the process of adaptation the development of new cultural "wholeness" may take place based on external and local elements whereas in localization local beliefs are always responsible for the form that the new "wholeness" assumes (p. 250).

Unlike other constructivist normative processes, in localization the cognitive environment of norm takers is not erased, but rather led to congruence with external norms. In socialization ${ }^{6}$, for example, the diffusion of a norm is understood as a result of a process in which there is the adaptation of the local behavior and practices so that they are consistent with one or more external ideas. In localization, however, the process takes place by constructing a mutually constitutive relationship between the local normative order and the external norm, making external ideas simultaneously adapted to attend to local practices (Ibid, p. 251-252). Therefore, it is justified the name of the process here exposed to be constitutive localization.

It is also important to note that the localization process is a progressive normative process and is therefore not a static or regressive process. That is, local practices and beliefs are remolded together with foreign ideas in the local context constantly on a daily basis (Ibid, p. 252). In this way, the localization processes occurs at all times, not being paralyzed or regressing in the course of its occurrence.

\footnotetext{
${ }^{5}$ For detailed information on the process of adapting norms see: JOHNSON, Alastair. Learning Versus Adaptation: Explaining Change in Chinese Arms Control Policy in the 1980s and 1990s. The China Journal, n. 35, 1996, p. 27-61.

${ }^{6}$ For detailed information on the process of norm socialization see: RISSE, Thomas; SIKKINK, Kathryn. The socialization of international human rights norms into domestic practices: introduction. In: RISSE, Thomas; ROPP, Stephen; SIKKINK, Kathryn (Eds). The Power of Human Rigths: International norms and domestic change. New York: Cambridge University Press, 1999, p. 1-38.
} 
In addition to the localization process there are two other local responses to possible international norms that occur, according to Acharya. Resistance is when no new instrument is created and the status quo of both target norm and instructional model are maintained. It is quite rare, but it is possible that the so-called displacement of norm has its answer. In this response new instruments are created at the same time that the target norm is shifted and normative hierarchy is changed. In addition, a new institution, quite different from the old one appears, or the old institution undergoes quite significant modifications (Ibid, p. 253-254).

In addition to the concept of constitutive localization, Amitav Acharya (2011) also presented and developed the concept of norm subsidiarity ${ }^{7}$, a concept essentially focused on the analysis of the normative relations between certain local actors and external powers, taking into account, for this, the fear of domination of the local actors by the external powers. In addition, in subsidiarity local actors have the possibility of exporting norms constituted in their own environment to the external environment. Thus, these local norms are used to support and even broaden the reach of existing global norms as a mechanism to combat the ideas of powerful actors. Thus, normative subsidiarity also favors local autonomy in the face of a norm and external normative pressure, but with a number of differences in location (Acharya, 2011, p. 97-98).

Added to this is the fact that the process of subsidiarity supposes the existence of an ideational structure that has the power to determine a "high authority" as legitimate. This "high authority" can be an idea, an institution, or any normative/institutional apparatus that is propagated and controlled by major powers and/or hegemonic actors (Ibid, p. 101).

In this way, it is necessary to emphasize that the subsidiarity is a process that happens specifically with smaller actors and/or endowed with less power (peripherals, in general) in a certain system. This fact is due to the very definition of the term since it is the autonomy of these peripheral actors that is challenged and

\footnotetext{
${ }^{7}$ It is worth noting that there is a theoretical debate on the concept of norm subsidiarity. However, the present work does not aim to analyze the differences between the views about the concept presented by several authors. For the development of the present work it will be used the explanation presented by Amitav Acharya (2011). For more information on this debate about the concept in question see: SALTER, Mark; SEWELL, James. Panarchy and Other Norms for Global Governance: Boutros-Ghali, Rosenau and Beyond. Global Governance, v. 1, n. 3, 1995, p. 373-382; SLAUGHTER, Anne-Marie. A New World Order. Princeton: Princeton University Press, 2004.
} 
threatened by the perceptions and fears of exclusion, abuse, violence, domination and hypocrisy by strong actors of the system to be analyzed (Ibid, p. 99).

Subsidiarity can produce two effects: The challenging/resisting effect and; the supportive/strengthening effect. The first effect occurs when local actors resistance to a certain normativity of central actors and the whole institutional apparatus that they control. Thus, local actors defend the right to produce their own rules, rules and issues to be resolved without the possibility of intervention by a "high authority" (Ibid, p. 101).

The second effect of subsidiarity is precisely the support of local actors for a given common global standard. As examples of common global norms it is possible to be highlighted the principle of state sovereignty, racial equality, nonintervention, among others. This fact occurs because the local actors see these common global norms as vital for the preservation of their respective autonomies. Thus, local actors choose to create norms, based on common global normativity, since they are seen as a mechanism of resistance to the threat of more powerful actors. It is important to note that the two possible effects of the subsidiarity process can occur concomitantly (Ibid, p. 101-102).

Finally, although they are different processes and with well-defined specificities, localization and subsidiarity can be seen, in some situations, as complementary processes. Acharya (2011) points out that there is no impediment to these two normative processes occurring simultaneously. The author emphasizes that the creation of a certain norm can end up involving both processes whereas a peripheral local actor localizes a global norm at the same time that this same peripheral actor manages to make a global norm be redefined (p. 99).

\subsubsection{CONTESTATION, THE THIRD AND FOURTH WAVES, AND NORM CLUSTERS}

In addition to the two waves briefly described above, Lisa Groß and Simone Tholens (2015) argue that there is already a third wave of studies on normative diffusion and that this wave is currently emerging. It is argued, then, that the studies of this new wave have the objective of investigating and analyzing the processes of contestation and localization inherent in the diffusion of normative precepts. In general, this wave focuses on the divergent interpretations about the meaning of the 
norm itself since it is assumed that the meaning of a norm is negotiated, depending not only on the context and by which actor or set of actors it is used, but also by whom it is interpreted (p. 251-252).

In his text "The R2P and Norm Diffusion: Towards A Framework of Norm Circulation", Amitav Acharya (2013) presents the concept of norm circulation and considers it as an alternative analytical framework for the study on the creation and diffusion of norms in the international policy. To do so, Acharya uses the emergence and evolution of the Responsibility to Protect (R2P) as a case study to present and evaluate this new concept (p. 469).

Unlike moral cosmopolitanism, the proposal for the norm circulation means the creation and diffusion of norms as a two-way process. It can be said that the process of norm circulation is a process that combines the ideas of constitutive localization and subsidiarity, presented previously. This occurs because it is understood that in the process in question, the localization of a particular norm and its local feedback are taken to the global level and can strengthen and defend this global norm, constituting a process of subsidiarity (Ibid, p. 469).

In this process there are 4 (four) dimensions to be observed: The sources; the contexts; the agents and; contestations and feedbacks. In this way, it should be borne in mind that norms have a wide variety of sources, which include a large number and complexity of actors. Thus, it is necessary to observe with caution the relations between these actors to do not have any bad perceptions on which entrepreneur or set of normative entrepreneurs owns the domain of the norm (Ibid, p. 469).

In order to analyze the context in which the process of circulation of a norm occurs we must keep in mind that supposedly global norms may have a regional context in their origins and influences. Therefore, it should not be assumed that global norms are simply adopted and/or adapted by local regions and actors. In relation to the actors, it is important to note which actors originate and diffuse a certain norm and how they do it. This fact deserves special attention, since it is often considered that only prominent actors can create and disseminate norms, when in fact less powerful actors are also capable of doing so (Ibid, pp. 469-470).

Finally, the contestations and feedbacks are another dimension of the process of norm circulation since it is possible to understand as agency the resistance that causes its contextualization and localization. Furthermore, it should 
be borne in mind that norms are rarely adopted equally in all localities, even if they carry with them the idea of universality, because of the different methods and means by which this norm is propagated (Ibid, p. 470).

The concept of nom circulation, then, offers a new perspective on how the diffusion of norms is given. The power of normative agency in this perspective, therefore, is quite broad, not limited itself only to relevant and powerful actors, but also including the less relevant actors and who, in other perspectives, are marginalized in the process of normative diffusion. Thus, the initiative for the diffusion of a norm can arise through powerful actors at the systemic level as well as less powerful actors who have historically been dominated (Ibid, p. 470-471).

Next, Acharya (2013) argues that regardless of who starts the process of circulation of a particular norm should be kept in mind that the existing influences are complex and multiple. In this way, other actors than those who initiated the process can influence it. Subsequently, the norm faces a period in which it can be challenged and can be traced back to multiple actors. This leads to a repatriation effect of the norm that can modify or reinforce the norm at its point of origin in the international space (p. 471).

At the same time, it is possible that local regulations from different regions on issues similar to those of the norm being disseminated be exported to the international sphere resonate in a global way. Such a resonance may cause a change in the promotion and/or definition of the most prominent norm on the subject. There is thus a process of norm diffusion at a two-way level, based on resistance, feedback from the actors and repatriation of the norm and involving several actors. Finally, the author emphasizes that despite the impression, this process does not necessarily cause a weakening of the norm, and may even promote not only its own strengthening, but also its mechanisms and enforcement and compliance monitoring (Ibid, p. 471).

Within the contestation perspective, Antje Wiener (2014) emphasizes that the validation of a norm does not happen in a simple way, as in the Finnemore and Sikkink model. While accepting the idea of the life cycle of a norm in three steps, the second step would be composed of three stages. The first step is the stabilization of the validity of the norm in a formal way by a particular political community, which may be local, regional, national or international. This step is typified as formal validation. In the second stage there is the understanding and validation of 
norms as indicators of behavior or source of social obligation by a particular group or social environment. This stage is called social recognition. Finally, the third stage is called cultural validation and is the moment in which the effective implementation of the norm by the individuals of the society, including, therefore, decision makers, state organizations, private companies and other public and private social organizations (p. 19-20).

Starting with the exploration of the notions of normative contestation, it is important to emphasize that there is no consensus within the studies of this perspective on what is the contestation and what are its results. It is possible to say that at present there are at least three major perspectives on the role of contestation in the study of norms. First, there is the idea that although the rules matter for the study of international politics, the challenge is not a research problem. The second perspective, however, believes that the contestation can be considered as a research problem, it is restricted to only a few situations and its study must take place within the scope of understanding the political solutions in order to make a norm matter. Finally, we have the current that defends that the contestation is an inherent quality of the norms (Niemann; Schillinger, 2016, p. 33-38).

It is precisely within this "third perspective" that this session aims to explore. Accordingly, Nicole Deitelhoff and Lisbeth Zimmermann (2013) argue that there are 2 (two) different types of norm contestation: (1) The contestation to the way of applying the norm; (2) contestation of the validity of the norm. Thus, contestation involving the application of norms ends up focusing, essentially, on the right of interpretation and application of a given norm in concrete social contexts. An example of this is the dispute over the application of the norm of gender equality by various actors of the international system in the last forty years, where there is a dispute over its application and not its existence. It is worth noting that this type of challenge is more common in more abstract norms and with little specificity, since it opens space for multiple interpretations. On the other hand, when the validity of the norm is disputed, it is not the different ways in which this norm can be applied or interpreted, but rather the norm itself. In this way, the discussions involving agents are based not on concrete situations, but on normative and/or moral principles of the agents themselves (p. 4-5).

The result of these contestation practices is not necessarily the weakening of the norm. The contestation process can generate its own normative power 
capable of serving as a discursive anchor in political debates to mold political alternatives that revitalize the validity of the norms for its recipients. In this way, the contestation can serve as a kind of mechanism for negotiating the demands of the contesting agents, and they may be attended to or not. However, there are limits to this possibility since if a norm is constantly challenged, there is a gradual erosion of its stability and acceptance by the agents (Ibid, p. 5).

The so-called constitutionalist approach also supports the idea that the contestation can generate benefits for the stability of the norms. To this end, it is assumed that the rules are contested by nature and, therefore, their constitution is constantly composed of an invisible contestation, fruit of the divergent interactions and ideas of the agents. This invisible challenge both structures the constitution of transnational governance and is structured by it. Thus, when there is a visible challenge, there is a strengthening of the democratic legitimacy of the norm and of the transnational governance itself, since this fact shifts public understanding of this norm to public debate. Thus, it can be argued that visible contestation is, in fact, a dispute over the meaning-in-use of a norm and happens from the moment when an emerging norm gains cultural validity in different environments (Wiener, 2004, p. 198-201; Wiener, 2007a, p. 6; Wiener, 2014, p. 19).

Commonly, the constitutionalist approach has been framed as belonging to the third wave. However, a peculiarity in the principles of this theory makes it possible to speak of classifying it as a wave different from the third wave since there is a divergence in relation to the nature of the meaning of the term norm itself. Whereas until the third where from studies on normative diffusion there was the consent that a norm can be understood as "the set of shared and socially constructed shared values, identities and behaviors that guide the attitudes of a particular individual or social group. Moreover, this norm can have different levels of obligation, precision and delegation depending on the actors and the social context in which it is inserted", there is a break in the meaning of the word. This fact occurs because when it is assumed that the norms are in a constant process of contestation it can not be assumed that there is a sharing of sets of values, identities and behaviors by a whole social group.

In this way, norms in constitutionalism are never considered to be watertight, but they are in a process of constant transformation. This fact also differentiates this approach from the approaches of the so-called third wave. While 
in the constitutionalist approach the norms are in a constant process of contestation and transformation, other approaches that deal with normative contestation accept the idea that although the norms are contested, these processes does not occur in a constant and inexhaustible way. It is therefore a reason why the constitutionalism can be considered as the representative of a fourth wave, although incipient, of studies on normative diffusion.

In short, it is possible to say that the contestation is an inherent phenomenon not only to the diffusion of norms in the International System, but also to the constitution of the System itself. Thus, there are 2 (two) forms of this phenomenon to manifest: (1) In an invisible way - when there are interactions and disputes inherent in the daily life of agents within a given normative context and; (2) visibly - when these interactions become public and the subject of political debates about meanings-in-use by agents in the normative context. Therefore, the effects of a contestation to the acceptance, validation, and stability of a standard can be both positive and negative. The differentiation between the positive and negative effects occurs through the intensity and the support that the response receives from the agents. In this way, it is not only plausible but factual that a contestation manages the strengthening and helps in the establishment of a certain norm since that fact causes the need for public debate about it and also makes possible its improvement in the normative level (in its validity) as well as in the practical plan (in its way of application). At this point, it should be noted that these findings are valid for both the third and fourth generation approaches.

\subsubsection{THE DUAL QUALITY OF NORMS AND NORM CLUSTERS}

The assumption that norms have a dual quality (they are both structuring and socially constructed through interaction in a context - they are both stable and flexible), as argue Antje Wiener (2007b, p. 49), and its constitutive characteristic cause a dilemma in the processes of normative diffusion to emerge: In the final result of all the procedures of normative diffusion the content and the object of the diffused norm vary from actor to actor. In an attempt to solve this problem, Carla Winston (2017) develops her theory about norm clusters, which is the idea that there are some collections of interrelated specific problems, behaviors and values that can be interpreted similar enough that their adopters form a family group. This 
concept retains the constitutive and constraint functions of traditional norms since a normative actor is constrained to act according with his cluster's behaviors and expectations, he is also enabled by the relative freedom of choice within the cluster to determine for himself what constitutes "appropriate behavior" in its own specific context. So, it must be noted that a certain use of meaning-in-use is tolerated by the community as long as a legitimate combination of problem, value, and behavior is chosen, and a new combination or component may be legitimized if the cluster community accepts it (p. 10-11).

Within the clusters, these problems, values and behaviors should be combined, depending on state context and/or other factors, into a multiple number of distinct, but at the same time, acceptable combinations of problems, values and behaviors. In this sense, each norm is understood to be an "appropriate" means of addressing the more general problem that originated the cluster adoption. It is important to note that no normative actor is obligated to emulate a predecessor to be recognized by the others as implementing and adopting the cluster. Norm clusters have boundaries, however they are intersubjectively formed, and are, consequently, malleable and based on the processes of innovation, discourse, and learning conducted by and between relevant actors (Ibid, p. 10).

The author then describes how the norm clusters are created as it follows:

"Norm clusters emerge, grow, and change, just as single norms have been theorized to do, and by using the same diffusion mechanisms. While adopters of a norm cluster may choose an outcome that creates either continuity or change, however, it is the latter that enables a norm cluster to exist in the first place. The key to enabling, creating, and evolving a norm cluster and its resulting variety of acceptable value-behavior combinations, as opposed to a single norm or bundle of single norms and the continuity they imply, is the ability of norm components to diffuse separately without engendering sanction. If the link between a single problem, value, and behavior is loosened, then the process of diffusion can therefore work separately on each norm component as long as the result is accepted by the community, and the intersubjective understanding of the norm cluster is adjusted to include this new outcome" (Ibid, p. 11).

Immediately after, Winston posits three ideal types of norm clusters. Firstly, there is the norm cluster consisting of a single value and a relatively narrow problem, but with a number of different behaviors. This ideal type is quite common and the Non-Proliferation Treaty (NPT) can be classified into this ideal type. The opposite configuration of this first ideal type of norm cluster also occurs. In the 
second ideal type of norm cluster a normative actor may justify a single behavior with reference to multiple related, but distinct, values. This can be read both as an attempt to please multiple audiences invested in the problem, thus gaining consensus for the adoption of the single behavior, and/or as the result of variations in framing by different norm entrepreneurs. As an example of this type of norm cluster it can be noted the existence of multiple clauses in the preamble of a certain law stating a number of different justifications for the same piece of legislation, which may in the end be quite specific in terms of institutional choice. These 2 (two) ideal types share 1 (one) common characteristic: 1 (one) problem and either 1 (one) behavior or one value (Ibid, p. 13-15).

The third ideal type of norm cluster proposed assumes the possibility of existence of multiple problems, behaviors and values within the cluster. The field of Transitional Justice (TJ), traditionally thought of as a set of norms rather than a single norm, is used by Carla Winston to exemplify this third ideal type of norm cluster. In this way, the oppression by democracy, authoritarianism, civil conflicts and IHL breaches are considered problem, while reconciliation, peace, transition, democracy, truth, rule of law, human rights and accountability are considered values and amnesty, commission, lustration, reparation and trial are considered behaviors (Ibid, p. 15-16).

To conclude, it can be said that in opposition to a set of fixed norms, in a norm cluster both continuity and change exist within a single issue. So, norm clusters offer a way to link pieces of a puzzle together, reconciliating the existence of continuity and change with respect to a whole group, exploring the potential for norm complementarity as well as conflict, and to relate multiple potential influences on diffusion and actors' own agencies in normative development (Ibid, p. 16-17). 


\section{LIBERAL PEACE, STATEBUILDING AND STABILIZATION}

In the past chapter the discussion on norms within IR was presented from a historical perspective, discussing the characteristics and processes of each "wave" of norm diffusion. It was also presented the discussion on norm clusters which represents an innovation in the norm studies. In the mainstream studies on norms the possibility of association of multiple problems, behaviors and values into a cluster was denied.

It is precisely within this context that the present chapter is framed. In this chapter it is aimed to discuss the concept of liberal peace, its evolution since the First World War and its implications in the international politics. Thus, it is argued that the liberal peace can be classified as a norm cluster with multiple problematiques, values and behaviors, according to Carla Winston's (2017) theory. To do so, the concepts of liberal statebuilding and stabilization will be presented and discussed in order to substantiate the argument.

Therefore, the present chapter is structured as it follows: First, a discussion on the history of the concept of liberal peace is done and its philosophical source of inspiration, namely the Kantian perpetual peace, is presented. Roger Mac Ginty's (2006) argument about the existence of three models of liberal peace in the history of international system is then presented. Directly thereafter, there is a discussion of statebuilding, the influence of the liberal peace theory and its influence on these processes seeking to explore the problems observed by the statebuilding practices and their correspondent behaviors. Ending the argument, stabilization operations and practices are discussed also in order to identify behaviors that can be framed within the liberal peace norm cluster. Finally, the conclusions obtained trough the development of the chapter will be synthesized.

\subsection{THREE MODELS OF LIBERAL PEACE IN THE INTERNATIONAL RELATIONS AND THE KANTIAN PERPETUAL PEACE}

The concept of liberal peace currently used in the discipline and practices of international relations not always had the same meaning since the first 
appearance of the term in the discipline. Over the years, and especially after the end of great conflicts that reached the international modern system, this term was used to represent different political strategies adopted by states and international organizations in order to promote peace with certain pre-determined characteristics and aspects.

Roger Mac Ginty (2006) argues that the dominant version of liberal peace as we know it today was invented after the end of the Cold War in 1989. Thus, the author considers that the current version has a great difference from previous versions. However, it is important to note that all post-1918 versions of liberal have some elements in common (p. 36). So, the present session aims to analyze the construction of liberal peace from its origin with the idea of perpetual peace proposed by Immanuel Kant until the influence that the post-1989 version of liberal peace has in the processes of statebuilding and stabilization carried out during that same period.

\subsubsection{IMMANUEL KANT AND THE PERPETUAL PEACE}

The founding milestone of the association between peace and democracy in the modern world comes with the publication of perpetual peace by Immanuel Kant in 1795. In the first definitive article for perpetual peace, which deals with the constitution of states, Kant (2008) defines that "the civil constitution in each state must be republican" (p.11). In addition, three fundamental points of this constitution are presented:

"The constitution founded, first, according to the principles of the freedom of the members of a society (as men); secondly, in accordance with the principles of the dependence of everyone upon a single common legislation (as subjects); and thirdly, according to the principle of equality for everyone (as citizens), it is the only one that derives from the idea of the original contract, in which all legal legislation of a people must be founded - it is the republican constitution" (ibid, p. 11. My translation).

In this context, a republican state is seen as positive since there is a tendency to create a relationship of responsibility between representatives of the State and its constituents. In addition, the presence and performance of legislators and public opinion are capable of restricting members of the executive branch from adopting policies that violate the fundamental interests of the population. However, this doesn't happen in dictatorial or absolutist regimes (Doyle, 2005, p. 464). 
The second definitive article for perpetual peace defines that international law must be based on a federation of free states. Kant emphasizes that the federation differs from a state because it doesn't verify the existence of a hierarchy between a legislature, considered superior, and an entity to be legislated, considered as inferior, as it can be observed in the configuration of the states. Thus, the federation manages to secure its very existence and to prevent wars involving States that are part of it (Kant, 2008, p. 15-19).

Michael Doyle (2012) points out that the federation should not be considered as a definitive peace treaty for the end of wars, as a world state or as a state of nations. The author points out that Kant doesn't precisely delimit how the organizational process of the federation would take place. Moreover, it is possible to say that the institutionalization of the federation was probably not considered relevant to Kant (p.26).

Finally, the third definitive article for perpetual peace addresses the need for so-called cosmopolitan law to limit itself to the conditions of universal hospitality. At this point, Kant argues that men should support each other since no human being has more right than the other on a particular place on the planet. This is because Kant defines that all men should be part of society on account of the common property right of the Earth and that it is forbidden for any men, individually, to extend this right to the infinite for himself (Kant, 2008, p. 20-22).

It is possible to say that each one of the three definitive articles for the perpetual peace of Kant has correspondence with constituent factors of the Contemporary International System, forming the so-called Kantian tripod. This relationship is presented by John O'Neal and Bruce Russett in the book "Triangulating Peace: Democracy, Interdependence, and International Organizations" (2001). In this way, Jens Meierhenrich (2007) defines that perpetual peace in the contemporary international system would be composed of the interdependence between democracy ("the republican constitution"), economic interdependence ("cosmopolitan law" and "universal hospitality") and international organizations ("federation") (p. 634). It is important to note that this kind of correspondence between perpetual peace and the contemporary international system and, consequently, the liberal peace was only possible due to the work of Michael Doyle (2012), who began to consider Kant's work as a source of inspiration, hope and policy (p.14). 


\subsubsection{THE THREE MODELS OF LIBERAL PEACE SINCE THE END OF THE I WORLD WAR}

Liberal peace began to gain a modern form with President Woodrow Wilson and his famous Fourteen Points ${ }^{8}$. Wilson's objective was precisely the formation of a new world order strictly different from the pre-1914 global order. In this way, the new world order would be characterized by explicit peace agreements, responsible and open diplomatic relations between states, control of the armaments of states, and the creation of a permanent and universal international organization aimed at guaranteeing the territorial integrity of all the states, regardless of size, in the same way (Mac Ginty, 2006, p. 38).

Following the ideas of Wilson it was created the League of Nations, which brought as a great innovation for the international system the concept of collective security, which has its legal formulation in the articles 10,11 and 16 of the Pact ${ }^{9}$. The main objective of the collective security system was to make a localized threat a direct threat to international peace. Thus, the occurrence of aggression against any state or group of states should generate an automatic response by a coalition of states that could use diplomatic, political and economic sanctions and military means to contain such aggression (Herz; Hoffman, 2004, p. 82).

Thus, in this system the States would not go to war by territories or by national interests, but only if there was some violation of international law. This belief rightly reinforces Kant's inspired idea of Michael Doyle (2012) that liberal states only wage war against non-liberal states to defend liberal and popular interests (p. 28). This is justified because in the formulation of the collective security system of the League of Nations there was a belief that the liberal states would respect international law and, consequently, would not go to war against each other.

It is important to note that although many scholars point to and focus on the issue of peace between states in Wilson's proposal precisely because of the concept

\footnotetext{
${ }^{8}$ Speech made by the President of the United States of America, Woodrow Wilson, on January 8 , 1918, which presented 14 proposals for the establishment of peace and a new world order after the end of the conflicts of the First World War. Available in English at: <http://avalon.law.yale.edu/20th_century/wilson14.asp>. Accessed on: 10 Jun 2018.

${ }^{9}$ Pact of the League of Nations is the charter of the League of Nations. Availabe in english at: <http://avalon.law.yale.edu/20th_century/leagcov.asp>. Accessed on: 10 Jun 2018.
} 
of collective security present in the League of Nations charter, Roger Mac Ginty (2006) points out that the peace within the States was present at the Wilsonian thought, although this was not the main focus of his thinking. Thus in Wilson's thought all people of all nationalities should have the right to live freely and equitably to their peers in any territory on the globe. The US president, therefore, on the limit, believed that the world should become safe for the advancement of democracy (p. 39).

In this way, it is possible to affirm that the Wilsonian thought has a great focus in the central element of the liberalism, which is the freedom of the individuals. In addition, Wilson's model resurrected the idea of the need for republican democracy to promote peace. Both principles defended by President Woodrow Wilson are present in Immanuel Kant's definitive articles for perpetual peace. The influence of the Kantian thought in the elaboration of what is considered the first model of the liberal peace of the modern era is thus observed.

It is worth noting that in addition to democracy in the international system and the guarantee of individual freedoms within states, Wilson's model of peace also contained the need for free trade to ensure peace between states. The idea was that the non-existence of economic barriers and the existence of equality in the conditions of trade among the nations of the globe would also help to ensure the maintenance of peace between states (Mac Ginty, 2006, p. 39).

Thus, it is possible to infer that the liberal peace model defended after the First World War already had in its formulation two central elements: Liberalism (political and economic) and; democracy. Despite the differences between the liberal peace models presented throughout the twentieth century, these two central elements figure in all models. Thus, the classification of the peace model advocated by Woodrow Wilson in 1918 as the first model of the liberal peace of the modern era is justified.

The political liberalism is understood here as the idea that the individual is elevated to the status of citizen with assured rights and that these rights are prior and more important than the notion of sovereignty and the state itself. In the modern era this thinking is reflected in the notion and dissemination of human rights. These rights are commonly associated with the idea of freedom of expression. In addition, it is diffused the idea that these freedoms are better guaranteed in political environments that are capable of guaranteeing peace and human well-being. A 
central point of the liberal political thought is the question of state interference in individual freedoms. In this sense, there must be a negotiation between the individuals and the State so that one knows in which questions there will be State interference. Another relevant point to note in liberal political thought is the optimistic thinking in opposition to the realistic principles that anarchy and warfare are part of human nature (Mac Ginty, 2006, p. 46).

Economic liberalism expresses itself mainly through the notion of free market. It is worth mentioning that the association between economic freedom and political and individual freedom is not new, despite having gained more visibility and importance after the Cold War. The absence of state regulation in the economy is understood by this theoretical current as a central component of liberalism and is seen as beneficial for the production of social and public goods and as a means to achieve political and social goals of liberal thought. Moreover, free market is understood as a means of emancipation of the individual, since the absence of state regulation will facilitate individuals to make voluntary exchanges with each other and to generate an environment of peace (ibid, p. 46-47).

However, it is important to note that although there is a correlation between free-market and the absence of conflicts between states that adopt it, adopting free market measures does not guarantee that the state will become internally and externally peaceful. This is observed, for example, in East Asian and Arabian Gulf countries which, that despite not being state-controlled economies, have little individual freedom and a high incidence of intrastate violence (ibid, p. 47-48). Thus, it is also possible to realize that political and economic liberalism are not always adopted together in domestic environments and that promoting the association between free-market and peace in a simplistic and instrumental way is methodologically and politically dangerous.

Democracy is presented as the second central element of the liberal peace. However, the version of democracy that is present in liberal peace theory is the version of Western democracy, based on the republican political system, and in many cases, the promotion of this specific understanding of democracy in post-civil society contexts does not necessarily manages peace. However, elections can bring a number of benefits to societies in transition. It is through the elections that one has the legitimation of the processes of democratization, resolution of disputes and approval of Constitutions, for example. It is important to understand that although 
they are important, elections are not the only element of a democracy. Moreover, holding an election doesn't make a democratic state instantaneously. In order to have a democracy, it is necessary the incorporation into society of democratic norms and values through a larger and more complex process than the pure and simple realization of an electoral process (ibid, p. 49-50).

In spite of the innovations brought by the League of Nations, the organization was not able to prevent the occurrence of a new global conflict 21 years after its creation. Among the reasons for the failure of the League of Nations it is possible to be highlighted the lack of legitimacy that the organization had between statesmen and rulers, the absence of the United States, and its own institutional design, considered plastered (Herz; Hoffman, 2004, p. 86-88; Mac Ginty, 2006, p. 39).

After the end of World War II, a new world order was established with the creation not only of the United Nations but also with the creation of international financial institutions and the polarization of the world between the two war-winning superpowers, United States and Soviet Union, which would dictate the dynamics of the Cold War. The Charter of the United Nations ${ }^{10}$, which brought a series of innovations in relation to the Pact of the League of Nations, was strongly influenced by the Atlantic Charter of $1941^{11}$, intensely permeated by political and economic liberalism (Mac Ginty, 2006, p. 40). The influence of liberalism on the Charter of the United Nations can be seen in its preamble:

"WE THE PEOPLES OF THE UNITED NATIONS DETERMINED to save succeeding generations from the scourge of war, which twice in our life time has brought untold sorrow to mankind, and to reaffirm faith in fundamental human rights, in the dignity and worth of the human person, in the equal rights of men and women and of nations large and small, and to establish conditions under which justice and respect for the obligations arising from treaties and other sources of international law can be maintained, and to promote social progress and better standards of life in larger freedom.

AND FOR THESE ENDS to practice tolerance and live together in peace with one another as good neighbors, and to unite our strength to maintain international peace and security,

${ }^{10}$ Available in English at: <https://treaties.un.org/doc/publication/ctc/uncharter.pdf >. Acessed on: 10 Jun 2018.

${ }^{11}$ The Atlantic Charter was a document signed by the representatives of the United States of America and the United Kingdom of Great Britain and Northern Ireland who signed cooperation between the two countries during the conflicts of the Second World War, even before the US officially entered the conflict. Available in English at: <http://avalon.law.yale.edu/wwii/atlantic.asp>. Accessed on: 10 Jun 2018. 
and to ensure, by the acceptance of principles and the institution of methods, that armed force shall not be used, save in the common interest, and to employ international machinery for the promotion of the economic and social advancement of all peoples." (United Nations, 1945, p. 3-4).

The major feature of the liberal peace model adopted during the Cold War era was the selectivity with which the United States of America shared democracy and liberalism. It was not uncommon for the two core values of Peace Liberal to be relativized to the detriment of the interests of the Western superpower. In this way, several coups d'état, dictatorial regimes and repressive measures to the population, including the North American one in the case of macarthism ${ }^{12}$, were supported by the North American governments on account of the logic of the Cold War (Mac Ginty, 2006, p. 40).

In this way, the liberal peace model presented during the Cold War brought the creation of the UN as a great innovation, with an institutional design more efficient and sophisticated than the one adopted by the League of Nations. However, the Cold War made the liberal peace model marked by a great contradiction: the suppression of freedom (political and economic) by the Western superpower in several episodes.

Thus, it makes possible to say that the model of liberal peace presented in the period of the Cold War did not necessarily have conceptual differences in relation to the model presenting in the period that followed the First World War, but operational differences. Both models had as their central objective the guarantee of systemic peace and peace between states. This issue begins to change with the end of the Cold War and, consequently, the emergence of a new model of liberal peace.

While previous models had a major focus on establishing and maintaining peace in the International System and between states, the current model has a strong focus on establishing peace, democracy, and liberalism within states (Mac Ginty, 2006, p. 37). This is mainly due to the end of the Cold War, resulting in an end of the tensions between the two superpowers, and due to the absence of tensions and

\footnotetext{
${ }^{12}$ Macarthism was a set of anticommunist measures adopted by the US government, under the command of Senator Joseph McCarthy, during the 1950s. Among the measures it is possible to highlight: The establishment of the Anti-American Activities Committee and; parallel investigations produced by the FBI. Many of the measures adopted by macarthism were not legally supported and many accusations were not formalized, being based mainly on denunciations of the population itself.
} 
conflicts between states that cause a significant impact on the international system since then.

The focus of the liberal peace model currently diffused and accepted in internal affairs of States can be verified in one of the most important documents for the consolidation of the model itself: An Agenda For Peace ${ }^{13}$. Thus, the need to establish democracy at all levels can be observed in:

"Democracy within nations requires respect for human rights and fundamental freedoms, as set forth in the Charter. It requires as well a deeper understanding and respect for the rights of minorities and respect for the needs of the more vulnerable groups of society, especially women and children. This is not only a political matter. The social stability needed for productive growth is nurtured by conditions in which people can readily express their will. For this, strong domestic institutions of participation are essential. Promoting such institutions means promoting the empowerment of the unorganized, the poor, the marginalized. (...) Democracy at all levels is essential to attain peace for a new era of prosperity and justice" (Boutros-Ghali, 1992).

In addition to stating the need to establish democracy at the interstate and intrastate level, the Agenda for Peace also coined the term peacemaking in the same report. This term came to be understood as "action to bring hostile parties to agreement, essentially through such peaceful means as those foreseen in Chapter VI of the Charter of the United Nations" (Boutros-Ghali, 1992). Two other essential differences between the model of liberal peace currently adopted and the previous models go right by the term peacemaking.

First, the current model of liberal peace, despite the criticism from various actors of the international system, is a model that has peacemaking practices that are generally not contested. This lack of contestation did not occur in previous models of the twentieth century. Secondly, the current model of liberal peace was able to promote the creation of standards of action for acting in situations of conflict. In addition, a truly functional practical, political and intellectual structure has been created in order to promote a model of peacemaking strictly aligned with the ideas of democracy and political and economic liberalism. The fact that politicians, academics, and even the public opinion take the discourse that it is

\footnotetext{
${ }^{13}$ An Agenda for Peace was a report produced by Boutros Boutros-Ghali, then Secretary-General of the United Nations, in 1992 for the Security Council and is one of the most important documents for studies and practices of peace operations. Available in English at: <http://www.un-documents.net/a47-277.htm>. Accessed on: 10 Jun 2018.
} 
necessary to "bring" democratic and liberal institutions to societies considered as undemocratic strengthens the establishment of such practices (Mac Ginty, 2006, p. 37; Paris, 2004, p. 44).

However, a question must be answered: Which factors enabled the emergence of this new model of liberal peace after the end of the Cold War? Shahrbanou Tadjbakhsh (2011) offers two possible explanations for this question. One of the explanations argues that after the Cold War there is the emergence of a "liberal moment" that was caused by the collapse of socialism, the model of social organization that opposed the liberal model, and by the emergence of civil wars around the globe. The second explanation argues that, especially after September 11 , liberalism became instrumental as a mechanism for promoting security between and within states. This fact occurs due to the diffusion of a discourse that promoted the association of development and security to liberal states and the association of insecurity, chaos and threat to the system and states that did not adopt political and economic liberalism (p. 20-21).

According to Winston's (2017) theory, which was presented and discussed in the previous chapter, about norm clusters the liberal peace itself can be framed as one. The liberal peace is framed as a norm cluster that has multiple problems, behaviors and values. As it was shown previously in this session, democracy, freemarket, individual rights and individual and collective security are core values to the liberal peace. Those values have multiple problems and behaviors associated with them. They will be introduced and discussed in the following sessions. In the chapter's conclusion the table with all the values, behaviors and problems presented and discussed within this norm cluster will be presented.

\subsection{THE LIBERAL STATEBUILDING}

As previously stated, liberal peace has a series of measures through which it manifests itself in the international system. One of these measures is the process of statebuilding. According to David Chandler (2006), the term statebuilding should be understood as a set and the development of international practices aimed at resolving cases of state collapse and helping states facing difficulties (p. 26). Verena Fritz and Aline Menocal (2007) go further and define that the term statebuilding:

"[r]efers to the set of actions undertaken by national and/or international actors to establish, reform and strengthen 
state institutions where these have seriously been eroded or are missing. Key goals of state-building include provision of security, establishment of the rule of law, effective delivery of basic goods and services through functional formal state institutions, and generation of political legitimacy for the (new) set of state institutions being built" (p. 13).

Having the definition of the term in mind, it is important to understand the context in which the processes of construction and state reconstruction begin to gain space on the international agenda. The agenda for statebuilding began to develop precisely in the aftermath of the end of the Cold War and became more important after the terrorist attacks of 11 September 2001, mainly because of the perception of Western powers that so-called "fragile states"14 have become a credible threat to the promotion and maintenance of international security. That is, it became extremely difficult to decouple statebuilding practices from the term and discourse on "fragile states" (Duffield, 2007, p. 160; Paris; Sisk, 2009, p. 11-12; Robinson, 2007, p. 2).

Commonly, the Organization for Economic Cooperation and Development (2008) definition of state fragility is used, considering that "states are fragile when state structures lack the political will and/or ability to perform the basic functions necessary for poverty reduction, development and guarantee of the security and human rights of their populations" (p.16). It is worth noting that there are initiatives that, through quantitative and qualitative methods, have developed ranks of state fragility. The most well-known ranking used in studies is that produced annually by the non-governmental organization (NGO) Fund For Peace.

According to Mark Duffield (2007), the concept of state fragility is used by the West to demonstrate "goodwill" and engagement in promoting development in these regions and, consequently, international security, since the reconstruction and development of these states is understood as measure of counterinsurgency. Moreover, this view still promotes the association between poverty and insecurity at both local and international levels (p. 160). There is, therefore, increasingly a closer relationship between security and development, both in theory and in

${ }^{14}$ There is a great debate in International Relations, especially involving authors of Critical Theory, Post Colonial Theory, and Post-Structuralist Theory about the validity and interests behind the concept of Fragile States. However, the present work does not focus on this debate. The use of the concept here is done exclusively with the intention to present the discussion about statebuilding, not implying, therefore, in the agreement of the author with the term. For a more critical reading on the subject it is recommended to read: KAPLAN, Seth. Identifying Truly Fragile States. The Washington Quarterly, v. 37, n. 1, 2014, p. 49 - 63. 
practice, which has led to the creation of the so-called "security-development nexus" (Grimm; Lemay-Hébert; Nay, 2014, p. 199).

Oliver Richmond (2014) considers that statebuilding is the representation of an attempt to make the whole world subject to a specific political order (p. 63). This fact occurs because during the processes of construction and state reconstruction some specific measures are used aiming the creation of a specific type of governmental and state structure based precisely on the norms and liberal ideas of democracy and market economy. In addition, there is the adoption of the model of the national state centered on the Western conception of the nation (Kostic; Krampe; Swain, 2014, p. 43).

Patrick Tom (2017) argues that there are two different approaches to the state: (1) The institutional and; (2) the legitimacy approach. The first approach is largely influenced by the Weberian idea of statehood, viewing a state as a political entity that has monopoly over the legitimate use of violence. In this sense, it focuses on building effective state institutions in post-conflict environments as remedy for the "weirdness", "abnormalities" and/or "weakness" found in the "fragile states". This approach also tends to ignore customary institutions, since it places emphasis on building the capacity of state institutions. State's capacity to institutionalize its diverse organizations is also considered as an important element of the state, according to this perspective. Doing so, it is expected that the durability of the state and it is institutions last so long that even the death of a national leader would not result in the collapse of the state, the whole process of statebuilding and its current progress (p. 56-57).

The second approach considers issues of legitimacy as of primary importance when building states. Doing so, it finds the focus of the institutional approach on institutions insufficient and also argues for the need to focus on social and political cohesion and the legitimacy that central authorities can generate. Thus, this approach is also related to issues related to social an political cohesion and how external actors shape conditions under how social integration is enhanced in postconflict environments. So, it can be said that this approach is committed with the nation-building idea. However, it must be noted that external actors involved in "building nations" is extremely contradictory with the theoretical understandings and empirical experiences of the nature of a nations and its formation. Therefore, having this in mind, emphasizing the state legitimacy only makes sense when the 
state needs to be acceptable to its citizens for them to be able to rally behind its authority, a fact that supposedly enhances its stability and order (ibid, p. 57).

Fairlie Chappuis and Heiner Hänggi (2013) argue that especially after the 1990s security sector reform (SSR) agenda was incorporated in the statebuilding processes around the globe. This fact occurred mainly due to three factors: (1) the recognition among the donor community that security should be treated as a developmental issue; (2) the importance of SSR as an element of democratization and; (3) the growing involvement of international stabilization operations (which will be presented and discussed later) in post-conflict security sector construction and reconstruction (p. 168).

The authors also point that from a statebuilding perspective, SSR is mainly the expression in policy of the specific concept of governance and state authority upon which liberal peacebuilding is based. The idea of good governance of the security sector is a key-concept present in this framework. So, a civilian and democratic control on who uses force, when, why, and how is also desirable in this model. Having this in mind it is argued that:

"The point of SSR as a policy agenda is not just to ensure that the state alone has the ability to use violence; that is, to eliminate all violent challenges to the existing political order from non-state actors. Indeed every dictatorship monopolizes violence successfully. The point is also not to make the security forces more effective in how they use violence: every repressive state is backed by security forces that are very effective in the use of force. Instead the central importance of SSR is in changing the way the state uses its monopoly on violence by making it legitimate and accountable according to the precepts of good governance that are part of the liberal statebuilding paradigm. Programs that do not aim to establish good governance of the security sector - for example focusing exclusively on the effectiveness of the security forces without regard for how they are controlled and to what end - cannot be rightly described as SSR, even though they may entail changes to the security sector that may be entitled 'reform."' (Chappuis; Hänggi, 2013, p. 170171).

The fact that international peacebuilders emphasize the creation of liberal market democracies in states emerging from violent conflict has led a significant number of scholars to achieve the consensus that in the post-Cold War the international peacebuilding activities reflect a liberal agenda, highly influenced by the liberal peace theory. Therefore, the liberal statebuilding, focused in building a liberal state, a free market economy, the promotion of SSR, the guarantee of individual rights, the rule of law and the democracy is the mainstream practice in 
the international scenario (Tom, 2017, p. 59). However, it must be noted that this statebuilding framework and actions are highly oriented by a western-liberal view on politics, individual and security affairs. These facts make the liberal statebuilding a target of criticisms by scholars and practitioners.

One of the biggest criticisms is precisely the lack of participation and importance of local populations in the process (local ownership). Lack of engagement and empowerment of the local population consequently lead to neglect of other forms of life, non-recognition of other forms of social, economic and institutional organization. It is therefore not uncommon for statebuilding processes to be accused of being part of a neocolonial project whose primary purpose is to replicate the Anglo-American version of the state and western values as if they were universal and necessarily positive (Richmond, 2014, p. 82).

Another major challenge historically present in the processes of statebuilding and state reconstruction is the creation of a state structure that can, in the long run, maintain stability and legitimacy. This concern occurs because, generally speaking, there is a great concentration of efforts for the State to have the legal monopoly of the means of coercion and the use of force in Weberian terms. In addition to this, there is a very large focus on the electoral issue, with much of the effort being shifted towards elections and plebiscites in order to decide on the political organization to be adopted and the representatives to be elected. In this way, there is the creation of a state structure that is limited both in its functions and by a strong society. Thus, there is a very great focus on the construction of the state structure and little focus on the construction of a real social structure that allows for the stability and legitimacy of the state structure itself (Barnett, 2006, p. 93).

In addition to these well-known and mainstream questions, Roland Kostic, Florian Krampe and Ashok Swain (2012) present a critique of identity and ethnicity. The authors argue that statebuilding processes end up reproducing liberal social theory about the formation of States and nations in which modernization would lead to greater mobilization and assimilation of local communities. In this theory, the assimilation of different ethnic groups is merely a matter of social engineering. This approach is strongly influenced by the experience of European and American state formation, thus not reflecting the experience of many societies in which the practice of liberal statebuilding (p. 44). 
As a result of this reproduction of the liberal social theory, the existence and possibility of the existence of a set of ethnic-national communities that are organized in national movements to achieve, themselves, all the attributes and the recognition that the nations considered as developed are ignored. Thus, liberal statebuilding does not take into account the effects of its impositions on ethnicnational identities in local societies and also does not take into account that there is a cause and effect relationship between insecurity and stress in the social and social policies and economic policies adopted by it (ibid, p. 44-45).

Thus, it is important to note that these criticisms arise specially because of the failure of liberal statebuilding to deal with local problems in the 1990s and 2000s and to prevent further conflicts from occurring after the occurrence of statebuilding measures. Among the cases of failure of liberal statebuilding, it is possible to mention: Cambodia; Bosnia Herzegovina; Kosovo and; East Timor. However, it is important to note that despite the criticisms and flaws in the models of liberal statebuilding, these models continue to be disseminated in the practices adopted by the United Nations and other relevant international players in these processes.

As presented and discussed above it can be stated that political instability, lack of democracy, civilian conflicts and state fragility are considered as problems in the liberal peace norm cluster, following the theory from Carla Winston (2017). In this same context, the promotion of free elections, political reform, security sector reforms and the adoption of measures of political and economical liberalization are seen as behaviors of this norm cluster.

\subsection{STABILIZATION}

Since the 1990s, the international community has been exploring mechanisms to combat insecurity and prevent violence. In this way, a number of measures were adopted by developed states in the regions and states considered as "fragile", as like as already discussed previously in this chapter. As such, a series of peacekeeping operations (PKOs) were launched and adapted to the needs of the terrain and also to the interests of the decision makers. Thus, it was possible to observe the emergence of PKOs' mandates increasingly comprehensive in terms of civilian and governmental tasks, as well as deeper in the use of force by the troops. 
In this way, it can be said that PKOs have become more and more multidimensional. In this way, the practice of statebuilding, which gained strength in the 1990s and 2000 , was broadened as shown in the previous session. In this context, the so-called stabilization practices can be considered only as the last formulation of developed states to respond to insecurity and poverty in the periphery of the international system (Muggah, 2013, p.2).

Nevertheless, the definition of stabilization itself has been considered a challenge for academics and also for state and international agents of the international system because of the lack of analytical precision of the term. Thus, it is possible to say that there are two prospects for stabilization operations: (1) the first one led by the United States in its interventions in Iraq and Afghanistan and; (2) the second led by developing states in their actions in peripheral regions. However, in all of these perspectives the main objectives are shared, namely: The creation of a safe environment, the establishment of the rule of law, achieving stable governance and enabling economic growth and enabling conditions for the promotion of social welfare (ibid, p. 3-4).

Sultan Barakat, Séan Deely and Steven Zyck (2013) argue that the stabilization missions are operations that involve not only offensive and defensive actions in the field but also diplomatic and developmental efforts in order to promote peace and security in countries affected by conflicts and instability. To do so, they aim to promote a peaceful political settlement in which a legitimate indigenous government can serve its people. Therefore, stabilization operations are understood as actions that intend to establish peace in countries affected by conflict and instability and to promote a peaceful political settlement to produce a legitimate indigenous government, which can serve its population (p. 17-18).

The authors also argue that stabilization operations are also inspired in a kind of theory of change composed of four spatial and temporal moments. In the first moment, actions are done in order to have the territorial control, provide the basic human needs and well-being for the local population and build a political legitimacy vis-à-vis the population. In the second moment it is expected that the population support for the state and/or its international backers actions in the field. In the third moment the insurgents lose the active and passive support of the population and the actors involved in the stabilizations processes gain acquiescence and/or support of the population. In the final stage of the stabilization there is a 
military victor by the stabilization actors and, consequently, the insurgents flee and occurs a stalemate that inherently leads to a political settlement (ibid, p. 18).

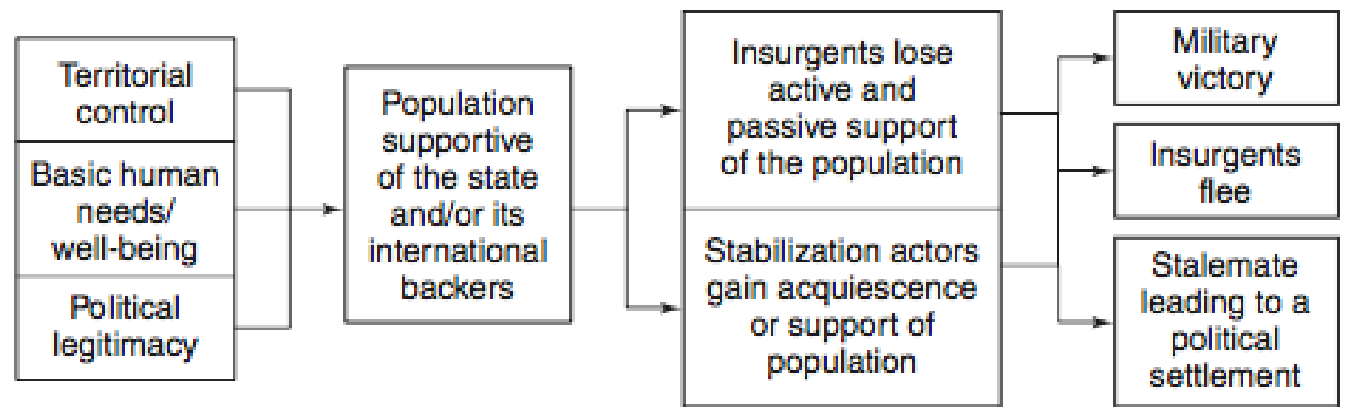

Figure 1 - Stabilization Theory of Change

(Source: Barakat; Deely; Zyck, 2013, p. 18)

It is worth noting that in the UN context, stabilization operations, since MINUSTAH's creation, have been associated with a "robust" mandate and a very permissive use of military force. In many cases, especially in the Democratic Republic of Congo, the troops under UN command are authorized to use force offensively in order to accomplish the mandate's objectives. In the so-called Cruz Report (2017), which looks at concrete ways to reduce fatalities in UN peacekeeping and reopened questions of whether UN peacekeepers are ready to act decisively in the face of direct attacks, it is argued that "to deter and repel attacks and to defeat attackers, the United Nations needs to be strong and not fear to use force when necessary" (p. II), expressing the nature of the stabilization missions 
under the UN spectrum, which in general terms flexibilize the "Holy Trinity" PKOs, as can be seen in the following stretch:

"The United Nations should provide an updated interpretation of the basic principles for peacekeeping. Troops should not see the principles as restrictions on the initiative and the use of force. The principles should clarify that in high-risk areas featuring high-intensity conflicts (ambushes, for instance), troops should use overwhelming force and be proactive and preemptive. In battles and in fights, the United Nations needs to win, or troops, police and civilian personnel will die" (ibid, p. II).

Another point that must be noted is that although the United Nations has been using increasingly the term "stabilization" in its own missions and documents, the Organization itself doesn't have a single definition for the term.

It can therefore be said that there is a minimal consensus on the objectives of the stabilization processes carried out by both the major powers and the developing states. That is, there is a set of actions that can be characterized as stabilization actions. However, what is, in fact, stabilization and what are its components remains a challenge. In an attempt to position stabilization within the discussions on International Security, Robert Muggah (2013) elaborated a framework in which stabilization has elements of a number of other concepts, such as: peacebuilding; statebuilding; counterterrorism; counter-insurgency and; development. The table can be viewed below:

\footnotetext{
${ }^{15}$ The "Holy Trinity" of United Nations peacekeeping operations are three key-principles that guide the troops actions in the field: (1) The consent of the host nation(s); (2) impartiality (equal treatment without discrimination) between the conflict factions and; (3) The non-use of force by United Nations troops.
} 


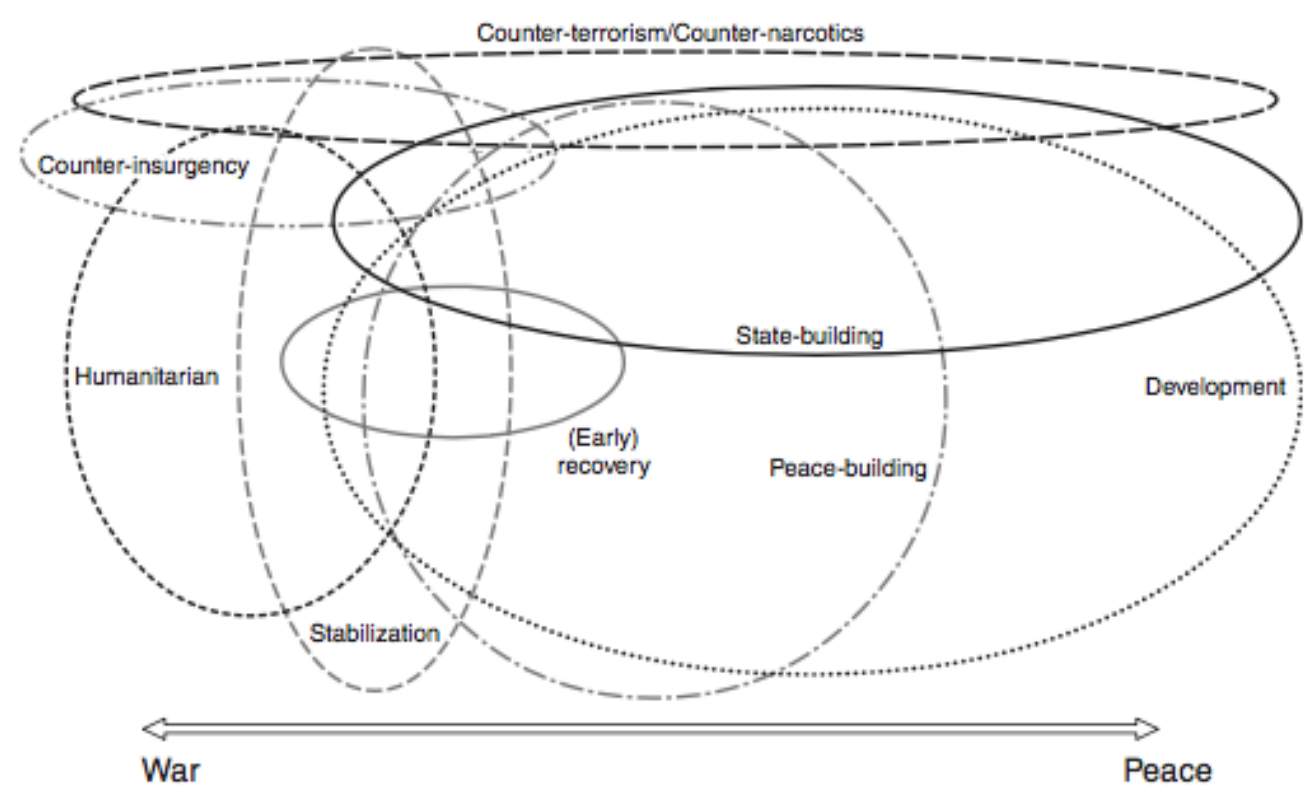

Figure 2 - Stabilization Framework

(Source: Muggah, 2013, p. 5)

As shown above, stabilization has various components and is composed of numerous types of concepts and practices. Precisely because of this it must be noted that although stabilization and liberal statebuilding share the vision that the socalled "fragile states" are a threat to the international system and peace, their actions differ. As presented above, stabilization operations do not aim to build state structures and provide public goods as statebuilding actions do. As a practice, stabilization aims only "to establish peace in countries affected by conflict and instability and to promote a peaceful political settlement to produce a legitimate indigenous government, which can serve its population" without high level of preoccupations concerning the way the state itself will be organized, preoccupation present in the liberal statebuilding processes.

It should be noted that stabilization practices are not seen as positive by Roger Mac Ginty (2012) who argues that, in fact, they represent a fetish of Western states and international organizations of control and order without weighing the consequences for the peace itself and also for local autonomy and freedom. In this way, there is no possibility of emancipation and, in the limit, it reduces the horizons for reach of the so-called sustainable peace, both theoretically and practically. Despite this, the author emphasizes that there is no criticism of stability and its benefits, but rather of stabilization processes (p.25). 
The discussion on stabilization realized above allows affirming that stabilization operations are a behavior of the liberal peace norm cluster. This fact occurs since this kind of operation intends to combat the problems that compose this norm cluster and its attitudes are composed by means that also compose others behaviors that are framed within the norm cluster.

It should be borne in mind that the concept of stabilization is still a disputed concept and its reading as part of the liberal peace norm cluster is not the only possible reading. There are several studies within other theoretical and epistemological perspectives within the IR discipline that also deal with this phenomenon, but focusing on other issues. In this sense, the proposal to frame stabilization as a behavior within the norm cluster of liberal peace does not exclude its possibility of divergent and / or complementary readings by other theoretical lenses.

\subsection{CONCLUSION}

The present chapter intended to discuss the liberal peace trough the norm literature on international relations, specifically the Carla Winston (2017) work on norm clusters. It was argued that the liberal peace could be framed as a norm cluster composed of multiple problems, values and behaviors. To do so it was firstly presented a brief discussion on the perpetual peace and its importance to the modern concept of liberal peace and the historical existence of three models of liberal peace in the international politics since the 1918 and its characteristics, similarities and divergences. Then, the liberal statebuilding was discussed presenting not only the concept but also its critics by academics and practitioners. Finally, the stabilization operations were brought into this discussion and it was observed that this concept lack of a formal definition not only in academia but also in the United Nations and it was observed that there is a trend that points to the use of the term in PKOs that are considered "robust" and flexibilize the so-called holy trinity.

It was observed that liberal peace cannot be framed as a single norm since this theory orients and influences a huge and significant number of actions in the international system and deals with a significant number of questions of the international relations. The liberal statebuilding and all its components are only one way trough which the liberal peace express its influence. It is important to note that 
although the stabilization operations are not commonly associated with the liberal peace agenda (they are commonly associated with a post-liberal peace agenda), it was observed that statebuilding and this kind of operations share multiples understandings on which points should be considered as problems of the international system and how these problems should be solved.

Having these discussions and points in mind, throughout the chapter, it was argued that the liberal peace norm cluster is composed essentially of four main problems (political instability; lack of democracy; civilian conflicts and; fragile states), five main values (democracy; free market; the guarantee of individual rights; collective security and; individual security) and four main behaviors (political liberalization; security sector reforms; economical liberalization and; stabilization). The synthesis of the liberal peace norm cluster discussed throughout this entire chapter is shown in the table 1, placed below.

\begin{tabular}{|ccc|}
\hline Problems & Values & Behaviors \\
& & Political \\
Political Instability & Democracy & Liberalization \\
Lack of Democracy & Free Market & Security Sector \\
Civilian Conflicts & Individual Rights & Reforms \\
State Fragility & Individual Security & Economical \\
& Collective Security & Liberalization \\
& & Stabilization \\
\hline
\end{tabular}

Table 1 - liberal peace Norm Cluster

Finally, it should be emphasized that the components of the cluster presented above can undergo changes and new incorporations depending on international practices and norms. In addition, the problems, values and behaviors that integrate it are not exclusive to this clusters, but their integral parts. This means that these components can be part of more than one norm cluster, even those which may be considered as "competitors" of the liberal peace norm cluster. 


\section{BRAZILIAN ENGAGEMENT AND CONTESTATION ON PEACEBUILDING}

The previous chapter discussed the origins and the formation of the liberal peace theory and it was argued that the liberal peace could be classified itself as a norm cluster. In this sense, the liberal peace theory was presented from a historical perspective and the practical means through which this cluster manifests itself were presented. Thus, the literature on statebuilding, security sector reforms and stabilization were presented as well as their main criticisms.

The present chapter aims to discuss how Brazil engages in discussions and practices of peacebuilding. It is argued that Brazil has developed a set of concepts and practices composing a "Brazilian way of peacebuilding", influenced by some important concepts and principles from Brazilian foreign policy, in opposition to the mainstream set of practices widely used by developed countries such as NATO members.

To do so, this chapter is structured as follows. First, I argue that the global liberal order that emerged after the end of the Cold War faces a process of contestation, especially by the so-called emerging powers. I then present the extent of Brazilian engagement on international security during the last 20 years, after the redemocratization of the country. After that comes a discussion about the importance that Brazil gives to the principle of non-intervention in its foreign policy since its independence, as well as the recent incorporation of another principle (nonindifference) into the country's foreign policy in contrast/complementarity of the first one. Ending the argument, a brief presentation about the historical Brazilian contribution to the United Nations peacekeeping missions will be made, as well as "the Brazilian way of peacebuilding", which will be read through the lenses of the work done by Nicole Deitelhoff and Lisbeth Zimmermann (2013) and Antje Wiener $(2004 ; 2007 a ; 2007 b ; 2014)$ on norm contestation. Finally, the conclusions obtained during the development of the present chapter are presented. 


\subsection{BRAZILIAN NORMATIVE INITIATIVES IN THE GLOBAL LIBERAL ORDER}

The global liberal order that emerged after the end of the Cold War, and consolidated under the US influence, is constantly contested. In this sense, many countries, specially rising powers, seeks to gain space in important discussions about the international politics and the global order itself. For the last 20 years Brazil has been challenging the global order seeking to change the structure of power in the world today.

The increasing Brazilian interest in playing a relevant and growing role in the international politics coincided with the period of consolidation of the country's democracy and economy, after a long period of a dictatorial regime and a long financial crisis during the 1980s and early 1990s. During Fernando Henrique Cardoso (FHC)'s presidency (1995-2002), Brazil started to cautiously look abroad to play the role of a pro-democracy actor in Latin America, emphasizing the creation of relations with a host of governments in the region in ways that neither trespassed on Latin America partners' sensitivities about the country itself, nor directly contested the US regional dominance and influence. In this way, Brazil has played an important role in negotiating conflicts between its neighbors in the past 20 years (Stuenkel; Taylor, 2015, p. 2).

During the FHC presidency, Brazil started the construction of an engagement in regional questions, but it was only during Luis Inácio Lula da Silva's presidency (2003-2010) that the country engaged in the strategic construction of a more robust international role, going beyond the South and Latin America regional initiatives, and simultaneously gave great pride of place to global South-South relations. In the regional sphere, Brazil and other nations created the Union of South American Nations (UNASUR), with the reduce the role and influence of the United States in the regional affairs and regional negotiations with other global actors, without seeking to abolish the Organization of American States (OAS), which is commonly perceived as focused on Washington's hemispheric security concerns. It is also important to note that Brazil began to engage with questions and area outside of the country's regional sphere of influence during the Lula administration. The most notable attempt was the joint initiative with Turkey in 2010 to negotiate a nuclear agreement with Iran (ibid, p. 3-4). 
In this way, the Lula presidency represented an important step in the Brazilian ambition to become a global player and to play an increasingly role in the international system. Oliver Stuenkel and Matthew Taylor (2015) also point that during Dilma Rousseff administration (2011-2017) one of the biggest Brazilian attempts to play an important role in questions concerning international security was made. In 2011 Brazil was deeply engaged in the global debate about humanitarian intervention. After the approval of the United Nations Security Council Resolution $1973^{16}$ on March $17^{\text {th }} 2011$, the use of the concept of Responsibility to Protect (R2P) in the resolution and the interpretation that NATO gave to the concept during the Libyan crisis Brazil has launched the concept of Responsibility while Protecting ( $\mathrm{RwP})$ in contrast to the $\mathrm{R} 2 \mathrm{P}(\mathrm{p} .4)$.

The Brazilian concept gained some popularity, especially in the Global South countries, and was commonly understood as a constructive proposal. Several commentators and diplomats from many countries argue that the RwP proposal was attempt by Brazil to assume international norm leadership, engaging in a debate that previously was not seen as a priority (Brockmeier; Stuenkel; Tourinho, 2015, p. 9). Although, it is important to note that this Brazilian initiative achieved controversial results and nowadays the RwP concept is almost forgotten by the Brazilian diplomacy and is not mentioned in the discussions on humanitarian intervention as it was in the years 2011 and 2012.

Through the RwP initiative, Brazilian diplomacy questioned the utility of the use of force as a solution the root causes of local conflicts. The Brazilian attitude has also demonstrated that in the debates about sovereignty and the importance of this principle in international security it is located a key point in the movements of contestation of the distribution of global power, traditionally dominated by Western states and the so-called Global North. So, it can be said that the debates on interventions became a key locus for emerging powers constructively to give normative content to their challenges to the established order (Kenkel; Martins, 2016, p. 22-23).

Felippe De Rosa and Kai Michael Kenkel (2015) also point out that the RwP initiative demonstrated an important point of the Brazilian diplomatic thinking regarding Brazilian action in security debates, mainly in the United Nations. Brazil

\footnotetext{
${ }^{16}$ United Nations Security Council Resolution 1973 from $11^{\text {th }}$ March 2011. Available in English at: 〈https://undocs.org/S/RES/1973(2011)>. Accessed on: 31 Jul 2018.
} 
has a clear preference to act as a norm maker rather than acting as a norm taker. The RwP case, in particular, demonstrates that the Brazilian attitude represented an attempt by Brazil to show itself as a voice and an active agent and representative of the so-called Global South (p. 348-349).

Therefore, it becomes clear that the Brazilian diplomacy has been seeking, through individual or group actions, to expand its presence in international security debates. Within this agenda, one of the most relevant points is the expansion of Brazilian responsibilities in this debate and in the practice of international security as such. In order to do so, since the end of the 1990s there is a significant expansion of Brazilian actions in multilateral interventions, in situations of humanitarian crises and natural disasters, and especially in post-conflict reconstruction scenarios (Hirst, 2015, p. 43).

In sum it can be said that Brazil during the last 20 years has constantly reinforced it historical aim to become a global player and play an important role in the international system. In this context, the country increasingly engaged not only in debates about international security but also in practices and initiatives of it. Therefore, the next pages are intended to present the Brazilian vision about the liberal peace practices presented in the past chapter, particularly focusing on the Brazilian approach to peacekeeping, also debating the question about the principle of non-intervention, and statebuilding.

\subsubsection{FROM NON-INTERVENTION TO NON-INDIFFERENCE}

Historically, the Brazilian state has adopted, with rare exceptions (Paraguayan War and World War II), the principle of non-intervention in internal affairs of the other states of the international system. The principle of nonintervention is even present and established in the Federal Constitution of 1988 in its Article 4 and its application dates back to the time when the Baron of Rio Branco held the position of Brazilian Minister of Foreign Affairs.

Marcos Tourinho (2015) stresses that since its independence Brazil has been encountering and defending the principle of non-intervention for several times in different contexts. Firstly, in the context of the Monroe Doctrine, at the Panama Conference of 1826 the Brazilian diplomacy understood the American doctrine as a measure to avoid the European intervention in the region and tried to formalize 
the doctrine jointly with other Latin America states in a treaty of security alliance. Although, the United States rejected the proposal (p. 85).

In the Second Hague Conference, in 1907, Brazil denounced that the Roosevelt Corollary, from 1904, transformed the Monroe doctrine into an US instrument of hegemony in the region. Doing so, the country was determined to push for the establishment of mechanism that could avoid intervention and provide guarantees for foreign investors to remain interested in countries like Brazil, but at the same time sought to preserve the fundamental interests for creditors (ibid, p. 86).

During the Cold War a fundamental turning point in Brazil's position regarding intervention occurred. In 1961 the Brazilian Minister of Foreign Affairs, San Tiago Dantas, stated that the Brazilian nation could not avoid from being a nation that is decidedly engaged in the preservation and application of the principle of non-intervention in the lives of the peoples. In this sense, Dantas argued that Brazil was conscious of its responsibilities towards international order and would always be loyal to the emancipation and economic development of all people. It was also stated that Brazil was an independent nation, loyal to all democratic principles not only in its own internal order, but also in the international order. However, during the military dictatorship that ruled the country for more than 20 years, Brazil de-emphasized democracy as an international value, but maintained emphasis on international cooperation, international institutions and stressed, even more, the norm of non-intervention (ibid, p. 86-87).

During this historical context, Brazil started to be more committed to the processes of decolonization around the globe, especially in the African and Asian continents, and increased its relations and ties with countries of the so-called Third World. This period and actions were crucial to determine the country's positions on non-intervention and to increasing its sympathy toward the post-colonial cause in a broader sense. After the end of the Cold War these topics gained more importance in the international system, but the Brazilian positions remained largely unchanged and were incorporated into its constitution and into the fundamental basis for its diplomats' formation (ibid, p. 87).

However, during the Lula administration, the Brazilian Ministry of Foreign Affairs started to use a term, never used before by the country: non-indifference. According to Tim Murithi (2009), this concept emerged in the African Union (AU) 
as a response to the failure of its predecessor, the Organization of African Unity (OAU), in solving the conflicts that the region faced in the 1980s, 1990s and early 2000s. Alpha Oumar Konare, former Chair of the African Union Commission, advocated in favor of moving from a culture of non-intervention to a culture of nonindifference in order to avoid the same mistakes from the past (p. 92).

In the African context the concept of non-indifference took place into a multilateral framework since the General Assembly of the AU or any member state has the legitimacy to request assistance, according to the fourth article of the AU constitution. In this sense, if an intervention is approved, the Peace and Security Council of the AU monitor it. Thereby, the African Union has an interventionist power, that gradually promotes the erosion of absolute sovereignty, allowing intervention in states that refuse to provide answers to the needs of their populations or that put their safety in risk (Alles; Ekström, 2012, p. 12).

In the Brazilian foreign policy, the concept of non-indifference gained a more hybrid character since it is not subjected to a multilateral organization, nor any national law regulates it. In the Brazilian case top officials of the Lula administration used the non-indifference concept in statements trying to focus not only to the military solutions for humanitarian crisis, but also to identify and solve the root causes of political and economical crisis and instabilities. It must be noted that the use of non-indifference in the Brazilian case represents a selective incorporation of assumptions concerning into preexisting analytical frameworks adapted to Brazilian needs. In this context, the concept is understood as diplomatic component also devoted to peace, but that enables a mediating role in humanitarian crisis, conflicts and even gentle intervention (ibid, p. 12).

Celso Amorim, former Brazilian Minister of Foreign Affairs, argued that the Brazilian foreign policy is not moved exclusively in its own interests as the pursuit of immediate gains, but it is also set in motion to carry out actions of solidarity. In this context, the principle of non-indifference is understood as the idea that although Brazil does not have the right to interfere in the sovereignty of each state to solve problems, it is necessary that Brazil should be willing to help the neighbors states when called. This aid must occur especially when there is clear evidence or the occurrence of serious political and social crises (Hermann, 2011, p. 205-206). It is important to note that the Brazilian action is, therefore, conditioned to the invitation and acceptance by the state where it will take place. 
Regarding about the motivations that led the Lula government to incorporate the principle of non-indifference not only in Brazilian diplomatic activity, both rhetorically and practically, Breno Hermann (2011) argues that:

"The rationale for non-indifference to become a vector of foreign policy lies in the explicit commitment assumed by the government of former President Lula with the improvement of the living conditions of the Brazilian population. Although foreign policy is ultimately the translation into the international sphere of a specific political program, in this case the distinctive feature is that domestic commitment has its equivalent in a broader commitment based on the value of solidarity for the benefit of neighbor countries and their populations, from a perspective that is characterized as humanist. It is precisely this perspective that allows us to understand in depth the nature of certain initiatives insofar as it relates to the human capacity to modify a socially unjust reality" (p. 206. My translation).

Maria Regina Soares de Lima (2005) points that although the concept of non-indifference may be used to legitimize interventions, in the Brazilian case it revealed the new international provisions of the country and linked this type of practice to the expressed commitment of the Lula administration to social inclusion and its policy of eliminating the problem of endemic hunger and absolute poverty. The counterpoint to the concept of non-intervention, which is fundamental in the Brazilian diplomatic tradition, could not be more illustrative of the difference that was intended to be established during Lula's presidency (p. 19).

To summarize, the concept of non-intervention is a keystone of the Brazilian diplomacy since its proclamation of independence. For nearly 300 years the understanding and use of this concept by Brazilian politicians and diplomats has varied significantly. One of the greatest innovations in Brazilian foreign policy conceptually occurred throughout the Lula administration, which incorporated the concept of non-indifference, originally used by the African Union, in a hybrid way, associating it with actions to combat poverty, hunger and social inequality giving a moral burden to foreign policy actions that were justified on the basis of it. In this context, Brazil has always been averse to interventions without the legal authorization of the receiving country or of competent multilateral organizations.

\subsubsection{THE BRAZILIAN CONTRIBUTION TO UN PEACEKEEPING AND "THE BRAZILIAN WAY OF PEACEBUILDING"}

Although Brazil started to play an important role in United Nations peacekeeping after the end of the Cold War in the 1990s, the country has been a 
troop contributor, with military, police and civilian personal, since the very first UN peacekeeping operation in 1947. The post Cold War period Brazil has started to organize its engagement in UN peacekeeping as a tool of its foreign policy. Its contribution to UN peacekeeping is perceived not only as an act of contribution to the international order, but also and mainly as an act of promotion of its regional and global interests and expansion of its role in the international system (Cezne; Hamann, 2016, p. 1).

Ramon Blanco (2017) argues that the de Brazilian engagement in UN peacekeeping is not uniform and can be divide into four main phases: (1) From 1957 to 1967; (2) from 1968 to 1988; (3) from 1989 to 2004 and; (4) from 2004 onwards. During the first phase, Brazil contributed with a small number of troops to the UN peacekeeping operations, with the exception of the United Nations Emergency Force (UNEF) during the second half of the 1950s, which was the most significant Brazilian contribution during the Cold War. The second phase of the Brazilian engagement with the UN peacekeeping is precisely characterized by the disengagement of the country with peace operations. During this phase the number of troops displaced by the country for peace operations was very small. It is important to note that during the major part of the first and second phases of the Brazilian enrolment with UN peacekeeping the country was ruled by a military dictatorship (p. 4-5).

The third and the fourth phases represent the reengagement of the country with the peace operations and an increase of the Brazilian contribution can be observed during this period. Right after the re-democratization of the country is located the third phase, which is characterized by the country's engagement with the so-called second-generations peace operations ${ }^{17}$, displacing troops to countries such as Mozambique, Angola and El Salvador. The end of the Cold War, in the international context, represented the thawing of the Security Council and the increase of resolutions approving peace operations. The fourth phase is represented by the Brazilian engagement in MINUSTAH, which placed the country as a

\footnotetext{
17 The present dissertation does not aim to discuss about the division of the United Nations peacekeeping operations into generations. The use of the term here is only for practical reasons, not implying the author's agreement with it. For more information on this discussion it is recommended to read: KENKEL, Kai Michael. Five generations of peace operations: from the "thin blue line" to "painting a country blue". Revista Brasileira de Política Internacional, v. 56, n. 1,2013 , p. $122-144$.
} 
fundamental contributor to the practice of peacekeeping not only in the regional sphere, but also in the global sphere. The fourth phase distinguishes itself from the other phases in two main respects: the number of troops displaced and operating in post-conflict scenarios; and the unprecedented degree of responsibilities undertaken in the sphere of international peacebuilding (ibid, p. 5-6).

João Paulo Alsina Júnior (2017) shows that regarding importance of the principles of non-intervention, sovereign equality of states, and peaceful settlement of disputes for the Brazilian foreign policy, the country on several times refused to participate on peacekeeping operations that were established under the Chapter VII of the United Nations Charter. The author argues that another important characteristic of Brazilian multilateral diplomacy is the constant reiteration of the link between poverty and conflict. In this context, the diplomatic rhetoric of the Brazilian Ministry of Foreign Affairs in its approach of issues is related to peacekeeping operations is pervaded by a developmentalist thesis that observes the poverty reduction as a means of minimizing the occurrence of conflicts. This rhetoric is also based on historical demands in favor of greater equity in the distribution of international wealth. Because of this, Brazil defends the execution of quick impact projects and advocates that peacekeepers should perform peacebuilding tasks from the start of peace operations (p. 7).

Adriana Abdenur and Charles Call (2017) show that when Brazil occupied a non-permanent seat at the United Nations Security Council in the years of 20042005 and 2010-2011, the country argued that the United Nations was neglecting its original focus on conflict prevention and post-conflict reconstruction in favor of heavy-handed military interventionism, whether led by NATO and its allies (p. 11). This fact shows that Brazil is not against the use of force as a measure to solve humanitarian crises, but is against its use as if was the only solution.

Regarding the so-called "failed states", a label that has always been avoided by Brazilian diplomacy, the country has always been against military and political interventions in states classified as failed. The Brazilian diplomacy criticize this terminology for reproducing stigmas and preconceived views, in which it questions the sovereignty of the countries in question and paves the way for interventionist solutions. These identities are perceived as damaging to countries whose situations of extreme poverty and lack of institutional resources are a consequence of the asymmetric structures of resource and power distribution, often caused by the states 
in which such labeling is created. These countries should be deserving of actions that express solidarity and commitment, but also consent. It was precisely in this way that the Brazilian diplomacy relativized the primacy of non-intervention by embracing the principle of non-indifference (Hirst, 2015, p. 49).

Thus, Brazil has historically demonstrated aversion to the approaches that followed the pattern of liberal peace and the United Nations in actions in humanitarian crises. One of the major points of criticism is the style and militarized approach of interventions promoted by the West, particularly by the US and NATO, and which, in the Brazilian view, represents an extremely difficult way of dealing with situations of risk. This approach is perceived as exactly the same as those adopted in situations of risk during the Cold War (Abdenur; Souza e Neto, 2014, p. $4)$.

Another point that has been very present in Brazilian diplomatic activity since the 1980s, when the country was redemocratized, is precisely the question of the promotion of the democracy. However, during these years there was an ambiguity and uncertainty regarding the application of measures to promote democracy, since the notion of sovereignty and non-intervention were strongly present in the Brazilian foreign policy, as already mentioned in the previous session. In this way, Brazil has criticized various military interventions authorized by the United Nations and carried out through other mechanisms and has also criticized the classification of the US and some European countries as defenders and promoters of democracy and human rights since those same countries are criticized for violating both principles in various current and historical moments (Abdenur; Souza Neto, 2013, p. 106-107).

In this sense, Brazil has presented a series of measures in opposition to the traditional measures of democracy promotion and to treatment of the so-called fragile states and peacekeeping in these countries in which they are traditionally carried by the developed states and the United Nations, as like as the presented in the last chapter. Adriana Abdenur and Charles Call (2017) argue that the Brazilian policy on peacebuilding offer an especially well-articulated example of rising powers' approach to peacebuilding. This Brazilian policy is centered on 4 main principles: (1) solidarity; (2) demand-driven cooperation; (3) non-conditionality and; (4) non-interference. It is also noted that these principles were reinforced by 
Brazilian initiatives in global coalition building, especially with other rising powers (p. 9-10).

In this context, Brazil goes beyond the framework of failed states with the argument that each case is a case and that the specific local realities must be understood before the adoption of any measures, rejecting the idea that one model fits all realities, an idea that is commonly defended by the developed states. Thus, Brazil argues that the best peacebuilding strategy is not in the creation of conditions for the Armed Forces and police, but in actions that may prelude violence from (re)emerging, such as the creation of structural economic and social development activities. It is also important to note that Brazil presents itself as a model development country with a multicultural society (Roque, 2009, p. 16-17).

Natalye Gembatiuk de Souza (2014) argues that while in the mainstream discourse on the so-called fragile states they are treated as inferior and incapable, in the Brazilian discourse it is observed a different approach, based on horizontality. In this discourse these states are not treated as "in need" of foreign aid, placing the respect for the national sovereignty of these states as a key element. The author also shows that the speeches, notes or bulletins regarding the situation on these states done by the Brazilian authorities are usually neutral. This approach would aim to avoid the perpetuation of existing hierarchies in the international system. A hierarchy that the country would have experienced throughout its history as an international aid recipient. With all this attitudes, Brazil seeks not only to question the top-down approach that is traditionally adopted by the international donors, but also to present a supposedly different one (p. 66-70).

However, it must be noted that some critics argue that Brazil's solidarity strictly targets other governments, regardless of the type of regime (including nondemocratic ones), and of equating national ownership with government decisionmaking, as opposed to a more participatory process, which would include nongovernmental actors and opposition voices to the established government (Abdenur; Call, 2017, p. 10).

A key approach used by Brazil in its peacebuilding strategy is South-South Cooperation (SSC), which is presented as:

"a way of supporting development, creating or strengthening political, economic or cultural ties, negotiating for greater international prominence and still as a source of soft power and credibility on the global stage. The modalities of this 
cooperation are varied (technical cooperation, humanitarian aid, contributions to multilateral funds, peace operations, etc.). In addition to the bilateral dimension, trilateral cooperation is gaining weight, with a partnership between several countries in the South, the North (United States, Japan, England, etc.) and international organizations (World Food Program, Food and Agriculture Organization of the United Nations, among others)" (Muñoz, 2016, p. 9. My translation).

In addition, it should be pointed out that the actors participating in SSC projects are not exclusively governmental, with private companies and civil society actors. The Brazilian Cooperation Agency (ABC), which is part of the Ministry of Foreign Affairs, coordinates the cooperation projects developed by Brazil and many of them have the participation of several other Brazilian Ministries (ibid, p. 9-10).

In sum, it can be said that "the Brazilian way of peacebuilding" constitutes an alternative approach to the one that is commonly widespread by the developed countries and that focuses only on military questions seeing the armed conflict as the only causes of the violence. In this way, the Brazilian approach sees developmental questions as much as important as the ones that are focused by the mainstream peacebuilding strategies. Thus, the Brazilian strategy adopts practices of South-South Cooperation without (or almost without) imposing conditionality, which values the economic and social development, and without stimulating the reproduction of hierarchies. In the military aspect, the peacekeepers must not be only soldiers, but also active actors in processes of social and structural development.

However, it must be noted that Brazil questions neither the values that are present in the liberal peace norm cluster, as presented in the last chapter, nor the problems it identifies as worthy of action. In this way, in accordance with Deitelhoff and Zimmermann (2013), the Brazilian way of peacebuilding can be read as applicatory contestation because it does not represent a contestation of the validity of the norm cluster itself, but only the means through which it is manifested and applied. It must also be noted that the fact that Brazil does not officially use the term fragile states, for example, does not means that the country does not consider them as a treaty to the international security and that they deserve international aid. This fact supports the classification of the Brazilian way of peacebuilding as a kind of applicatory contestation. This situation can also be interpreted through Antje Wiener's $(2004 ; 2007 a ; 2007 b ; 2014)$ theory on norm contestation. Through this lens "the Brazilian way of peacebuilding" can be understood as a dispute over the 
meaning-in-use of the liberal peace norm cluster since the Brazilian approach represents a dispute between Brazil and other actors in the international system about the meaning of the patterns of peacebuilding in unstable contexts.

In sum, the Brazilian approach represents a contestation of the traditional "way" of peacebuilding. However, Brazil does not contests the core values and problems of the liberal peace norm cluster, questioning only certain aspects about how and in which intensity some behaviors (mainly, humanitarian interventions and international cooperation) are carried out by the developed states and international organizations. This fact makes possible to frame Brazil's approach on peacebuilding not only as an applicatory kind of contestation, but also as a different meaning-in-use of the liberal peace norm cluster rather than the mainstream one.

\subsection{CONCLUSIONS}

The present chapter intended to explore the Brazilian engagement in the discussion on norms and practices of peacebuilding and to present the so-called "Brazilian way of peacebuilding". To do so, a brief historical explanation about the Brazilian insertion in the global debate on norms of international security was made as well an explanation about the guiding principles of the country's foreign policy. After that, the historical Brazilian contribution to UN peacekeeping and the "Brazilian way of peacebuilding" itself were presented.

It was observed that Brazil produces a rhetoric in which its peacebuilding approach differs from the ones that are captained by the NATO, United States and United Nations, for example, and is considered the mainstream approach on peacebuilding, which focuses mainly in military-handed questions. However, it was observed that although the Brazilian approach in fact presents different measures to end the violence in unstable environments, focusing on developmental and sociocultural question, it could also be framed within the liberal peace norm cluster. The fact that Brazil does not use the vocabulary of "fragile states" does not mean that the country does not consider them as a threat to the international security, for example.

Having this in mind, through the theoretical lenses from Deitelhoff and Zimmermann (2013) and Antje Wiener (2004; 2007a; 2007b; 2014) it was argued that "the Brazilian way of peacebuilding" is both a kind of applicatory contestation 
on the liberal peace norm cluster and a meaning-in-use from this norm cluster different from the mainstream one. The next two chapters will present case studies in which the Brazilian approach on peacebuilding are visible and which were a kind of laboratory for the establishment of this Brazilian policy: Haiti, a country in which Brazil had an important role in the UN peacekeeping mission deployed in this country and; Guinea-Bissau, a country in which Brazil has several cooperation projects and whose specific configuration within the United Nations Peacebuilding Commission (PBC) is presided by Brazil. 


\section{THE BRAZILIAN WAY OF PEACABEUILDING: THE HAITIAN EXPERIENCE}

The previous chapter held a discussion on Brazilian diplomatic traditions related to the issue of security, especially on intervention issues and the principles that, historically, guide Brazilian foreign policy on such issues. In addition, the idea of the "Brazilian way of peacebuilding" was presented in theoretical terms, with the differences of the Brazilian approach to approaches considered as "traditional".

Thus, the present chapter aims to analyze how the Brazilian way of peacebuilding takes place on the ground. In this way, an investigation will be carried out on Brazilian practices within MINUSTAH that are different from traditional practices. Also, over the next few sessions, the chapter seeks to defend the hypothesis that the Brazilian role in MINUSTAH played an important role in enabling the concept of stabilization to be considered as a new standard for PKOs.

To do so, this chapter is structured as it follows: Firstly, the history of Haiti from its discovery to the fall of Jean-Bertrand Aristide's government is presented briefly in order to present the political, social and economic context in which the country found itself moments before the establishment of MINUSTAH. Secondly, the post-Aristide scenario is presented along with the political dynamics that led to the creation of MINUSTAH. Also within this session, the Brazilian action to include certain points in the mandate of the mission and the decision of accepting not only to be part but also to command the mission are explored. The third session presents precisely the practices performed by the Brazilians in Haiti, which assisted in the formulation of the term "Brazilian way of peacebuilding". It is argued that the Brazilian way of peacebuilding is not a radical challenge to "traditional" practices, but rather a contestation to the application of the norm of stabilization. Finally, the conclusions obtained during the development of the present chapter will be presented. 


\subsection{A BRIEF HISTORY OF MANY YEARS OF STRUGGLE: HAITI FROM COLUMBUS TO ARISTIDE}

To understand the political crises that emerged in Haiti in the last four decades it is first necessary to understand the history of the country itself. Vanessa Matijascic (2010) argues that we must always refer to relevant historical aspects in order to have a global understanding of the processes that have resulted in the fragility of the country's institutions, in the historical heritage of social segregation and in chronic economic dependence (p. 1). It is precisely within this context that the next few pages aim to present the history of Haiti from Colombo to the fall of Aristide. The events that occurred after the fall of Aristide to MINUSTAH will be dealt with in the next subsection.

The island on which Haiti is located was where the arrival of the Spaniards was established in the "New World" in 1494. Christopher Columbus placed a cross signaling that the lands belonged to the Kings of Castile and baptized the island as Hispaniola. It was also expressed the interest of subjugating the natives of the island, imposing them European customs. The lands of Hispaniola were considered so fertile that words were not able to express their fertility, being only possible to be verified through observation. The local inhabitants were classified as docile and good at taking orders, working, and whatever else was needed to build villages (Colombo, 2005, p. 77-80).

However, Columbus left 39 settlers who were killed by the local inhabitants of the island. The Spaniards, motivated by the ambition to conquer these lands and extract as much wealth as possible, especially gold, used their modern ships and armaments in this endeavor. Thus, by the year 1522, virtually all the local indigenous population had already been exterminated by the conquerors (ibid, p. 97).

The island of Hispaniola, dominated by the Spaniards, soon aroused the interest of the French who dominated its western portion. In this context, the French and the Spaniards came into conflict over the territorial domination of the island. The conflicts only ceased in 1697 through the Treaty of Ryswick ${ }^{18}$, which divided Hispaniola between the two regions: The eastern region was called Santo Domingo,

\footnotetext{
${ }^{18}$ Available in French at: <http://opil.ouplaw.com/view/10.1093/law:oht/law-oht-21-CTS453.regGroup.1/21_CTS_453_fra.pdf>. Accessed on: 12 Aug 2018.
} 
which would be ruled by the Spaniards, and the western region was called Saint Domingue, which would be ruled by the French. Saint Domingue became the "Pearl of the Antilles", the richest and most prosperous colony of the New World, thanks to the high productivity of sugarcane, which was superior to any other country in the region. This production was used by the Napoleonic Empire to pay for the wars of conquest. The labor force was essentially composed of slaves, mostly brought from Africa after the mass extermination of the natives of the region (Verenhitach, 2008, p. 20).

At the end of the XVIII century the Haitian society was essentially composed of two castes. The first and largest was the negro caste, which was composed of individuals from distinct African tribes and their descendants. The second and smaller was the mulatto caste, which was composed of the sons of white men with slaves. Individuals of this caste were commonly sent to France to study and then returned to Haiti. In addition, the mulattos held the means of production and slaves, as like as the few whites who also resided there, constituting a powerful economic and cultural force. This structure generated a continuous class struggle in Haitian colonial society. In this way, the French Revolution (1789) was an important event for the Haitian history (ibid, p. 20-21).

In this context, at the end of the XVIII century, a slave rebellion led by Dutty "Zamba" Boukman, an important Jamaican voodoo priest, fought against Napoleon's imperial army in favor of liberation from colonial rule. The European powers feared that revolutionary ideals might spread throughout the New World. In this sense, the French had the support of the Spanish. In addition, the mulatto caste supported a French expedition aimed at keeping the island under French rule and the slave system. In this context, a Civil War between the two castes emerged in 1791 (ibid, p. 21).

In the year 1793 the revolt began to be led by Toussaint L'Ouverture who refused to make agreements with the white elite and proclaimed himself leader in the name of freedom, equality and the revenge of his race. Thus in 1794 the movement commanded by L'Ouverture, although the western portion of the island of Hispaniola continued under French rule, conquered the abolition of slavery. However, L'Ouverture faced resistance from the mulatto caste, which attempted to gain control of the island. Over the time he lost political strength, besides being a fundamental political actor in the enactment of a new constitution in the year 1801 . 
After a revolt led by his nephew Hyacinthe Moïse, Toussaint was captured by Napoleonic troops in 1803 and taken to the Fort de Joux prison, located in the French Alps, where he died in the same year (Duarte; Queiroz, 2016, p. 28-29; Fonseca, 2011, p. 56).

With the arrest and consequent death of Toussaint the revolution came under the command of General Jean-Jacques Dessalines, who was also a former slave, and in 1804 expelled the 43,000 soldiers of Napoleon's army who occupied the island and declared the independence of the western part of the island of Hispaniola, giving the new country the name of Haiti. Thus Dessalines was the first Haitian head of state and was crowned emperor, just as Napoleon had done after succeeding in the French Revolution (Assunção; Vieira, 2006, p. 2; Duarte; Queiroz, 2016, p. 29; Fonseca, 2011, p. 56).

The independence and abolition of slavery in Haiti were of great concern to both the great European colonial powers and to the United States, fearing an explosion of similar movements throughout the Americas. On the other hand, the Haitians feared a new colonization and took the eastern part of the island, which was a Spanish colony, massacring all Europeans of the region. Thus, the island of Hispaniola remained under Haitian rule until 1844 when the Dominican Republic declared independence, occupying the eastern part of the island. (Verenhitach, 2008, p. 21-22).

However, maintaining Haiti's independent status depended on the recognition of its independence by foreign powers. The United States did not do so until 1862. Jean Pierre Boyer, then governor of Haiti, accepted a French levy and paid them an indemnity of 90 million gold francs for fear of a reconquest by France. This debt strangled the Haitian economy that was already fragile because of the lack of its own resources for sugarcane production to continue and for the high expenditures in the liberation wars of the country and the region. Having its political life marked by coups and counter-coups and consequent social conflicts Haiti maintained its sovereignty until 1915 when, no longer being able to handle the crisis, requested support from the USA, which at the time was applying the Monroe Doctrine and sent the first troops to Haiti on July 28 of that year (ibid, p. 22-23).

For almost twenty years the American troops remained in Haiti, reestablishing the hegemony of the mulattoes. During this period, there was a reasonable progress in living conditions in Haiti. With a certain economic stability, 
schools and hospitals could be built, just as great public works were carried out, such as the National Palace. With public finances being ordered, a timid economic modernization was initiated with the introduction of a few transnational corporations. The occupation ended in 1934 because of the good-neighborly policy conducted by the United States during the Franklin Roosevelt presidency (Seitenfus, 1994, p. 35).

In 1946 there was a general strike in Haiti caused by the bad conditions of life in the country, especially the lack of jobs. The Legislative Chambers were dissolved by the military, which also and seized power. In this context, the so-called Duvalier Age begins with the arrival of François Duvalier, who was followed by his son, Jean-Claude. François Duvalier, who was a doctor, was elected president on September 22, 1957 initially for a term of six years. Its longevity and the brutality with which the Haitians themselves were treated, especially, of course, the opponents of the government characterized his regime were fundamental characteristics of its government. In spite of some economic progress, obtained from the export of textiles, sporting artifacts and tourism investments, the Duvalier dictatorship devastated the country, in addition to having committed numerous violations of human rights (Verenhitach, 2008, p. 23-24).

François Duvalier, who was better known as Papa Doc, decreed a new constitution and declared himself the country's lifetime president in 1964 . He formed a personal militia whose members were known as Tonton Macoutes. They were responsible for terrorizing opposition to the regime, spreading chaos and fear among the majority of the population. After Papa Doc's death in 1979, his son, JeanClaude, who became known as Baby Doc, took the power at the age of 19. Baby Doc also declared himself president for life. However, his dictatorship was gradually weakened by his inability to please the elites and manipulate the military. On February 7, 1986, Haiti suffered a new military coup, this time led by the General Henri Namphy. Baby Doc went into exile in France, leaving Haiti chaotic, violent and with a huge political vacuum (ibid, p. 24).

Over the following three years there was a power struggle involving the military and the Tonton Macoutes, resulting in countless deaths of civilians. Haiti was in a state of chronic political instability and was also facing a chaotic socioeconomic situation. The growing wave of violence, triggered by the coup d'état, mobilized international authorities to intervene in the country in order to establish 
a secure environment and organize elections, which would be held in a peaceful and democratic manner. During that time, a transitional government that decreed a new Constitution in the year 1987, which is still in force, governed the country (ibid, p. 24).

Postponed for countless times the election was finally held in December 1990. The main candidate was the salesian priest Jean-Bertrand Aristide, follower of liberation theology, founder of the Fanmi Lavalas party, popularly known as Lavalas. Because of his religious office, Aristide had had wide support from the population for years and was a personification of the hope and possibility of a new, democratic and human-rights-hailing Haiti. Thus, he was presented as being more than just a political candidate. His campaign was marked by his eloquence and his populist appeal and thus connected him to the people, who were tired of oppression and suffering. Its main motto was to enable the country's population to leave a stage of misery unworthy to that of a worthy poverty. With his strong population support, Aristide wins the election by beating the candidate Marc Bazin, who represented the Haitian elites and had the United States supporting him. Aristide's inauguration is regarded as the first democratic experience in the Haitian history (Seitenfus, 1994, p. 39).

However, Aristide suffered a military coup led by General Raoul Cédras on September 30, 1991, just seven months after assuming the presidency. In that context, Aristide went into exile in the United States and called for support from the international community to assist in resolving the crisis and restoring its mandate. The Organization of American States (OAS) intervened in Haiti through a monitoring joint mission with the UN in 1993 (International Civilian Mission in Haiti) that intended to constrain human rights violations through its own presence, but the crisis continued to evolve internally. The joint mission lasted in Haiti until 1994, year in which international observers were expelled. Thus, there has been an unbridled increase in violence, countless human rights violations and the worsening state of misery of the majority of the population. After the displacement of the center of gravity of the Haitian crisis leaved the democratic question and migrated to the humanitarian issue, the UN became fundamental in the context of the Haitian crisis. The UN and the OAS supported an economic embargo designed to destabilize the military government but, as a consequence, ended up drastically 
disrupting the already fragile institutions and economy of the country (Seitenfus, 1994, p. 14; Valler Filho, 2007, p. 147; Verenhitach, 2008, p. 25-26).

In this way, the United Nations Security Council was activated and for the first time in the Americas, the controversial Chapter VII of the Charter of the United Nations was implemented through the Resolution $940^{19}$, which established the creation of an international force composed of about twenty thousand soldiers. This measure was carried out due to this framework of repression and human rights abuses, with the bankruptcy of the OAS political and diplomatic measures and also by the lack of enforcement that the multilateral mechanisms of economic and commercial pressure had (Valler Filho, 2007, p. 147; Verenhitach, 2008, p. 26).

It is worth noting that between 1993 and 1994 Brazil occupied a nonpermanent seat in the United Nations Security Council, but abstained in the vote on Resolution 940 and also on Resolutions $944^{20}, 948^{21}$ and $964^{22}$, which also dealt with the subject in the same year. However, the international military force resulted in the unprecedented fact of through the participation of the international community, a deposed president was put back in power. In this context, Aristide was reinstated to the presidency and dissolved the Armed Forces in the year of 1995, counting on the support of the United States (Valler Filho, 2007, p. 147).

For the 1995 election, Aristide supported the candidacy of René Préval, who was elected for a five-year term since the Haitian constitution closed the re-election and allowed only one candidate to assume the presidency again after five years, third term. Thus, Préval remained in power only awaiting the return of Aristide, leaving the country practically immobilized during his term. During Préval's presidency, Haiti received four United Nations civilian and military missions ${ }^{23}$. However, all failed. It should be noted that although they had varied durations and mandates, the attempt to neutralize the Haitian crisis was the main objective of these missions. Actions for the professionalization of the Armed Forces and training of

${ }^{19}$ Available in English at: <https://undocs.org/S/RES/940(1994)>. Acessed on: 13 Aug 2018.

${ }^{20}$ Available in English at: <https://undocs.org/S/RES/944(1994)>. Acessed on: 13 Aug 2018.

${ }^{21}$ Available in English at: <https://undocs.org/S/RES/948(1994)>. Acessed on: 13 Aug 2018.

${ }^{22}$ Available in English at: <https://undocs.org/S/RES/964(1994)>. Acessed on: 13 Aug 2018.

${ }^{23}$ The four missions were: United Nations Mission in Haiti (UNMIH), that remained in the country between September 1993 and June 1996; United Nations Support Mission in Haiti(UNSMIH), that remained in the country between June 1996 and July 1997; United Nations Transition Mission in Haiti (UNTMIH), that remained in the country between August 1997 and November 1997 and; United Nations Civilian Police Mission in Haiti (MIPONUH), that remained in the country between December 1997 and March 2000 (Verenhitach, 2008, p. 35-36). 
the Haitian National Police were also carried out on all missions, but also did not achieve much success (Verenhitach, 2008, p. 26-27).

The 2000 elections in Haiti came under heavy accusations of fraud and high pressure from various groups in the country. Jean-Bertrand Aristide was re-elected for a second term as president of Haiti. It should be noted here that Aristide was elected with $60,5 \%$ of the votes and the Brazilian Embassy in Port-au-Prince informed the Ministry of Foreign Affairs in Brasilia in a telegram that only 2 million voters would have voted. This number represented, for the opposition leaders not even $5 \%$ of the total number of registered voters, thus representing a strong indication of electoral fraud (Valler Filho, 2007, p. 148; Verenhitach, 2008, p. 27).

Following the establishment of the new House of Representatives and the renewal of two-thirds of the seats of the Senate, the ruling party, Fanmi Lavalas, became a majority and again accusations of vote-rigging were registered that were endorsed by representatives of the international community. With this, international aid was once again suspended and once again the already fragile economy of the country lost precious resources. Despite the efforts of international mediators, there has been increasing political polarization, with the recruitment of popular organizations for purposes of violence, the primacy of personal interests over collective interests and acts of insurrection (Valler Filho, 2007, p. 149).

It should also be noted that in the pre-electoral period of 2000 the emergence of the chiméres, a group of supporters of Aristide, was observed. The group was composed of several civilian armed groups that were formed before the incapacity of minimum guarantees of survival of the Haitian state. They were accused of using violence and being an unofficial armed wing of Aristide, just as the Tonton Macoutes were with Duvalier. Amid police inertia, groups in Bel Air and Cité Soleil, supporters of Aristide, have also been accused of stopping opposition rallies as well as planning and executing attacks on politicians, human rights activists and journalists (Silva, 2016, p. 51-52).

During his second presidential term, Aristide faced opposition from four main groups: (1) The Group of 184, a group made up of sectors of civil society whose financial resources were of foreign origin; (2) the hybrid opposition, whose only common point among its members was the defeats for Préval and Aristide; (3) the students of the Public University and; (4) a group of former military personnel. The main opposition group to Aristide, the Group of 184, was led by the industrialist 
André Apaid, and found the consensus needed to sign a communiqué aimed at initiating a broad reflection with a view to the elaboration of a "new social contract" contemplating political alternatives for the Haitian crisis. This group brought together about 300 Haitian civil society entities, including businessmen, employers' and labor unions, the press, students, civil and religious organizations. It was the first political group, in 200 years of Haiti's independent history, to bring together different opposition chains, representing local elites (Valler Filho, 2007, p. 149; Silva, 2016, p. 52).

As much as Aristide's supporters, the opposition also used violence as a political weapon. Invasions of police stations in 2001 by unidentified groups, and the invasion of the presidential palace by the ex-military group, demonstrated that Haiti was in an extremely delicate political situation. The end of the Armed Forces caused a great amount of free weaponry to fall into the hands of several groups. Thus, both Aristide support and opposition groups have easier access to arms, increasing crime. Although the purpose of the end of the Armed Forces was to eliminate the risk that they offered to Haiti's political stability, the absence of concrete measures to ensure that this occurred in an orderly manner created a new problem for the country (Silva, 2016, p. 52).

However, despite the entente made up of various segments of civil society, violence only increases, at that time with multiple popular manifestations demanding the resignation of Aristide. In early December 2003, governmentfriendly student groups and opposition groups met at the University of Port-auPrince. However, the clashes have spread, leading to popular clashes on the streets of the capital. It is worth noting that the National Police did not took any actions to contain the disturbances and the crisis led to the resignation of the Minister of Education (Valler Filho, 2007, p. 149-150).

In June 2003, members of the Lavalas Party began discussing the need to convene the elections for the end of the year in order to prevent what they called "institutional vacuum" as most parliamentary mandates would end on January 12, 2004. The issue was not resolved and the legislative elections scheduled for 2003 were not held as the opposition refused to participate in the electoral process and did not appointed representatives to serve on the Provisional Electoral Council, which would be responsible for organizing and promoting the elections. The Haitian Parliament, due to the absence of legislative elections and the end of the 
mandates of the majority of its members, practically ended its activities in January 2004. From then on, the Executive proceeded to legislate by means of decrees, in accordance with the national constitution (ibid, p. 150).

Wladimir Valler Filho (2007) argues that:

"The ineffectiveness of the model of Haitian democracy is mainly due to the unrealistic number of elections for the different levels - national, departmental, municipal and legislative - foreseen in the electoral calendar and the requirement of passing three legislatures, about nine years, for the approval of any change in the Constitution" (p. 150. My translation).

The disputes became increasingly intense and violent. In the central province, groups of ex-military, financed by wealthy Haitians began to act with the aim of killing supporters of Lavalas. The reaction against the opposition was no less violent. In the city of Gonaives, for example, the Haitian National Police violently suppressed a rebellion causing deaths of women and children. Thus, faced with the escalation of violence, the Caribbean Community (CARICOM) proposed an agreement. Although accepted by Aristide on January 31, 2004, it was rejected by the opposition, which demanded his removal from the presidency. On February 5, the group Front de Resistance l'Artibonite pour le Renversement pour le Renversement de Jean-Bertrand Aristide took the city of Gonaives, causing the Haitian National Police to leave the city (Silva, 2016, p. 52-53).

On February 21, 2004, a new commission made up of representatives of CARICOM, Canada and the United States attempted to sign a new agreement in order to put an end to hostilities and provide conditions for dialogue between the groups involved and the sharing of power. Although Aristide accepted the agreement, once again the opposition refused to abide by the pact. For the opposition the resignation of Aristide was the only way to solve the problems of Haiti (Escoto, 2009, p. 40).

In the first hours of February 29, 2004, Aristide resigned, for the second time, to the presidency of the country. Immediately after his resignation, he and his wife were taken to the Central African Republic by a United States Armed Forces aircraft, accompanied by security personnel and US military. On the other hand, in Haiti, many members of Lavalas were arrested, killed or tortured. Another significant portion of Lavalas members opted to flee the country, especially to the Dominican Republic. The circumstances surrounding the fall of President Aristide 
remain unclear to this day. There are suspicions that the former president would have been forced to resign, notably by the US and French governments, also counting on support from Canada. There are also unconfirmed suspicions that the Armed Forces would have forced Aristide to leave the country. This coincides precisely with the version of Aristide, who claims to have been taken by force, typifying the action as a coup d'Etat. It is worth noting that CARICOM, the African Union and the Congressional Black Caucus organization condemned the coup and did not recognized the interim government, which was taken over by Gerard Latortue (Verenhitach, 2008, p. 28-30).

\subsection{THE POST-ARISTIDE SCENARIO AND THE ESTABLISHMENT OF MINUSTAH}

At the time of Aristide's fall, Haiti was perceived as a fragile state by the international community and faced a series of political, economic and social problems. The Haitian crisis that began in 2004 was considered a continuation of the crisis that devastated the country in the 1990s. However, none of this would be so serious if the historical context and geographical characteristics were different. Social and human indicators were alarming at the epoch. Of the total population of 9,597,851 inhabitants (census of 2007), 61,2\% resided in the rural areas of the country. In addition, the population presented an annual growth rate of $1.62 \%$. The Human Development Index (HDI) was 0.52 (Dominican Republic's HDI, located on the same island, was 0.75 ). The literacy rate (inhabitants 15 years of age and older) was only $52 \%$, and $46 \%$ of the population was considered undernourished. Until the year 2004, only $54 \%$ of the households had access to potable water and only $30 \%$ to the sanitary network. The unequal income distribution generated even more socio-economic problems, since only $20 \%$ of the population received $68 \%$ of the national income (Verenhitach, 2008, p. 31-32).

In the afternoon, following the Haitian constitution, the transitional government was assumed by the then President of the Supreme Court of Justice, Boniface Alexandre, who adopted as his first measure the request for international support for the maintenance of order in the country. Thus, on 29 February, the Permanent Representative of Haiti to the United Nations submitted a copy of 
Aristide's resignation letter and a request for assistance to the Security Council (Valler Filho, 2007, p. 153).

Thus, on February 29, the United Nations Security Council (UNSC) adopted Resolution $1529^{24}$ establishing the Interim Multinational Force (IMF), with the indication of the future establishment of a Peace Mission. The Brazilian vote was given to the IMF, although Brazil did not contribute troops with the argument that the Mission would be under the aegis of Chapter VII, which was in line with the Brazilian tradition of not participating in peace enforcement missions. In the meantime, Brazil's willingness to participate in "subsequent moments" of a peacekeeping mission based on Chapter VI, according to the historical tradition of its participation in PKOs, was signaled (Bracey, 2011, p. 318; Fontoura; Uziel, 2017, p. 10).

It is worth noting that the IMF was not a mission of peace itself. Its members therefore did not wear the blue helmet, which is characteristic of United Nations peacekeeping troops, but military uniforms from their countries of origin (mainly, United States, France, Chile and Canada). The IMF was established on the basis of Chapter VII of the UN Charter and was intended primarily to ensure a secure and stable environment and to ensure law and order and protection of human rights in Haiti for a maximum period of three months. The IMF managed to keep violence at acceptable levels, bringing some stability to the country, preventing institutions from collapsing. Throughout its activities, the UN began planning and negotiating a peacekeeping mission to Haiti (Verenhitach, 2008, p. 36-37).

Thus, over the next two months, the mandate of the mission that would replace the MFI was negotiated within the framework of the United Nations. Throughout the negotiations, Brazilian diplomacy worked hard to ensure that the new Mission in Haiti would not be considered as an extension of US foreign policy. MINUSTAH was created with the launch of Resolution $1542^{25}$ on April 30 and some Brazilian demands were met, such as the mention of development aid, fight against hunger and the strengthening of local autonomy. Although MINUSTAH's initial mandate included few Brazilian development support demands, this aspect has gained momentum over the years and has become more consistent within the mandate of the mission (Fontoura; Uziel, 2017, p. 10).

\footnotetext{
${ }^{24}$ Available in English at: <https://undocs.org/S/RES/1529(2004)>. Accessed on: 25 Aug 2018.

${ }^{25}$ Available in English at: <https://undocs.org/S/RES/1542(2004)>. Accessed on: 26 Aug 2018.
} 
However, it is important to note that despite Brazilian efforts, the Resolution 1542 also mentioned Chapter VII, a fact that, in theory, would not allow the country to send troops to Haitian soil in accordance with its non-interventionist tradition. However, Brazilian diplomacy, in order to justify the Brazilian acceptance of not only sending troops, but also to exercise the military command of the mission, argued that only the seventh paragraph of the Resolution was supported by Chapter VII and not the document as a whole. This fact constitutes an interpretive subtlety that revealed a greater disposition of Brazil's foreign policy to act in a more aggressive and pragmatic way in the post-Cold War period and the importance that the PKOs and especially MINUSTAH would come to have in the so-called “Brazilian Great Strategy” (Alsina Júnior, 2017, p. 7-9; Bracey, 2011, p. 318-319).

\subsection{MINUSTAH AND BRAZILIAN PEACEBUILDING PRACTICES}

As presented in the previous chapter, Brazil has a long engagement with United Nations peace operations. However, MINUSTAH represented a new chapter in this history, not only by the high number of Brazilian soldiers who were displaced to the mission, a number that according to Ronaldo Mota Sardenberg (2017) reaches 37500 (p. 4), but also by the Brazilian military leadership of the mission.

However MINUSTAH was composed of military contingents from more than 10 countries (including Bangladesh, Chile, Philippines, Uruguay and Argentina), Brazil was the country that most sent troops to Haiti during the duration of the mission between the years 2004 and 2017. The Brazilian contingent (CONTBRAS) was initially composed of an Army Infantry Battalion (BRABATT) and a Marine Operations Group. This structure was maintained until the arrival of the third contingent, which further incorporated an Army Engineering Company (BRAENGCOY), which initially had about 150 men and in 2008 was increased to 250 (Mendonça, 2017, p. 59). It is worth noting that, as will be presented later, BRAENGCOY proved to be important for practices of the "Brazilian way of peacebuilding" in Haiti.

According to the Brazilian Army Colonel Marcos Mendonça (2017), the pacification of greater Port-au-Prince, one of the great objectives of MINUSTAH, can be summarized as follows:

"1st Phase (2005): Pacification of Bel Air (3rd CONTBRAS); 
2nd Phase (2006): Pacification of Cité Militaire (5th CONTBRAS);

3rdPhase (from 2007 to 2014): Pacification of Cité Soleil (6th to 22nd CONTBRAS);

4th Phase (from 2007 to 2010): Maintenance of stability and security in the area of the CONTBRAS and suffocation of gangs in the area of responsibility of BRABATT.

5th Phase (from 2010 to 2014): reconstruction of the security environment deteriorated by the earthquake (2010), focusing on Cité Soleil" (p. 60. My translation).

In addition to the pacification of areas in Haiti, it should be noted that the mission since its inception was already fulfilling the other objectives of the mandate. Since 2006, for example, there has been a guarantee of free and secure elections, with broad popular participation (ibid, p. 60).

In practical terms, what can be observed during the 13 years of MINUSTAH was that the Brazilian work combined aspects of peacekeeping missions as well as aspects of the "Brazilian way of peacebuilding". Regarding peace enforcement actions, perhaps the most emblematic case was the so-called Bel Air pacification in 2005, carried out by men from the Brazilian Army with support from the Haitian National Police (HNP). In the actions to combat criminal activities and to carry out the pacification process of Bel Air, a poor and peripheral area of Port-au-Prince that was dominated by armed gangs, the Brazilian contingent used robust military force to fight against armed groups and individuals. For this purpose, legal protection was sought in chapter VII of the Charter of the United Nations, as described by Division General André Luis Novaes Miranda (2017):

"The normative support was derived from Chapter VII of the Charter, in which the MINUSTAH Mandate was based on, derived from Security Council Resolution 1542, which assigned the forces the task of ensuring the security and stabilization of the country, providing operational support to the HNP and protection of threatened civilians, among others. In addition, the Brahimi Report already defined "spoilers" and called for peacekeeping to defend civilians. And, finally, the SOFA (Status of Force Agreement) guaranteed freedom of movement to troops throughout Haiti. Acting within this framework, the Haitian Battalion had no other recourse but to use the necessary and proportional force to release roads blocked by the adverse forces and to act against armed groups that had victimized civilians in its area of responsibility. It also had to respond in a timely manner to various armed actions against its own forces (111 of them recorded in the daily documents sent to MINUSTAH's command only in the $3^{\text {rd }}$ Contingent). Thus, each time the bases of these groups were identified, the battalion troops, usually acting in conjunction with the HNP, organized operations for their dismantling and arrest of bandits, and employed adequate and 
proportional force whenever there was resistance to the progression of their groups. Over time, this was no longer necessary and these people preferred to escape from confrontation" (p. 53. My translation).

Gabriela Verenhitach (2008) argues that one of the main characteristics of the Brazilian performance at the head of MINUSTAH was precisely the dialog and respect for the population and local authorities that permeated the establishment of strategies and their execution by military force. It should be noted that General Augusto Heleno, the first MINUSTAH force commander, when he took office in Haiti, said that he was there representing the United Nations to work with the Haitian population and authorities, in a complete integration of forces to aid in the reconstruction from the country (p. 80).

It was precisely within this context that on August 18, 2004, just over 4 months after the establishment of MINUSTAH, the so-called "Match for Peace", a friendly football match between Brazil and Haiti, was held. The football match was carried out by an initiative of the Brazilian Ministry of Foreign Affairs in an effort to bring the Brazilian and Haitian peoples closer together and win the support of Haitians to the actions carried out by Brazil in the context of MINUSTAH (ibid, p. $81)$.

After discussions about the Brazilian participation in the mission, the Brazilian president Luiz Inácio Lula da Silva proposed to the Brazilian Football Confederation $(\mathrm{CBF})$ to hold a friendly match in Haiti to start a campaign of disarmament. Although the CBF liked the idea, and it was also accepted by the International Federation of Association Football (FIFA), some clubs in which important players of the Brazilian team played (Kaká, Dida, Cafu and Zé Roberto at AC Milan and Bayern München, for example) were not pleased with the initiative and prevented their players from playing the friendly game. The Brazilian squad landed on Haitian soil only two hours before the game and was taken to the site of the game in Urutu armed personnel carriers. The way from the airport to the place of departure was like a parade of champions in the open, with thousands of Haitians around the Brazilian players (Pimentel, 2016).

The match took place at the Sylvio Cator Stadium in Port-au-Prince, and took to the streets an uncountable crowd of Haitians who cheered not only the players but also the Brazilian authorities. Of the 2500 soldiers who patrolled the Haitian capital for the game, 1200 were Brazilians. A total of 13000 Haitians 
watched the game at the stadium while many others took to the streets to watch the game on 50 29-inch televisions that have been set up in schools, crèches and orphanages specifically for the game and on hundreds televisions scattered in bars and restaurants (Agência Estado, 2004).

The Brazilian military advised the organization of the match that weapons could be exchanged for tickets. However, the idea was not feasible and was not put into practice. In any case, it was argued that withdrawing a weapon could be far less effective than disarming the spirits of Haitians. In this sense, the Brazilian players would have contributed more by showing other athletes around the world that it was possible to play only for peace. The final result of the match (6-0 for Brazil) was extremely celebrated by the hosts since they never imagined receiving the Brazilian team, five-time champion of the world, at that moment (Agência Estado, 2004; Pimentel, 2016).

The Brazilian attitude of organizing a friendly football match against Haiti represented one of the first unconventional peacebuilding measures that would be implemented by Brazil throughout MINUSTAH. The "Match for Peace" represented a gesture of cultural rapprochement between the two countries, a nonconventional Brazilian initiative to "win the hearts and minds" of Haitians and, above all, a gesture of goodwill from Brazil in actively collaborating for the establishment of peace and truly democratic institutions in the country.

Adriana Abdenur and Charles Call (2017) note that throughout the entire MINUSTAH mandate (2004-2017) Brazil pressed for authorization to use UN peacekeeping resources, which are commonly restricted to funding peacekeepers and their operational needs, on development and peacebuilding-oriented programs in Haiti. In this context, in the Security Council and in the Administrative and Budgetary Committee of the General Assembly of the United Nations, that deals with budgetary issues related to peacekeeping, Brazilian diplomats pushed for the so-called quick impact projects $\left(\mathrm{QIPs}^{26}\right)$ and community violence programs for

26 “Quick Impact Projects (QIPs) are small-scale, low-cost projects that are planned and implemented within a short timeframe. Different actors beyond peacekeeping also fund or implement QIPs with varying objectives. (...) The objective of QIPs is to build confidence in the mission, the mandate or the peace process. While QIPs should always benefit the population, they are not intended to be humanitarian or long-term development support. However, good coordination with development and humanitarian actors is essential to ensure that projects do not duplicate or undermine their work. It is important to keep in mind the distinct character and confidence-building objective of QIPs throughout the project cycle. The confidence-building objective may influence the choice of implementing partner, the 
Haiti. Thus, approximately \$5 million annually were allocated to these QIPs. One example that combined elements of development and peacebuilding coordinated by Brazilian troops was the "Light and Security" initiative that installed solar lampposts in the most vulnerable parts of the capital, making those areas safer at night (p. 13).

In addition, it is stated that some attitudes that were not foreseen in the United Nations manuals of action were carried out by the Brazilian troops in Bel Air and facilitated a successful change in the support of the local population towards the mission. Among these actions it is possible to highlight the withdrawal of sunglasses by Brazilian soldiers to enable greater visual contact with the local population, the exit of the soldiers from the armored vehicles to walk in the streets and the realization of dialogues with the inhabitants of the locality. It is also important to note the presence of social projects carried out by Brazilians is also considered as a factor that influenced the support of the population of Bel Air to the actions of the Brazilian contingent (ibid, p. 14-15).

The Brazilian Corps of Engineers also helped to drill wells, build bridges and dams, and carry out slope stabilization in landslide-prone areas. Brazilian diplomats argue that the Brazilian military engineers pushed the boundaries since the UN Secretariat would not let them repair roads too far from the battalion base. So, BRAENGCOY brought in their own asphalt manufacturing capability and used Embassy funds to pay for road repairs elsewhere. In many of these initiatives, Brazilian troops built upon the development-oriented activities that the Brazilian Armed Forces carry out domestically in remote areas of the Amazon and border regions. The rationale was that, by contributing toward basic infrastructure, Brazil could not only help with infrastructural issues but also boost development and help mitigate some of the factors leading to recurring instability (ibid, p. 13-14).

Lieutenant General Floriano Peixoto Vieira Neto (2017) argues that Haiti, until January 12, 2010, was a country that recorded one of the most successful examples of a PKO, especially according to the military and UN personal. In fact, it is commonly argued that the country was ready to go forward, in a self-sustaining

identification and selection of projects, the impact assessment and publicity strategies. Clarity regarding the objective of QIPs is essential in communication with partners as it helps to manage expectations and ensure a clear understanding of the limitations" (Coning; Fearnley; Harvey, 2012, p. 224-225). 
way, and some indicators give account of this reality: A completely stabilized security situation; the dismantling of all gangs; professionalization and growth of the Haitian National Police (HNP); maintenance of security control throughout the country; functioning of national institutions; increasing international credibility; electoral process in progress and; human rights situation under absolute control, among others. However, this situation would become radically late that day, leaving the country in a more delicate situation than that encountered by MINUSTAH in 2004. The earthquake generated a great and serious crisis, even in areas that were not reached but that were also affected by the uncontrolled migratory flows that appeared in their direction (p. 19-20).

The military component was used since the first moments after the earthquake and Brazilian troops, because they were majority in Port-au-Prince, epicenter of the earthquake, began to immediately engage in fundamental measures. The Brazilian contingent had not yet accounted for its losses (18 Brazilian soldiers were killed) and was already fully involved in the effort to alleviate the crisis, including adapting the BRABATT base to receive critical injuries. BRAENGCOY was engaged beyond the doctrinal boundaries of employment and thus it remained, even after considerable time after the earthquake, because its effects were still felt in the life of the Haitian population. Thus, BRAENGCOY carried out the removal of bodies from the streets and the rubble and the preparation of places for collective burial, with guidance from the International Red Cross. The contribution of the Brazilian military was considered as fundamental for the establishment of immediate control of the situation, avoiding the occurrence of a generalized disorder after the earthquake (ibid, p. 20-21).

After the earthquake the Brazilian government created a partnership with Viva Rio, a NGO based in Rio de Janeiro, specialized in community peacebuilding and disarmament in urban and poor scenarios in Brazil, to carry out humanitarian and development initiatives in areas of Haiti strongly affected by the earthquake and ensuing crisis. In this sense, this NGO was designated to coordinate a reconciliation program that helped to mediate and promote the dialog between the Haitian national police and leaderships from different parts of Bel Air, Cité Soleil, and Delmas, for example. Viva Rio also received MINUSTAH financing to carry out sports activities and cultural initiatives to strengthen this initiative. It must also be noted that, the Brazilian government provided bilateral technical cooperation in 
social policy areas like public health, agriculture, energy, and capacity-building. Through these different arrangements, the Brazilian government worked to complement the military role of MINUSTAH with initiatives that would promote long-term social well-being and stability (Abdenur; Call, 2017, p. 14).

Despite the successes presented, what can be perceived is that the "Brazilian way of peacebuilding" has also been criticized in Haiti for a number of reasons, among which we can highlight: The non-uniformity of Brazilian actions throughout Haiti ; lack of coordination with stakeholders in Haiti; the need for a heavy military apparatus to carry out the "social" tasks that Brazil performed (ibid, p. 15).

It is possible to note that throughout the Mission, although development initiatives and involvement with the local population were taken, the main focus was the pacification of violent areas in Haiti through policies of military confrontation with crime. Therefore, the objectives of stabilization (promotion of security in multiple levels - physical, individual and state - the constitution and strengthening of political agreements and the creation of conditions of possibility for recovery and reconstruction through a wide range of configurations) were being achieved through a number of development assistance and local empowerment actions diluted in an endless number of heavy military actions, the main means used by Brazil in MINUSTAH for the fulfillment of its mandate.

Thus, some conclusions that can be drawn through this brief presentation of MINUSTAH and the Brazilian performance in Haiti. First, in 2004, year of the establishment of the Mission, the idea of stabilization, even though it had already been adopted by other International Organizations (such as NATO, for example) to classify its missions, was still emerging in the United Nations environment, in search of formal validation, a fact that came with United Nations Security Council Resolution 1524 (2004). Secondly, it can be inferred that the social recognition of this norm by the Brazilian contingent occurred with the acceptance of the use of chapter VII of the Charter of the United Nations and the imposition of peace through the use of force for the fulfillment of the mandate, a fact hitherto rejected by both Brazilian Armed Forces and diplomacy.

From an international point of view, the Brazilian critical-alternative approach to PKOs expressed in MINUSTAH can be considered as an example of an applicatory contestation, as typified by Deitelhoff and Zimmermann (2013). This fact occurs since it can be seen that the "Brazilian way of Peacebuilding" presented 
in Haiti does not present any questioning of the validity of the objectives, mechanisms and tools of the peacekeeping missions, but rather the the application of these concepts in practice. In addition, what can be observed is that although Brazil has presented actions distinct from the common actions to be seen in the stabilization operations carried out by the United States in Iraq and Afghanistan, for example, the objectives and military means used in MINUSTAH are extremely similar.

In addition, it can be said that the Brazilian performance in MINUSTAH helped to legitimize the stabilization norm within the United Nations. As anticipated by Wiener (2004, 2007a, 2007b, 2014) and Deitelhoff and Zimmermann (2013), the Brazilian contestation, focused on the "meaning-in-use" questions of the stabilization norm, assisted in legitimation and, later, in the strengthening of stabilization as a new United Nations Standard for peace operations. This fact can be observed since after the creation of MINUSTAH and its development over the years a further two stabilization missions were created by the United Nations: $\mathrm{MONUSCO}^{27}$ and MINUSCA${ }^{28}$. It is important to note that although MONUSCO was created to replace an existing mission, it was only with its creation that the elements of stabilization were incorporated into the mandate and into peacekeepers' actions. In addition, the recent invitation to Brazil to integrate the military contingent of MINUSCA, which was initially accepted and later refused under citation of financial constraints, reinforces the hypothesis of the important role played by the country in establishing legitimacy for a new type of UNPKO: stabilization operations. Thus, it is proved that by means of the contestation it is possible not only to legitimize and bring to the public debate a certain norm, but also to shape it, to a greater or lesser degree, according to its interests, a fact that can be very much perceived both in Brazil's role in MINUSTAH and in the inclusion of certain aspects included in the mandate of the Mission (fight hunger and development aid, for example) after pressure from the Brazilian diplomacy.

\footnotetext{
${ }^{27}$ Acronym for the French, Mission de l'Organisation des Nations Unies pour la Stabilisation en République démocratique du Congo.

${ }^{28}$ Acronym for the French, Mission Multidimensionnelle Intégrée des Nations Unies pour la Stabilisation en Centrafrique.
} 


\subsection{CONCLUSIONS}

The United Nations Security Council Resolution 1542 (2004) established the creation of a type of peacekeeping Operation that had never been developed before, within the scope of the Organization. The idea of stabilization has been developed by major powers within the context of the post-Cold War era and the mechanisms to combat insecurity in areas of the periphery of the international system and found its first formal use within the United Nations precisely in that Resolution.

In the light of the debate on normative diffusion within the constructivist theories of International Relations, it was possible to identify and classify the Brazilian performance in MINUSTAH, both in negotiating the mandate and in the field, as a normative contestation action regarding the application of the stabilization norm. That is, Brazilian action in Haiti did not contested the objectives and even the means of imposing military force, but sought to reconcile them with actions that are more linked to peacebuilding than to peacekeeping itself, such as development aid through the construction of water wells, roads, bridges and dams by the Engineering Corps of the Brazilian Army, as well as establishing partnerships with Brazilian NGOs, which helped to reconcile community leaders with the Haitian National Police. In addition, the use of sports, music, and cultural activities as a mechanism of reconciliation has been observed, evading the traditional aspect of peacekeeping operations (Abdenur; Call, 2017, p.14).

Therefore, it was possible to conclude that the Brazilian action in Haiti and the normative contestation represented by it helped in the process of democratization of the discussion of the emerging norm and, consequently, in its legitimation before the international community. The creation of two more stabilization missions by the United Nations after the creation of MINUSTAH is a strong indication that stabilization can already be considered as a norm legitimized and socially accepted by the agents of the International System. Finally, it should be noted that although stabilization can already be considered as a legitimate norm, it is still in the process of being built since there are missions currently under way with this character. 


\section{THE BRAZILIAN WAY OF PEACEBUILDING: THE GUINEA- BISSAU EXPERIENCE}

The last chapter aimed to present the presence of Brazil in Haiti through its participation in MINUSTAH and how the Brazilian way of peacebuilding was applied throughout the Brazilian experience in the Caribbean country. In this sense, the process of negotiating the mandate of the mission and the procedures for both civil and military action over the term of mandate were presented. In this sense, the military component of the Brazilian way of peacebuilding was presented as well as its interpretation as a contestation in terms of application the stabilization norm.

The present chapter, in continuity with the previous effort, intends to analyze how the Brazilian way of peacebuilding takes place through South-South cooperation actions in statebuilding environments. In this way, it will be sought to analyze the Brazilian performance in Guinea-Bissau, seeking to understand in which points the Brazilian practices have similarities and differences in relation to those considered as the norm by the international community. This analysis aims to support the hypothesis that through these actions Brazil promotes a contestation in terms of the application of the liberal peace norm cluster, being therefore in accordance with its values and problems and offering differences as to its application.

To do so, this chapter is structured as it follows: Firstly, a brief history of Guinea-Bissau is presented, since many of the problems the country faces today have strong relations with its colonial history and disputes over post-independence period by various political and military factions. Next, the Brazilian actions in Guinea-Bissau are presented and contextualized with other actions of countries of the so-called global north and international organizations with the purpose of precisely exposing the similarities and differences between the different views and ways of statebuilding. Finally, the conclusions obtained during the development of this chapter will be presented. 


\subsection{GUINEA-BISSAU HISTORY}

The history of Guinea-Bissau is strongly linked by international and local disputes. Throughout the $15^{\text {th }}$ and $16^{\text {th }}$ centuries the Portuguese Empire dominated the entire west coast of the African continent. However, this region in the following centuries suffered incursions and attacks promoted by other European imperial powers, especially the English, French and Dutch. In the seventeenth century an administrative region of the Portuguese Empire was established, which encompassed the regions that today correspond to Cape Verde and Guinea-Bissau. It is important to note that the creation and grouping of the regions of Cape Verde and Guinea-Bissau into a single administrative region would later have an important impact on the anti-colonial struggle and the independence of both States with the creation of a party interested in leading the independence of both States and promoting a joint armed struggle.

The year 1878 is marked by the occurrence of a massacre of Portuguese soldiers in Bolor, north of Guinea-Bissau, who were part of the Portuguese expeditionary force in the administrative region. The Bolor attack was intended to expel the Portuguese from the region and had the effect of separating GuineaBissau from the same administrative region of Cape Verde on March $18^{\text {th }} 1879$ (Lobban Jr.; Mendy, 2013, p. 300). However, the bonds between the two societies had already been formed over the period in which they were part of the same administrative region of the Empire.

Over the following years Portugal maintained a policy of soft domination in Guinea-Bissau, with the collaboration of some ethnic groups and local political groups. However, Salazar's arrival in power in 1933 and the establishment of the Estado Novo ${ }^{29}$ in Portugal meant that the effective colonization of the Portuguese overseas territories became a matter of national interest vital to the maintenance of the authoritarian political system. Thus, there was a process of forced labor and exploitation of natural resources of the African colonies, including Guinea-Bissau, for the maintenance of the Estado Novo during this period (Abadia, 2016, p. 115116).

\footnotetext{
${ }^{29}$ Estado Novo was the name given to the Portuguese dictatorial regime that ran from 1933 to 1974, with Antônio de Oliveira Salazar having been the head of government for most of that period, being succeeded by Marcelo Caetano in 1968.
} 
In the period after World War II a policy of "evolution of continuity" for the colonies was established by Portugal. This policy sought at the same time to promote administrative autonomy, social development and to prevent the emergence of anti-colonial forces inspired by the international conjuncture of the period and Guinea-Bissau was used as a "test tube" for this policy, which ran from 1945 until 1948.

In 1951 the Portuguese Colonial Act was revoked, at least legally, promoting the extinction of the Portuguese colonies and transforming them into overseas territories. In practice, the overseas territories would have their own governments and would be considered as provinces, although there was only one party allowed by law throughout the Empire and Salazar himself appointed the governors.

The year 1956 is politically striking for Guinea Bissau, with the creation of the African Independence Party $\left(\mathrm{PAI}^{30}\right)$. However, prior to the creation of the PAI, other lesser-known parties had also been created, but they did not achieved great expression and popular acceptance in their projects. The PAI was founded on September $19^{\text {th }} 1959$ with Amílcar Cabral, an agronomist born in Guinea-Bissau who was educated in Portugal and worked in the Ministry of the Overseas, responsible for the Portuguese colonies, and had a strong Marxist influence in his thinking. The PAI, headed by Cabral, had as main objective the promotion of the independence of Guinea-Bissau and Cape Verde.

The PAI's activities were largely suppressed by the Estado Novo in the urban areas of Guinea-Bissau, forcing the Party to take a more rural course between 1956 and 1960, seeking the support of the local population for the anticolonial cause. In October 1960 the Party adopted the name of the African Party for the Independence of Guinea and Cape Verde $\left(\mathrm{PAIGC}^{31}\right)$ and intensified the campaign for greater popular adhesion to the objectives of the Party (Woollacott, 1983, p. 1134).

The year 1963 marked the beginning of the armed struggle by the PAIGC, which managed to achieve some important victories. In 1964, the PAIGC won an important victory by securing the territorial control of the Como Islands, despite the strong repression of the Portuguese army. From then on the PAIGC extended its

\footnotetext{
${ }^{30}$ Acronym for Portuguese Partido Africano da Independência.

${ }^{31}$ Acronym for Portuguese Partido Africano para a Independência da Guiné e Cabo Verde.
} 
territorial domain and in 1966 already controlled two thirds of the current territory of Guinea-Bissau (Woollacott, 1983, p. 1134).

In 1968 the Portuguese government appointed a new governor, António de Spínola, to the province in order to try to negotiate a transition agreement for the independence of Guinea-Bissau in a process lasting up to ten years. The main objective of this possible agreement was precisely to avoid an alarming military defeat dangerous for the Portuguese Empire, with the possibility of influencing other colonies to rebel. The real consequence of Spinola's appointment and policy was the intensification of the armed struggle and the number of deaths on both sides of the conflict (ibid, p. 1135-1137).

The Portuguese military, diplomatic and political situation in Guinea-Bissau has deteriorated rapidly since 1968. On September 24, 1973, a National People's Congress unilaterally declared Guinea-Bissau independence. Guinea-Bissau's independence was recognized by more than seventy countries until October of that year and in November the United Nations declared that they recognized the PAIGC as the legitimate representative of the people of Guinea-Bissau and considered any type of Portuguese presence in the illegal territory (ibid, p. 1377). The first reaction of the Brazilian government to the declaration of independence of Guinea-Bissau was to prove contrary to the decision. Brazil voted contrary to a UN resolution that recognized the decision of the National People's Congress. It is also worth noting that the recognition of the independence of Guinea Bissau by the Brazilian government only happened the following year (Abdenur; Souza Neto, 2014, p. 6).

Amílcar Cabral did not saw the independence of Guinea Bissau come to fruition once he was assassinated in early 1973 by a partisan. Meanwhile, his halfbrother Luís Cabral served as president of the Bissau-Guinean state until 1980 when there was a coup d'etat on November $14^{\text {th }}$ and Bernardo "Nino" Vieira, who was the prime minister and had already been the commander of the Armed Forces, took over the power, through a military junta led by him until 1984, when a new constitution was approved and he was maintained president (Rizzi, 2010, p. 23).

The year 1991 was marked by the occurrence of the first democratic election in the history of Guinea-Bissau and Nino Vieira was elected president and remained in power until 1998, when he was deposed by a military coup conducted under the leadership of General Ansumane Mané, which remained in power until 1999. The provisional government of Guinea-Bissau sent representatives to Brazil with the 
intention of discussing with Brazilian President Fernando Henrique Cardoso measures of assistance from the Brazilian government to the African state (Abdenur; Souza Neto, 2013, p. 109; Rizzi, 2010, p. 24).

The situation of constant political instability in Guinea-Bissau led the United Nations Security Council to create the United Nations Peacebuilding Support Office in Guinea-Bissau (UNOGBIS), through Resolution $1233^{32}$, with the primary role of auxiliary in promoting democratic elections. UNOGBIS was also responsible for providing the political framework and leadership for harmonizing and integrating the activities of the United Nations system in Guinea-Bissau during the transitional period leading up to general and presidential elections. However, the mandate of UNOGBIS was rather limited since the Security Council members did not saw Guinea-Bissau as a priority. It is worth noting that the extensions of the UNOGBIS mandate that took place after the 2000 and 2005 elections were held only because of pressure from the Brazilian government (Abdenur; Souza Neto, 2013, p. 109).

General Mané stepped down as president by handing over the post to PAIGC leader Malam Sanha, who called general elections in 2000, which elected Kumba Yalá as president. However, President Yalá was unable to finish his term, being ousted in 2003 by a new coup d'état, this time led by General Veríssimo Seabra. A new election took place in 2005 electing once again Nino Vieira as president. Soon after his election Nino Vieira dissolved the parliament and the Prime Minister and appointed an ally for the position (Rizzi, 2010, p. 24).

The year of 2005 was also marked by the creation of the Peacebuilding Commission (PBC), an intergovernmental subsidiary body of the UNSC with the objective of assisting states in post-conflict situations to achieve peacebuilding and development. The period of creation of the PBC coincides with the period of intensification of relations and technical cooperation for the conduction of elections between Brazil and Guinea-Bissau (Abdenur; Souza Neto, 2013, p. 109-110).

On July 11,2007 , in a letter to the Secretary General of the United Nations ${ }^{33}$, Martinho Dafa, Minister of Defense of Guinea-Bissau, requested Guinea-Bissau to

\footnotetext{
${ }^{32}$ Available in English at: <https://undocs.org/S/RES/1233(1999)>. Accessed on: 25 Oct 2018.

${ }^{33}$ Available in English at: <http://www.un.org/en/peacebuildingpeacebuilding/cscs/gb/key_docs/country_request_gb.pdf $>$. Accessed on: 25 Oct 2018 .
} 
be part of the PBC's agenda. The Brazilian government pressed for acceptance of the Bissau-Guinea-Bissau request and with the acceptance of the request, Brazil received the invitation to chair the Specific Configuration of PBC for GuineaBissau in December 2007 (ibid, p. 110). Since then, the Presidency of the Specific Configuration for Guinea-Bissau has been exercised by Brazil.

However, despite the initial efforts led by PBC and Brazilian diplomacy, instability has not been remedied. In March 2009 President Nino Vieira and General Batista Tagme Na Waie were assassinated, triggering another political crisis for the country. This situation led the UNSC to adopt a resolution dissolving UNOGBIS and establishing the United Nations Integrated Peacebuilding Office in GuineaBissau (UNIOGBIS). Despite the similar name, the mandate of the new Office has a broader scope of action and with the task of coordinating all the efforts of UN agencies operating in Guinea Bissau (Abdenur; Souza Neto, 2013, p. 110; Rizzi, 2010, p. 24). The presidential election in 2009 marked the return of the PAIGC to power after electing Malam Sanhá.

The Brazilian role in Guinea-Bissau has been intensifying since the creation of the PBC and UNIOGBIS. In addition to these mechanisms, Brazilian diplomacy has also been working through other institutional environments to promote democracy, political stability and human rights. Thus, Brazil has been participating in debates and coordinating efforts with organizations such as the European Union, the World Bank, the Community of Portuguese Speaking Countries $\left(\mathrm{CPLP}^{34}\right)$ and the International Monetary Fund, among others (Abdenur; Souza Neto, 2013, p. 111).

In early 2012, Malam Sanhá's death was announced and Raimundo Pereira assumed the presidency on an interim basis. However, a new coup attempt was made and Pereira was deposed. This attempted coup led to the suspension of a number of international funds the state had been receiving and there was a strong pressure movement from international donors. There was a transitional government and elections were scheduled for 2014, when José Mário Vaz, PAIGC candidate was elected. In September of the same year President Vaz sacked Antonio Indjai, the Armed Forces chief, which was accused by the United States of plotting to traffic cocaine and sell weapons to Colombian rebels.

\footnotetext{
${ }^{34}$ Acronym for Portuguese Comunidade dos Países de Língua Portuguesa.
} 
The beginning of the year 2015 represented a hope for both the people of Guinea-Bissau and international donors who pledged more than 1 billion dollars to help Guinea-Bissau's economy after years of political instability and lack of international credibility. However, in August a political crisis hit the country and forced President Vaz to sack the Prime Minister Domingos Simões Pereira in response to a series of disputes between them. In November 2016 Umaro Sissoco Embaló becomes the fifth prime minister in little over a year amid a power struggle between President Vaz and its opponents in the ruling PAIGC. Embaló was dismissed from office in January 2018, being succeeded by Augusto Artur António Silva who remained in office only until the month of April. Since then the position is occupied Aristides Gomes.

\subsection{THE BRAZILIAN EXPERIENCE IN GUINEA-BISSAU}

Brazil's participation in the Guinea-Bissau's statebuilding process is relevant for both countries. For the Brazilian diplomacy and government, the process is seen as an opportunity to showcase its peacebuilding approach to other countries. For Guinea-Bissau, the process is extremely relevant since many of the former partners left the country because of the great political instability, especially after the coup d'État attempt in 2012 (Abdenur; Souza Neto, 2013, p. 113).

In addition to these facts, it must be recognized that the Brazilian performance in Africa is seen as a key position for the strategy of international insertion and affirmation of the country itself as an emerging power. It is seen as necessary by any great power to act in normative challenges and debates of international security (Stolte, 2015, p. 147). In this sense, the Brazilian ability or inability to carry out a statebuilding process on the continent can be interpreted by the international community as a kind of "test" and opportunity at the same time.

It should also be noted that since the time of the League of Nations Brazil has the desire to occupy a permanent seat on the Security Council. Because of the number of member states of the United Nations, the African continent is seen as extremely relevant to the realization of pressure and adoption of any measure and change in the United Nations. As a result, Brazil's actions on the African continent intensified over time, as discussions on a possible reform of the UNSC took place during the post-Cold War period. These Brazilian actions in Africa, including the 
Brazilian role in Guinea-Bissau, can therefore be read as an attempt to convince African countries of the benefits that a Brazilian seat in the UNSC would bring to their societies (Stolte, 2015, p. 143-144).

The Brazilian presence in Guinea-Bissau has some constraints and some similarities with the Brazilian presence in Haiti. First, it is important to note that while in Haiti, as already presented in the previous chapter, the Brazilian presence was deeply marked by participation in a United Nations peacekeeping mission in Guinea-Bissau this presence has taken place primarily through the peacebuilding Commission. In this sense, while in Haiti there is the presence of a strong military component, in Guinea-Bissau the Brazilian performance occurs without this apparatus. However, in both countries the presence of Brazilian bilateral cooperation beyond the institutional instruments of the United Nations is remarkable and occurred even before the Brazilian engagement through the UN (Abdenur, 2017, p. 465).

Another point that must be noted is that Guinea-Bissau presents a significantly different set of challenges when compared with Haiti. In Haiti violence issues has been concentrated in dense and poor urban areas. On the other hand, in Guinea-Bissau violence has a more political character and has been mostly restricted to narrow ruling elites and to periodic interruptions of the constitutional order. It should also be noted that Guinea-Bissau had not experienced ethnic infighting that many other African countries have experienced. However, social cleavages among key ethnicities (the country officially recognizes 32 groups) are capable of generating and reinforcing tensions, including between the country's military and political circles (ibid, p. 466).

As presented in the previous session, Brazil recognized Guinea-Bissau as an independent country in 1974 and supported its entry into the United Nations as a member-state. However, Adriana Abdenur (2017) shows that until the 1990s the cooperation between the two countries had no substantial projects and results. This was due to the fact that Brazil was experiencing a military dictatorship until the mid-1980s, and Guinea-Bissau faced a series of coups d'état. Thus, although a technical cooperation agreement was signed in 1978 between the two countries, there were few high-level visits in those almost 15 years. It was only after the Brazilian redemocratization in the 1990s that the country began to advocate more strongly on the international scenario in favor of Guinea-Bissau. It is worth noting 
that this relationship became more important and strategic to Brazil after CPLP's foundation in 1996. At first CPLP's main focuses were in cultural initiatives in order to promote the standardization of the orthography of the language. However, the organization had its agenda expanded and began to contemplate topics such as the promotion of development, security and also human rights. These themes made CPLP increasingly important for Brazilian foreign policy since Brazilian leaders saw it as an opportunity to enhance the Brazilian influence in Africa (p. 465).

It is important to note that the political instability in Guinea-Bissau dates back to the 1980 s as already presented briefly on the previous pages. However, around 2006 the country drew the attention of the international community, as there were strong evidences that drug traffickers were using Guinea-Bissau as a hub for transatlantic cocaine trafficking. It was precisely within this context that the country came to be considered failed and/or fragile by think tanks that promote ranks of state fragility and as a potential threat to regional and, in the limit, international security. In this sense, Brazilian diplomats and political leaders, as in Haiti, repeatedly drew the attention of the international community to the need to adopt socio-economic measures along with security-focused measures. As in Haiti, security-focused measures have been the primary focus of the international community and great powers' involvement with Guinea-Bissau (ibid, p. 466).

However, it is important to note that Brazil has been facing some limitations and difficulties within the United Nations peacebuilding architecture, especially related with resources destination. Resources were and still are more commonly mobilized for SSR and other security issues than for socioeconomic development efforts. It is worth noting that in the 2000s several donors faced the so-called "donor fatigue" and had either scaled back their initiatives or completely withdrawn from Guinea-Bissau. In addition, a condition of lack of coordination between the PBC and the peacebuilding Fund was and continues to be a further complicating factor in the Brazilian role in Guinea Bissau, causing some situations incompatibility of priorities. It must also be noted that during the 2000s Guinea-Bissau was not the only African country to receive attention from the international community, having "competed" for attention with conflicts in the Central African Republic, increased tensions and violence in the eastern part of Congo and instability in Mali. (ibid, p. 466-467). 
As already presented, the Brazilian statebuilding strategy has South-South Cooperation as a major component. In the case of Guinea-Bissau, the cooperation reflected and continues to reflect the multiple scope of the Brazilian activity, allowing the formations of state capacity to be deployed in several areas and not only the traditionally privileged areas. Thus, some of Brazil's areas of activity in Guinea-Bissau are, according to Jorge Kadri (2014), Brazilian ambassador to Guinea-Bissau between 2008 and 2012:

"Capacity building, leadership, almost state renewal, state creation, I think minimum conditions for the country can be an effective state, with qualifications to govern. Because our cooperation has been in multiple sectors. It was from the Armed Forces, security, health, education, cultural, human rights. In short, a very wide range: technical training, combating AIDS, which is a very beautiful project" (p. 21. Author's translation).

Another important point that is present in Brazilian action is the issue of non-imposition of measures on the local country and its constant presence and importance in the process of construction of state structures. Therefore, Brazil seeks the effective promotion of local ownership, and this issue is present in the cooperation projects developed by Brazil in Guinea-Bissau, unlike other countries, such as China that:

"builds football stadium, parliament, government house, some roads and, as a counterpart, receives fishing, fishing resources, wood and etc. It is a more direct interest. It is not a cooperation as Brazil does. Brazil has twenty-three cooperation projects and this cooperation is done in a different way, a dialogue: we go, talk, listen and only do what the stakeholder is convinced is good for them. So it is a very dialogue to listen carefully, it is not an imposed thing and it does not aim an immediate interest. It will aim in the long run for some kind of interest: sympathy for the country to have helped. If you develop several successful projects, the country comes interested in doing business eventually" (Kadri, 2014, p. 22. Author's translation).

The Brazilian government through the Brazilian Cooperation Agency, according to data from the agency itself, has a total of 89 Cooperation projects with Guinea-Bissau between completed and in progress. It is worth mentioning that these projects can be of South-South cooperation or trilateral cooperation. It should also be noted that the area with more projects is precisely the area of education with 25 projects, where most of these projects are aimed at the professional training of public officials. It is also worth mentioning several projects in the health area that focus on HIV treatment and the reduction of infant mortality and projects for the implementation and modernization of techniques in agriculture and in the African 
country, with the aim of stimulating the productivity of the sector and the country's economy.

It should be noted, however, that, ironically, the largest South-South cooperation project between Brazil and Guinea-Bissau aimed precisely at the construction and establishment of a training center for local police and security forces. This project is part of a larger effort whose main purpose is to assist in the professionalization of Guinea Bissau's police forces, and to help separate their functions from those carried out by the country's military, which still have a considerable political force (Abdenur, 2017, p. 467). This Brazilian cooperation project is part of a series of SSR projects and measures promoted by international organizations and states in the territory of Guinea-Bissau.

The set of SSR measures promoted in Guinea-Bissau is based on the attempt to create the so-called "perfect" institutions. This type of institutions is possibly inappropriate for the country as it is usually considered as a fragile state by the international community. Thus, there is a high probability of failure in the process of consolidating these institutions as envisioned by sponsors, donors, and partners in the statebuilding process. At the limit, this type of failure is capable of creating frustrations and, consequently, of constraining the creation of formulas of state organization and conflict resolution (Carvalho, 2010, p. 60).

SSR actions in Guinea-Bissau therefore seek essentially to reduce the number of personnel in the areas of defense and security, as well as modernize the Armed Forces. These measures end up being received with great distrust by the Armed Forces, who fear not only the reduction of the number of troops and, consequently, the creation of a significant number of "losers" of the reform, but also the impoverishment and loss of money on the part of the military (ibid, p. 62). In this way, it can be said that the Brazilian actions for the security area in the statebuilding process also contribute to the consolidation of these tensions involving the military sector and the various reforms in the security sector.

One of the main local critiques of SSR processes promoted and sponsored by the international community (including the ones promoted by Brazil) by international political analysts is precisely the lack of local ownership. Many outside observers argue that these SSR actions represented a simulacrum of a military intervention imposed by the United Nations and other international actors. However much this criticism is exaggerated, it has a certain relevance since, 
according to this argument, the complexity of security reforms has been underestimated by the international community. These international actors were not familiar with local realities and cleavages, thus not anticipating the degree of resistance that reforms could bring about in groups close to the military and political power of Guinea-Bissau (ibid, p. 12-13).

Cristoph Kohl (2014) argues that the word reform itself represents a tension for the SSR in Guinea-Bissau. This fact occurs because few people in the country, be they civil society or the security sector itself, are familiar with the theme and the idea of local ownership. This type of knowledge ends up being limited to international experts and agents directly involved in the process. In this context, SSR was commonly first interpreted by military and police as a forced retirement measure for older professionals since the term reforma in Portuguese can mean both "reform" and "retirement", generating even more tension about the concept and about the safety agenda. The issue of security is an issue that, despite being much debated in conjunction with the themes of crime and corruption, which are considered central to the country's development, its reform is something that is disputed between the professionals of the area and the local population (p. 14).

Another common criticism of the statebuilding and SSR process in GuineaBissau is the assumption, implicitly or explicitly, by international actors of a view based on the theory of modernization and cognitivism. In this scope, it is believed that the development of countries around the globe occurs in a linear way having the so-called global north as an example to be emulated. Add to this the idea that knowledge can simply be transported from a "sender" to a "recipient". In this way, the various complexities that the learning process (both institutional and individual) has and the advantages of individual processing are neglected (Kohl, 2014, p. 19).

Several representatives of international organizations and developed states argue that Guinea-Bissau needs "modern" structures that can be transmitted by the global north as an example to be emulated. In that sense, several representatives of the international community confessed that this conviction was clearly manifested in the legal and legislative sphere, since Portuguese experts copied passages from Portuguese legislation for the military and police sector and applied them in the legal framework of Guinea-Bissau. The Portuguese experts did so by claiming that because of a supposed lack of competence on the part of Guinea-Bissau and its 
political, legal and legislative representatives such action was necessary (ibid, p. 19).

So, it is observed that many of the statebuilding actions, especially those of SSR, promoted in Guinea Bissau by international agents, have as a characteristic the assumption that practices commonly adopted in the global north should be taken as examples to be followed. One of these practices was, according to Cristoph Kohl (2014), the creation of a National Guard sponsored by Spanish and Portuguese experts in 2010 as these countries have similar proto-military structures exercising police power. Like the police, the National Guard is also responsible for public order and reports to the Interior Ministry. However, the National Guard also reports, at least de jure, to the Ministry of Defense forming a double structure in its chain of command (p. 20).

Since the creation of the National Guard a number of criticisms have been made in the sense that this new organization could disrupt the fragile structures and balance of domestic power. The "imported" National Guard model did in fact disrupt the country's political environment since a significant portion of the military saw the National Guard as an opposition and at the same time a threat to the privileges and roles they played. In this context, the creation of the National Guard created and deepened conflicts between different security entities, each of which aimed at maintaining its area of activity and its own power in the country's political game. There were several episodes of violence between the country's defense and security forces that were seen as an attempt to maintain the inherent power of each (Carvalho, 2010, p. 62; Kohl, 2014, p. 20).

In this context, as previously stated, the Brazilian government and diplomacy argue that the country's actions in Guinea Bissau are different from those practiced by states and international organizations representative of the so-called global north. In fact, it is perceived that Brazil has a series of cooperation projects in several areas beyond the security area in Guinea-Bissau. However, as also presented previously, it is noted that the largest Brazilian cooperation project with Guinea-Bissau is a project related with the security and defense area.

Cristoph Kohl (2014) presents another Brazilian action of SSR attempt that has an effect below the planned, but not necessarily negative effect: The courses promoted by the Brazilian federal police for officers of the law of Guinea-Bissau. Although education and training courses are considered by specialists as effective 
measures to promote personnel training and behavioral change for those who perform them, this result was not perceived in a long-term course offered by the Brazilian federal police to train police officers Guinea-Bissau to act in border control, frustrating the course instructor since it was believed that participants would assimilate the foundations of professional police, democracy, human rights and military work. In addition, it was expected that by applying the content and philosophy taught in the course participants would cease any corrupt practices and more (p. 20).

However, there are reports that several police officers and security officers from Guinea-Bissau would not be applying the theoretical and practical content of the course in the field. Police officers who participated in this training offered by the Brazilian federal police did not have a change observed in their behavior in the work environment, being a source of frustration for the Brazilian instructors since this cooperation project would not be effective. The Brazilian instructors themselves point out the lack of continuity and the isolated nature of the course as fundamental factors for the failure of this South-South cooperation project. However, it is also questioned whether longer-term courses would be able to change the behavior of their participants since even with the behavioral internalization by the police would persist structural fundamental deficits in both the police service and the public administration of Guinea-Bissau in one aspect more broadly. Finally, a significant portion of the country's police officers, especially the younger ones, are attracted to symbols and material goods, mimicking images of members of "western" security forces and police officers.

\subsection{CONCLUSIONS}

The Brazilian statebuilding actions around the globe for states considered to be "failed" and "fragile" are driven by the notion that each case is a specific case that needs specific solutions, without importing Western models of development, and incorporating the specificities locations. Silvia Roque (2009) argues that in Guinea- Bissau the Brazilian strategy differs from the strategies adopted by Western powers for not prioritizing their actions only in the areas of defense, national security and in combating drug trafficking. It is argued that the Brazilian strategy does not focus on creating conditions for the police and armed forces, but rather the 
creation of sustainable structural economic conditions and the promotion of social development as mechanisms to promote lasting peace and an end to political tensions and disputes power in the country (p. 16).

Brazilian diplomacy has always presented and emphasized its position of giving voice and importance to local actors in the processes of statebuilding. In the case of Guinea- Bissau, it has been sought over the years in which Brazil is involved in working together with Angola in joint military operations with Guinea-Bissau in order to promote exercises and technical-military cooperation between countries (Abdenur; Souza Neto, 2013, p. 111).

However, at the beginning of this chapter, and especially in the previous section, it was possible to observe that although Brazilian actions in Guinea-Bissau have a broader and more diversified scope than the actions promoted by other countries, the largest cooperation project sponsored by Brazil in the area of security. In addition, it was realized that precisely the lack of social conditions and structural work projects carried out in the area of security by Brazil. Thus, it can be said that the country still faces serious structural problems, much as a result of the various ruptures and constitutional crises involving coups d'état, internal power struggles between politicians and the military.

Within the field of study of international norms, it is possible to classify the Brazilian action in Guinea-Bissau as a contestation in relation to the application of the liberal peace norm cluster since the problems identified by the country in Guinea-Bissau are the same as those presented by Table 1 in Chapter 2, although Brazil does not use the state fragility nomenclature. In addition, the values defended by Brazil in its action both through the United Nations and through its operation through various cooperation mechanisms are essentially the same as the norm cluster in question. However, there is a difference in the methods of applying these values when compared to the mechanisms traditionally employed by countries of the so-called global north and by international organizations. Finally, it can be said that Brazil's action in Guinea-Bissau represents an important point of experimentation and consolidation for the so-called Brazilian way of peacebuilding since the country has a major role and leadership in the specific configuration of the peacebuilding Commission. 


\section{CONCLUSIONS}

Throughout the development of the present work it was possible to observe the importance that the debates and studies on norms have for the discipline of International Relations. In addition, it has also been observed that norms have a significant impact on international practices, being part of the principles, rules and values that guide them. It was also noted that a number of possible processes exist around the emergency and after consolidation of a particular standard. This dissertation sought to analyze the attitude of normative contestation presented by Brazil through its actions in Haiti and Guinea-Bissau both through United Nations platforms and through bilateral actions and their impacts on the norms and practices of peace operations and statebuilding.

Therefore, the present dissertation was divided into seven chapters that made it possible to analyze this question from both a theoretical and a practical point of view. This division was made in such a way as to make possible the research accomplished during the accomplishment of the master's degree, seeking to present in a linear way the theoretical framework used, the basic contents for the analysis to be carried out and, finally, the case studies. Thus, the first chapter presented in general the subject to be studied and the methodology used throughout the development and the hypotheses of the dissertation.

The second chapter of the dissertation proposed to present the academic debates of the discipline of International Relations involving norms. In this sense, for the didactic purposes, a division of the studies of norms in the disciplines into four different norms was presented, although only three waves are commonly recognized. For the separation of the studies in four waves, the definition of the standard used by the studies was taken into account. The commonly adopted definition of a standard is one that understands it as a shared set of behavior patterns and identities of a particular social group that guides practices and expectations about the actors' attitudes in a given environment and social context (Jepperson; Katzenstein; Wendt, 1996, p. 54; Klotz, 1995, p. 14; Kratochwil, 1989, p. 24; Onuf, 1989, p. 84; Wendt, 1999, p. 267). 
However, it has been realized that there is a literature within the discipline that deals with the concept of norms in another way in which they are in a constant process of contestation and, therefore, there is not a sharing of sets of values, identities and behaviors throughout a social group. Thus, the norms would be the result of a constitutionalist process in which the inputs of different agents generate different outputs that vary from actor to actor. This ontological difference between the first three waves of norm studies in the discipline and the so-called fourth wave was the decisive factor for its framing as a different wave.

Then a discussion was made of philosophical liberalism and its relation to the so-called liberal peace. In the first moment the influence that the philosopher Immanuel Kant possessed in the basic precepts of modern international political liberalism was presented. Secondly, it has been shown that liberal peace is a political construction and project that can be divided into three temporal phases that, despite having divergent points and characteristics, have the same central ideas, but with different applications. Finally, in this chapter, we presented a framework in which the conception of liberal peace that we have today is not treated as a single norm, but rather a norm cluster in which there are a series of values, problems and beliefs that act together and end up influencing a series of actions by international agents, among which we can highlight the peace operations and the actions of statebuilding.

In the fourth chapter the bases of the Brazilian political and diplomatic thought were presented with respect to the norms of international intervention. It was sought to show that although the country has always shown itself in favor of nonintervention, this discourse underwent a significant change with its entry into MINUSTAH and the adoption of the principle of non-indifference, being an important inflection point in the Brazilian foreign policy. In addition, it was argued that the country comes, especially after the end of the military regime that prevailed in the country until the mid-1980s, to engage in international security debates and practices, contributing troops to peace operations, but also engaging in normative discussions such as the discussion about the Responsibility to Protect and the proposition of the alternative concept of Responsibility while Protecting.

Throughout the fifth chapter it was sought to present a brief history and political and social context in which Haiti was immediately before the United Nations decision to authorize the creation of MINUSTAH and the Brazilian 
decision to assume its responsibilities to the mission. In addition, through the exposure of the Brazilian action to include certain clauses and objectives within the scope of the mission, the objective was to show the country's effort to present a proposal different from the traditional ones for peacekeeping actions. Thus, the chapter also presented the civil, political and military actions performed by the Brazilians throughout the term of the mission. It is important to note that that although MINUSTAH has been considered a "success" by a large part of the Brazilian military involved in it and by the United Nations personnel, this "success" does not even come close to being a consensus within Brazilian and international public and academic opinion, and there have been severe criticisms of the Brazilian performance in Haiti.

Through the analysis of these actions it was noticed that the Brazilian action combined both aspects considered as traditional in the peace missions, especially those developed after the end of the Cold War, having the robustness of the use of force as one of its pillars, as well as cooperation South cooperation, the promotion of humanitarian aid and the use of unconventional means to solve local violence by focusing not only on the use of force. Among the actions considered as unconventional used by the Brazilians during their stay in Haiti may be highlighted the achievement of the so-called "Match of Peace" between the Brazilian soccer team and the Haitian team, the performance of the Brazilian Army's engineering battalion for the construction of roads, the promotion of vaccination campaigns and the work of non-governmental organizations partners of the Brazilian Government and MINUSTAH in the treatment of water.

However, even though actions considered to be unconventional really made the so-called "Brazilian way of peacebuilding" different from the peacebuilding tradition traditionally pursued by the United Nations, they had convergent goals and values and saw the same problems being solved. Thus, as presented in the theoretical field by Nicole Deitelhoff and Lisbeth Zimmermann (2013) there was a dispute regarding the application of the norm cluster of liberal peace. In addition, the characterization of MINUSTAH as a stabilization mission, its relative success and the implementation of missions with the same scope in other locations around the globe after MINUSTAH can be read as an emergency movement of a new type of Mission of Peace, which became part of the norm cluster of liberal peace. 
Framing stabilization as an integral part of the liberal peace norm cluster may at first seem inappropriate, since the very idea of stabilization is not intended to create new state structures but merely to stabilize the "terrain". However, it was noted throughout the chapter that, although actions have this goal, they aim to combat all problems identified in the cluster and share the same values. The fact that in stabilization practices are not necessarily committed with the reconstruction of a state structure, but rather with the goal of promoting minimum conditions of stability does not make it an attitude outside the cluster. This fact demonstrates only the lesser propensity of the agent or set of agents involved in the process of deducing more financial and human resources in the actions, focusing only on a harm reduction strategy.

Finally, the other case study presented in the next chapter was the Brazilian action in Guinea-Bissau through the presidency of the United Nations peacebuilding Commission's Specific Configuration for the country and bilateral and multilateral actions. Through these actions it was seen that the Brazilian action has a focus that goes beyond the question of reforming the security sector, which is a common and predominant pattern in the actions of statebuilding. It was also noted that a number of other states and organizations also operate in the SSR in GuineaBissau and that several problems are observed in the implementation of these measures. However, even though Brazilian actions have a focus that "goes beyond security issues", the importance of SSR is predominant. In this way, it was observed again that the Brazilian action has characteristics of contestation in relation to the application of the norm cluster of Peace Liberal since there is not necessarily a challenge regarding the problems and objectives of this norm cluster, but only sought to implement it, in a different way incorporating other practices.

Thus, observing the two case studies proposed, it is possible to say that the results of the Brazilian action end, finally, strengthening the norm cluster of liberal peace. This fact occurs because, following the line of thinking that treats the norms from the constitutional point of view, there is a dispute over the meaning-in-use of this cluster in which Brazil seeks to insert certain specific aspects without necessarily exclusion of others. There is, therefore, no divergence, but a complementarity.

In this sense, throughout the dissertation it was possible to observe that Brazilian actions in Guinea-Bissau and Haiti can be perfectly framed as 
international practices, as defined by Emanuel Adler and Vincent Pouliot (2011). This fact occurs since these actions are in compliance with the five aspects listed by the authors. Firstly, both Brazilian performance in Haiti and Guinea-Bissau are performances that are made up of a multitude of actions and processes that unfold in real time. Secondly, these performances have a pattern. peace operations, for example, have a set of rules of engagement and action standards for each circumstance, and statebuilding and cooperation projects through the United Nations must comply with a number of provisions. Third, there is a high degree of knowledge and competence for the planning and execution of both a military action and a cooperation project. Fourth, these performances are extremely influenced by knowledge acquired previously in other situations. Finally, in both cases there is both the ideational aspect - the intention to provide better security conditions for the local populations along with a more balanced social environment - as well as the material component.

Thus, it was through the analysis of these practices that the present work reached the aforementioned conclusions. In this way, the hypotheses presented in the introduction can be considered as tested and approved. However, this fact does not end the possibilities of research within this field. This dissertation did not objectify this fact and neither does the author think he is capable of doing so. Therefore, some points that were not treated during the execution of the present work but which the author deems to be relevant for the development of the research agenda, both in relation to the theme involving the Brazilian insertion in the intervention norms debates and in the theoretical agenda involving norms in the discipline, will be presented with the intention of fostering them: How does (the United States, Canada, the European Union, Norway, and Russia, for example) interpret the Brazilian normative work described in the dissertation? To what extent do these Brazilian actions assist the country in its historic appeal for a permanent seat on the Security Council? Are the practices of contestation in relation to the application of the norm the most effective mechanism for the insertion of emerging powers in the spaces of discussion of these norms? 


\section{BIBLIOGRAPHY}

ABADIA, Danúbia. A rejeição revolucionária do colonialismo: Amílcar Cabral e a luta de libertação na Guiné-Bissau e em Cabo-Verde. Revista Espaço Acadêmico, n. 183,2016 , p. $113-125$.

ABBOTT, Kenneth. et al. The Concept of Legalization. International Organization, v. 54, n. 3, 2000, p. $401-419$.

ABDENUR, Adriana; CALL, Charles. A "Brazilian way"? Brazil's approach to peacebuilding. Geoeconomics and Global Issues, n. 5, 2017, p. 1 - 26.

ABDENUR, Adriana; SOUZA NETO, Danilo Marcondes de. Rising powers and the security-development nexus: Brazil's engagement with Guinea-Bissau.Journal of Peacebuilding \& Development, v. 9, n. 2, 2014, p. 1 - 16.

ABDENUR, Adriana; SOUZA NETO, Danilo Marcondes de. Rising powers and the security-development nexus: Brazil's engagement with Guinea-Bissau. Journal of Peacebuilding \& Development, v. 9, n. 2, 2014, p. 1 - 16.

ABDENUR, Adriana; SOUZA NETO, Danilo Marcondes de. South-South cooperation and democracy in Africa: Brazil's role in Guinea-Bissau. African Review, v. 5, n. 2, 2013, p. $104-117$.

ABDENUR, Adriana. What Can South-South Development Cooperation Do for International Peace? Brazil's Role in Haiti and Guinea-Bissau. International Negotiation, v. 22, 2017, p. $451-472$.

ACHARYA, Amitav. How Ideas Spread: Whose Norms Matter? Norm Localization and Institutional Change in Asian Regionalism. International Organization, v. 58, n. 2, 2004, p. $239-275$.

ACHARYA, Amitav. Norm Subsidiarity and Regional Orders: Sovereignty, Regionalism, and Rule-Making in the Third World. International Studies Quarterly, v. 55, 2011, p. 95 - 123.

ACHARYA, Amitav. The R2P and Norm Diffusion: Towards a Framework of Norm Circulation. Global Responsibility to Protect, v. 5, 2013, p. 466 - 479.

ACHARYA, Amitav. Whose Ideas Matter?: Agency and Power in Asian Regionalism. Ithaca: Cornell University Press, 2009. 
ADLER, Emanuel; Pouliot, Vincent. International Practices. International Theory, v. 3, n. 1, 2011, p. $1-36$.

AGÊNCIA ESTADO. Haitianos fazem festa para a seleção. Estadão, São Paulo, 18 ago. 2004.

ALLES, Leonardo; EKSTRÖM, Karin. Brazilian Foreign Policy under Lula: From non-intervention to non-indifference. Political Perspectives, v. 6, n. 2, 2012, p. 9 29.

ALSINA JÚNIOR, João Paulo. Grand Strategy and Peace Operations: the Brazilian Case. Revista Brasileira de Política Internacional, v. 60, n. 2, 2017, p. 1 - 22.

AXELROD, Robert; KEOHANE, Robert. Achieving Cooperation under Anarchy: Strategies and Institutions. World Politics, v. 38, n. 1, 1985, p. 226 - 254.

BARAKAT, Sultan; DEELY, Séan; SYCK; Steven. The Evolution of Stabilization Concepts and Praxis. IN: MUGGAH, Robert. Stabilization Operations, Security and Development. London: Routledge, 2013. p. 15 - 34

BARNETT, Michael. Building a Republican Peace: Stabilizing states after war. International Security, v. 30, n. 4, 2006, p. $87-112$.

BENFORD, Robert; SNOW, David. Framing Processes And Social Movements: An Overview and Assessment. Annual Review of Sociology, v. 26, 2000, p. 611 639.

BJÖRKDAHL, Annika. Norms in International Relations: Some Conceptual and Methodological Reflections. Cambridge Review of International Affairs, v. 15, $\mathrm{n}$. 1, 2002, p. $9-23$.

BLANCO, Ramon. The Brazilian Engagement with Peace Operations: a Critical Analysis. Revista Brasileira de Política Internacional, v. 60, n. 2, 2017, p. 1 - 20.

BLOOMFIELD, Alan. Norm antipreneurs and theorising resistance to normative change. Review of International Studies, v. 42, n. 2, 2016, p. 310 - 333.

BRACEY, Djuan. O Brasil e as Operações de Manutenção da Paz da ONU: Os Casos do Timor Leste e Haiti. Contexto Internacional, v. 33, n. 2, 2011, p. 315 331.

BROCKMEIER, Sarah; STUENKEL, Oliver; TOURINHO, Marcos. "Responsibility while Protecting": Reforming R2P implementation. Global Society, v. 30, n. 1, 2016, p. $134-150$.

BUEGER, Christian; GADINGER, Frank. International practice theory: New perspectives. Basingstoke: Palgrave Macmillan, 2014. 
BUEGER, Christian; GADINGER, Frank. The play of international practices: Minimalism pragmatismo and critical theory. International Studies Quarterly, v. 59, n. 3, 2015, p. $449-460$.

CARVALHO, Ana. Intervenções Externas no Sector de Segurança na GuinéBissau. Lusíada. Política Internacional e Segurança, n. 4, 2010, p. 49 - 70.

CEZNE, Eric; HAMANN, Eduarda. Brazilian Peacekeeping: Challenges and Potentials in Turbulent Landscapes at Home and Internationally. PRIO Policy Brief, n. 22, 2016.

CHANDLER, David. Empire in Denial: The politics of state-building. London: Pluto Press, 2006.

CHAPPUIS, Fairlie; HÄNGGI, Heiner. Statebuilding Trough Security Sector Reform. IN: CHANDLER, David; SISK, Timothy (Eds.). The Routledge Handbook of International Statebuilding. London: Routledge, 2013. p. 168 - 184.

CHECKEL, Jeffrey. Institutions, and National Identity in Contemporary Europe. International Studies Quarterly, v. 43, n. 1, 1999, p. 83 - 114.

COLOMBO, Cristóvão. Diários da descoberta da América: As quatro viagens e o testamento. Porto Alegre: L\&PM Editores, 2005.

CONING, Cedric de; FEARNLEY, Lillah; HARVEY, Joanna. (Eds). United Nations Department of Peacekeeping Operations and Department of Field Support Civil Affairs Handbook. New York: United Nations, 2012.

DE ROSA, Felippe; KENKEL, Kai. Localization and Subsidiarity in Brazil's Engagement with the Responsibility to Protect. Global Responsibility to Protect, v. 7, 2015, p. $325-349$.

DEITELHOFF, Nicole; ZIMMERMANN, Lisbeth. Things We Lost in the Fire: How Different Types of Contestation Affect the Validity of International Norms. PRIF Working Papers, n. 18, 2013, p. $1-17$.

DOYLE, Michael. Liberal Peace: Selected essays. London: Routledge, 2012.

DUARTE, Evandro Charles Piza; QUEIROZ, Marcos Vinícius Lustosa. A Revolução Haitiana e o Atlântico Negro: o Constitucionalismo em face do Lado Oculto da Modernidade. Direito, Estado e Sociedade, n. 49, 2016, p. 10 - 42.

DUFFIELD, Mark. Development, Security and Unending War: Governing the world of peoples. Oxford: Polity, 2007.

ESCOTO, Roberto. Construção do Estado e Democratização do Haiti: Uma análise das intervenções da ONU sob o enfoque da segurança humana (1993-1996 e 20042008). 2009. Dissertação (Mestrado em Relações Internacionais) - Instituto de Relações Internacionais, Universidade de Brasília, Brasília. 
FINNEMORE, Martha; SIKKINK, Kathryn. International Norm Dynamics and Political Change. International Organization, v. 52, n. 4, 1998, p. 887 - 917.

FINNEMORE, Martha. International organizations as teachers of norms: the United Nations Educational, Scientific, and Cultural Organization and science policy. International Organization, v. 47, n. 4, 1993, p. 565 - 597.

FINNEMORE, Martha. Norms, Culture and World Politics: Insights from Sociology's Institutionalism. International Organization, v. 50, n. 2, 1996, p. 325347.

FONSECA, Jamily Marciano. O Vodu no Bicentenário da Independência Haitiana. Revista Ameríndia, v. 6, n. 1, 2011, p. 55 - 60.

FONTOURA; Paulo; UZIEL, Eduardo. A MINUSTAH, o Brasil e o Conselho de Segurança das Nações Unidas. In: HAMANN, Eduarda; RAMIRES, Carlos. (Orgs). A participação do Brasil na MINUSTAH (2004-2017): percepções, lições e práticas relevantes para futuras missões. Rio de Janeiro: Instituto Igarapé, 2017, p. $9-15$.

FRITZ, Verena; MENOCAL, Aline. Understanding State-Building from a Political Economy Perspective: An Analytical and Conceptual Paper on Processes, Embedded Tensions and Lessons for International Engagement. Overseas Development Institute, 2007.

GRIMM, Sonja; LEMAY-Hébert; NAY, Olivier. "Fragile States": Introducing a political concept. Third World Quarterly, v. 35, n. 2, 2014, p. 197 - 209.

GROß, Lisa; THOLENS, Simone. Diffusion, contestation and localisation in postwar states: 20 years of Western Balkans reconstruction. Journal of International Relations and Development, v. 15, 2015, p. 249 - 264.

HANSEN, Lene. Security as Practice: Discourse Analysis and the Bosnian War. London: Routledge, 2006.

HERMANN, Breno. Soberania, não intervenção e não indiferença: reflexões sobre o discurso diplomático brasileiro. Brasília: Fundação Alexandre de Gusmão, 2011.

HERZ, Mônica; HOFFMAN, Andrea. Organizações Internacionais: História e práticas. Rio de Janeiro: Elsevier, 2004.

HIRST, Mônica. O Brasil emergente e os desafios da governança global: A paz liberal em questão. Revista Tempo do Mundo, v. 1, n. 1, 2015, p. 33 - 64.

HOPF, Ted. The logic of habit in international relations. European Journal of International Relations, v. 16, n. 4, 2010, p. $539-561$.

JEPPERSON, Ronald; KATZENSTEIN, Peter; WENDT, Alexander. Norms, Identity, and Culture in National Security. In: KATZENSTEIN, Peter. (Ed). The 
Culture of National Security: Norms and identity in world politics. New York: Columbia University Press, 1996, p. 33 - 75.

JOHNSON, Alastair. Learning Versus Adaptation: Explaining Change in Chinese Arms Control Policy in the 1980s and 1990s. The China Journal, n. 35, 1996, p. 27-61.

KADRI, Jorge. Jorge Kadri: depoimento [dez. 2014]. São Paulo, CPDOC, 2014. Entrevista concedida a Oliver Stuenkel e Marcos Tourinho para o Projeto O Brasil em crises internacionais.

KANT, Immanuel. A Paz Perpétua: Um projecto filosófico. Covilhã: LusoSofia, 2008 .

KAPLAN, Seth. Identifying Truly Fragile States. The Washington Quarterly, v. 37, n. 1,2014 , p. $49-63$.

KATZENSTEIN, Peter. Introduction: Alternative Perspectives on National Security. In: KATZENSTEIN, Peter. (Ed). The Culture of National Security: Norms and identity in world politics. New York: Columbia University Press, 1996, p. $1-32$.

KECK, Margaret; SIKKINK, Kathryn. Activists beyond Borders: Advocacy networks in international politics. Ithaca: Cornell University Press, 1998.

KENKEL, Kai; MARTINS, Marcelle. Emerging Powers and the Notion of International Responsibility: moral duty or shifting goalpost?. Brazilian Political Science Review, v. 10, n. 1, 2016, p. 1 - 27.

KENKEL, Kai. Five generations of peace operations: from the "thin blue line" to "painting a country blue". Revista Brasileira de Política Internacional, v. 56, n. 1, 2013, p. $122-144$.

KEOHANE, Robert. After Hegemony: Cooperation and Discord in the World Political Economy. Princeton: Princeton University Press, 1984.

KLOTZ, Audie. Norms in International Relations: The struggle against apartheid. Ithaca: Cornell University Press, 1995.

KOHL, Cristoph. The Reform of Guinea- Bissau's Security Sector: Between demand and practice. Frankfurt: Peace Research Institute Frankfurt, 2014.

KOSTIC, Roland; KRAMPE, Florian; SWAIN, Ashok. Liberal State-building and the Environmental Security: The international community between trade-off and carelessness. In: AMER, Ramses; ÖJENDAL, Joakim; SWAIN, Ashok. (Eds). The Security-Development Nexus: Peace, conflict and development. London: Anthem Press, 2012, p. $41-64$. 
KRASNER, Stephen. Structural Causes and Regime Consequences: Regimes as Intervening Variables. International Organization, v. 36, n. 2, 1982, p. 185 - 205.

KRATOCHWIL, Friedrich. Rules, Norms, and Decisions: On the conditions of practical and legal reasoning in international relations and domestic affairs. Cambridge: Cambridge University Press, 1989.

LIMA, Maria Regina Soares de. Autonomia, não-indiferença e pragmatismo: vetores conceituais da política exterior. Revista Brasileira de Comércio Exterior, v. 19 , n. 83, 2005, p. $16-20$.

LOBBAN JR.; Richard; MENDY, Peter Karibe. Historical Dictionary of the Republic of Guinea-Bissau. London: The Scarecrow Press, 2013.

MAC GINTY, Roger. Against Stabilization. Stability: International Journal of Security \& Development, v. 1, n. 1, 2012, p. $20-30$.

MAC GINTY, Roger. No War, No Peace: The rejuvenation of stalled peace processes and peace accords. New York: Palgrave Macmillan, 2006.

MARCH, James; OLSEN, Johan. The Institutional Dynamics of International Political Orders. International Organization, v. 52, n. 4, 1998, p. 943 - 969.

MATIJASCIC, Vanessa Braga. Haiti: Uma História de Instabilidade Política. In: XX Encontro Regional de História: História e Liberdade, 2010. Franca: ANPUH.

MEARSHEIMER, John. The Tragedy of Great Power Politics. New York: W. W. Norton \& Company, 2001.

MEIERHENRICH, Jens. Perpetual War: A Pragmatic Sketch. Humans Rights Quarterly, v. 29, n. 3, 2007, p. 631-673.

MENDONÇA, Marcos Venicio. Brasil no Haiti: um caso de sucesso. In: HAMANN, Eduarda; RAMIRES, Carlos. (Orgs). A participação do Brasil na MINUSTAH (2004-2017): percepções, lições e práticas relevantes para futuras missões. Rio de Janeiro: Instituto Igarapé, 2017, p. 58 - 65.

MIRANDA, André Luis Novaes. A pacificação de Bel Air. In: HAMANN, Eduarda; RAMIRES, Carlos. (Orgs). A participação do Brasil na MINUSTAH (2004-2017): percepções, lições e práticas relevantes para futuras missões. Rio de Janeiro: Instituto Igarapé, 2017, p. 51 - 57.

MUGGAH, Robert. Introduction. IN: (Ed). Stabilization Operations, Security and Development. London: Routledge, 2013. p. 1 - 14.

MUÑOZ, Enara. A Cooperação Sul-Sul do Brasil com a África. Caderno CRH, v. 29, n. 76, 2016, p. $9-12$. 
MURITHI, Tim. The African Union's Transition from Non-Intervention to NonIndifference: An Ad Hoc Approach to the Responsibility to Protect?. Independent Publishers Group, n. 1, 2009, p. 90 - 106.

NAKANO, Ryoko; PRANTL, Jochen. Global Norm Diffusion in East Asia: How China and Japan Implement the Responsibility to Protect. International Relations, v. 25 , n. 2, 2011, p. $204-223$.

NAVARI, Cornelia. The concept of practice in the English School. European Journal of International Relations, v. 17, n. 4, 2011, p. 611 - 630.

NIEMANN, Holger; SCHILLINGER, Henrik. Contestantion 'all the way down'? The grammar of contestation in norm research. Review of International Studies, v. 43, n. 1,2016 , p. $29-49$.

O’NEAL, John; RUSSETT, Bruce. Democracy, Interdependence and International Organizations. New York: W. W. Norton \& Company, 2001.

ONUF, Nicholas. World of Our Making: Rules and rule in Social Theory and International Relations. Columbia: University of South Carolina Press, 1989.

PARIS, Roland; SISK, Timothy. Introduction: Understanding the contradictions of postwar statebuilding. In: PARIS, Roland; SISK, Timothy. (Eds). The Dilemmas of Statebuilding: Confronting the contradictions of postwar peace operations. London: Routledge, 2009, p. 1 - 20.

PARIS, Roland. At War's End: Building peace after civil conflict. Cambridge: Cambridge University Press, 2004.

PAYNE, Rodger. Persuasion, Frames and Norm Construction. European Journal of International Relations, v. 7, n. 1, 2001, p. $37-61$.

PIMENTEL, Vanderson. Brasil e Haiti já se enfrentaram 'pela paz'. Estadão, São Paulo, 8 jun. 2016.

RICHMOND, Oliver. Failed Statebuilding: Intervention, the state, and the dynamics of peace formation. New Haven: Yale University Press, 2014.

RISSE, Thomas; SIKKINK, Kathryn. The socialization of international human rights norms into domestic practices: introduction. In: RISSE, Thomas; ROPP, Stephen; SIKKINK, Kathryn (Eds). The Power of Human Rigths: International norms and domestic change. New York: Cambridge University Press, 1999, p. 138.

RIZZI, Kamilla. A instabilidade contínua na Guiné-Bissau. Meridiano 47, n. 117, 2010, p. $23-26$. 
ROBINSON, Neil. State-building and international politics: The emergence of a "new" problem and agenda. In: HEHIR, Aidan; ROBINSON, Neil. (Eds). StateBuilding: Theory and practice. London: Routledge, 2007, p. $1-28$.

ROQUE, Sílvia. Peacebuilding In Guinea-Bissau: A Critical Approach. Oslo: Norwegian Peacebuilding Centre, 2009.

RUGGIE, John. Constructing the World Polity: Essays on International Institutionalization. New York: Routledge, 1998.

SALTER, Mark; SEWELL, James. Panarchy and Other Norms for Global Governance: Boutros-Ghali, Rosenau and Beyond. Global Governance, v. 1, n. 3, 1995, p. 373-382.

SARDENBERG, Ronaldo Mota. Prefácio. In: HAMANN, Eduarda; RAMIRES, Carlos. (Orgs). A participação do Brasil na MINUSTAH (2004-2017): percepções, lições e práticas relevantes para futuras missões. Rio de Janeiro: Instituto Igarapé, 2017 , p. $3-4$.

SEITENFUS, Ricardo Antônio Silva. Haiti: A soberania dos ditadores. Porto Alegre: SóLivros, 1994.

SILVA, Adriel Felipe de Alcântara. Brasil, ONU e Haiti: Imagens Sobre a Crise Haitiana Entre 2004 e 2014. 2016. Dissertação (Mestrado em História) - Centro de Ciências Humanas, Letras e Artes, Universidade Federal do Rio Grande do Norte, Natal.

SLAUGHTER, Anne-Marie. A New World Order. Princeton: Princeton University Press, 2004.

SOLINGEN, Etel. Of Dominoes and Firewalls: The Domestic, Regional, and Global Politics of International Diffusion. International Studies Quarterly, v. 56, 2012 , p. $631-644$.

SOUZA, Natalye Gembatituk de. Brasil: uma visão alternativa à falência estatal?. 2014. Dissertação (Mestrado em Relações Internacionais) - Instituto de Relações Internacionais, Pontifícia Universidade Católica do Rio de Janeiro, Rio de Janeiro.

STOLTE, Christina. Brazil's Africa Strategy: Role conception and the drive for international status. New York: Palgrave Macmillan, 2015.

STUENKEL, Oliver; TAYLOR, Matthew. Brazil on the Global Stage: Origins and Consequences of Brazil's Challenge to the Global Liberal Order. In: STUENKEL, Oliver; TAYLOR, Matthew (Eds.). Brazil on the Global Stage: Power, Ideas, and the Liberal International Order. New York: Palgrave Macmillan, 2015, p. 1 - 16. 
TADJBAKHSH, Shahrbanou. Open societies, open markets: assumptions and illusions. In: TADJBAKHSH, Shahrbanou. (Ed). Rethinking the Liberal Peace: External models and local alternatives. London: Routledge, 2001, p. $19-36$.

TOM, Patrick. Liberal Peace and Post-Conflict Peacebuilding in Africa. London: Palgrave Macmillan, 2017.

TOURINHO, Marcos. For Liberalism without Hegemony: Brazil and the Rule of Non-Intervention. In: STUENKEL, Oliver; TAYLOR, Matthew (Eds.). Brazil on the Global Stage: Power, Ideas, and the Liberal International Order. New York: Palgrave Macmillan, 2015, p. 79 - 94.

VALLER FILHO, Wladimir. O Brasil e a Crise Haitiana: A Cooperação Técnica Como Instrumento de Solidariedade e de Ação Diplomática. Brasília: Fundação Alexandre de Gusmão, 2007.

VERENHITACH, Gabriela Daou. A MINUSTAH e a Política Externa Brasileira: Motivações e Consequências. 2008. Dissertação (Mestrado em Relações Internacionais) - Centro de Ciências Sociais e Humanas, Universidade Federal de Santa Maria, Santa Maria.

VIEIRA NETO, Florian Peixoto. Epopeia militar brasileira no Haiti. In: In: HAMANN, Eduarda; RAMIRES, Carlos. (Orgs). A participação do Brasil na MINUSTAH (2004-2017): percepções, lições e práticas relevantes para futuras missões. Rio de Janeiro: Instituto Igarapé, 2017, p. 16 - 23.

WALTZ, Kenneth. Man, the State and War: A theoretical analysis. New York: Columbia University Press, 2001.

WALTZ, Kenneth. Theory of International Politics. London: Addison-Wesley Publishing Company, 1979.

WENDT, Alexander. Social Theory of International Politics. Cambridge: Cambridge University Press, 1999.

WIENER, Antje. A Theory of Contestation. Hamburg: Springer, 2014.

WIENER, Antje. Contested Compliance: Interventions on the Normative Structure of World Politics. European Journal of International Relations, v. 10, n. 2, 2004, p. $189-234$.

WIENER, Antje. Contested Meanings of Norms: A Research Framework. Comparative European Politics, v. 5, 2007a, p. 1 - 17.

WIENER, Antje. The Dual Quality of Norms and Governance beyond the State: Sociological and Normative Approaches to "Interaction". Critical Review of International Social and Political Philosophy, v. 10, n. 1, 2007b, p. 47 - 69. 
WINSTON, Carla. Norm structure, diffusion, and evolution: A conceptual approach. European Journal of International Relations, v. 0, n. 0 2017, p. 1 - 24.

WOOLLACOTT, John. A luta pela libertação nacional na Guiné-Bissau e a revolução em Portugal. Análise Social, v. 19, n. 3, p. 1131 - 1155. 